\title{
DESCOPERIRI FUNERARE ÎN SITUL ARHEOLOGIC DE LA NUFĂRU, JUD. TULCEA
}

\author{
Oana Damian, Gheorghe Mănucu-Adameşteanu, \\ Mihai Vasile, Aurel Stănică, Anca Bănăseanu, \\ Andra Samson, Gabriel Vasile
}

\section{Découvertes funéraires à Nufăru, dép. de Tulcea}

Les auteurs présentent les résultats des fouilles pratiquées depuis 1978 dans un site archéologique situé dans le Nord de la Dobroudja, entièrement recouvert par un village contemporain. L'étude analyse les complexes funéraires répandus dans la localité, appartenant aux différentes nécropoles attribuées à l'époque romaine byzantine, byzantine et moderne. Le catalogue des complexes funéraires présentés contient des données archéologiques et anthropologiques, organisées selon le critère topographique, concernant les tombes d'inhumation découvertes à Nufăru, dans les rues du village ou sur des différentes propriétés, surtout comme le résultat des fouilles préventives.

L'analyse des 162 complexes funéraires a permis une séparation des sépultures du point de vue chronologique dans trois groupes : $\mathrm{IV}^{\mathrm{e}}-\mathrm{VI}{ }^{\mathrm{e}}$ siècles $(10), \mathrm{X}^{\mathrm{e}}-\mathrm{XIII}{ }^{\mathrm{e}}$ siècles (54), XVIII ${ }^{\mathrm{e}}-\mathrm{XIX}{ }^{\mathrm{e}}$ siècles (98). On a utilisé comme critère de datation l'emplacement des complexes du point de vue stratigraphique, les relations entre eux, les pièces du mobilier funéraire qui permettent une certaine attribution historique, découvertes seulement dans 17 sépultures, et les analogies avec d'autres nécropoles datées plus exactement.

Les découvertes appartenant à l'époque romaine byzantine (catalogue, les tombes 31, 34, 37-41, 44, $62,69)$ sont groupées dans la rue Bisericii (de l'Eglise), superposées par des fosses ménagères médiévales et représentées par des squelettes orientés O-E, disposés sur un côté, le bras droit au long du corps et le bras gauche sur le bassin, sans mobilier funéraire, semblables aux découvertes faites à Noviodunum-Isaccea, Beroe-Ostrov, Histria, Tomis-Constanța, Callatis-Mangalia. Il s'agit, peut être, d'une partie de la nécropole de l'agglomération humaine identifiée sur la partie nord du promontoire de Nufăru.

L'époque byzantine est représentée du point de vue funéraire par des tombes isolées et par des groupes de sépultures situés en dehors de l'enceinte byzantine (catalogue, les tombes 1, 3-23, 29, 32, 35, 47-57, 65, 67, 92-96, 98-103, 107-109, 125). La recherche programmée en train de déroulement dans la partie nord du promontoire a identifié une nécropole dont 265 complexes ont été fouillés déjà, mais qui ne constituent pas le sujet de cette étude. Sur le côté ouest de la forteresse byzantine il y a seulement une zone funéraire identifiée en 1980 par des tombes contenant comme mobilier des bracelets en verre. Sur le côté est de la cité, des complexes funéraires d'inhumation ont été enregistrés dans la rue Turnului, tout près du dispensaire humain ( 2 tombes fouillés en 1983 et seulement une en 2005), datés peut être à la fin du $\mathrm{X}^{\mathrm{e}}$ siècle et dans la première moitié du XI siècle, en face du bâtiment de l'école rurale (12 tombes) et sur la rue C-tin. Dobrogeanu Gherea, sur la propriété D. Ducica (6 sépultures), datant probablement aux XII et XIII ${ }^{\mathrm{e}}$ siècles. Sur le côté sud de la courtine byzantine, les découvertes funéraires sont plus nombreuses, notamment dans la rue Bisericii. Les fouilles ont documenté quelques concentrations: sur la propriété N. Drăgan (11 tombes), datées aux $\mathrm{XII}^{\mathrm{e}}$ et $\mathrm{XIII}^{\mathrm{e}}$ siècles, sur les deux côtés du mur d'enceinte sud et tout près du rempart (17 tombes), datées du $\mathrm{XI}^{\mathrm{e}}$ siècle. Soit des découvertes isolées, soit des groupements des sépultures constituant des cimetières, les complexes funéraires analysés ou seulement récupérés dans le site archéologique de Nufăru sont des tombes d'inhumation, planes, rangées en ligne, dans des fosses simples ou avec des cercueils en bois ou des coffres en pierre. Les squelettes ont été déposés en décubitus dorsal, 
les bras dans différentes positions : sur les épaules, sur la poitrine, sur l'abdomen, sur le bassin, au long du corps. Le mobilier funéraire est documenté seulement dans 11 sépultures (catalogue, les tombes 19, $21,29,48,57,65,67,98,99,101,125)$, étant représenté par des bijoux et des monnaies. Les sépultures et les nécropoles médiévales fouillées à Nufăru font partie, du point du vue du rite et du rituel, d'une série de cimetières datant de la période des $\mathrm{X}^{\mathrm{e}}-\mathrm{XIV}^{\mathrm{e}}$ siècles, identifiées en Dobroudja à Dinogetia-Garvăn, Noviodunum-Isaccea, Troesmis-Turcoaia, Enisala-,Palancă”, Ostrov, dép. de Tulcea, à Capidava, Constanța, Histria, Bugeac, Păcuiul lui Soare, Dervent et, également, dans la Bulgarie du Nord-Est, à Silistra, Odărtzi, Garvăn, Cavarna et Caliacra.

A Nufăru il y a au moins deux cimetières d'époque moderne, datés aux XVIII ${ }^{\mathrm{e}}$ et $\mathrm{XIX}^{\mathrm{e}}$ siècles (catalogue, les tombes 2, 24-28, 30, 33, 36, 42-43, 45-46, 58-91, 97, 104-106, 110-124, 126-162). L'un d'entre eux (représenté par 62 complexes) est placé dans la zone marquée par les rues Bisericii, C-tin. Dobrogeanu Gherea et Rapsodiei, dans le voisinage du Foyer culturel, sur les deux cotés du bâtiment, en couvrant environ 200 m (des tombes fouillées en 1980-1981 et en 2006). Il s'agit des tombes d'inhumation, aux squelettes en décubitus dorsal, orientés O-E, dans des cercueils en bois, les bras dans différentes positions - sur la poitrine, sur l'abdomen, sur le bassin et au long du corps, avec des bijoux, des accessoires vestimentaires et des monnaies ottomanes comme mobilier (catalogue, les tombes 25-26, 68, 74-75, 78). Des sépultures modernes ont été identifiées également dans la partie sud-est du village, dans le périmètre des rues Zimbrului, Aurel Vlaicu, Miron Costin et Trandafirilor (36 complexes), avec des mêmes caractéristiques, formant un autre noyau funéraire, presque contemporain à celui présenté déjà, éventuellement plus tardif, mais difficile à dater sans aucun élément chronologique définitoire.

La périodisation des nécropoles fouillées à Nufăru, proposée par le collectif de recherche au début des fouilles, pendant les années 80 du siècle passé, a été partiellement confirmée par la recherche archéologique qui a suivi. Pour la période comprise entre la fin du $\mathrm{X}^{\mathrm{e}}$ siècle et la première moitié du $\mathrm{XI}^{\mathrm{e}}$ siècle on peut suggérer seulement un groupement des complexes funéraires dans le voisinage du mur d'enceinte, surtout près de la tour de la courtine est. Pour la période de la deuxième moitié du XI siècle jusqu'au milieu du XIII ${ }^{\mathrm{e}}$ siècle — le moment de la fin de l'établissement médiéval de Nufăru les fouilles programmées déroulées dans la partie nord du promontoire ont beaucoup enrichi les données scientifiques. Les fouilles pratiquées sur les propriétés Drăgan et Ducica ont suggéré l'existence d'une nécropole datant au cours des XII $-\mathrm{e} I \mathrm{II}^{\mathrm{e}}$ siècles sur les côtés est et sud de la courtine byzantine. Les sépultures byzantines du côté sud de la forteresse se mélangent avec des complexes datant aux $\mathrm{XVIII}^{\mathrm{e}}$ et $\mathrm{XIX}^{\mathrm{e}}$ siècles. Les fouilles pratiquées à l'ouest de la courtine byzantine n'ont pas identifié des tombes et celles déroulées dans la partie sud du village n'ont pas confirmé l'existence d'une nécropole datée aux $\mathrm{X}^{\mathrm{e}}$ et $\mathrm{XI}^{\mathrm{e}}$ siècles, mais ont relevé la présence d'un cimetière plutôt moderne $\left(\mathrm{XVIII}^{\mathrm{e}}-\mathrm{XIX} \mathrm{e}^{\mathrm{e}}\right.$ siècles$)$.

L'étude analyse du point de vue anthropologique seulement 118 complexes funéraires, en identifiant 163 individus. Le paramètre sexe a été déterminé pour 109 individus $(66,87 \%)$, dont 60 $(55,04 \%$ 1) représentent le sexe féminin et 49 (44,95\%) le sexe masculin. 47 individus $(28,83 \%)$, sont des enfants. Les catégories d'âge dont appartiennent les individus sont les suivantes: infans I (3320,24\%), infans II (9-5,52\%), juvenis (3-1,84\%), adultus (5-3,06\%), maturus I (14-8,58\%), maturus II (21-12,88\%) et senilis I (33-20,24\%). Pour 45 cas (27,60\%), les catégories d'âge sont incertaines: infans I / infans II (4-2,45\%), infans II / juvenis (1-0,61\%), juvenis / adultus (4-2,45\%), juvenis / adulte (8-4,90\%), adultus / adulte (21-12,88\%) ou adultes (7-4,29\%). L'estimation de la taille a été faite pour 78 cas $(47,56 \%)$, pour les individus adultes $(65-83,33 \%)$ et pour les enfants $(13-16,66 \%)$. Pour les deux sexes, les tailles sont petites (16-24,61\%), en dessous de la moyenne (20-30,76\%), moyennes (9-13,84\%), en dessus de la moyenne (13-20\%) et grandes (7-10,76\%). En ce qui concerne le squelette crânien et postcrânien, l'étude a relevé quelques caractères non métriques. On remarque la prédominance des crânes dolichocrânes (= allongés, 5), méso crânes (= moyens, 7) ou brachy crânes (= arrondis, 6). Du point de vue pathologique, on a signalé la présence des caries (19 individus), des édentations/édentassions (12) et des exostoses (8), maladies qui ont marqué également les femmes et les hommes; on a identifié hyperostoza porotica sur le squelette d'un enfant. On a aussi signalé des 
discontinuités osseuses, le résultat probable des fractures curies $(2$ cas $)$ et la présence du phénomène de la pseudoplagiocéphalie.

Mots clef: complexe funéraire, tombe, inhumation, époque romaine byzantine, époque byzantine, époque moderne

Cuvinte cheie: complex funerar, mormânt, inhumație, epoca romano-bizantină, epoca bizantină, epoca modernă.

Investigațiile arheologice au pus în evidență pe linia Dunării, pe malul drept al brațului Sf. Gheorghe, la circa $12 \mathrm{~km}$ aval de Tulcea, în teritoriul intravilan al satului Nufăru, existenţa unei fortificații ridicate a fundamentis de către Imperiul bizantin în ultimul sfert al secolului al X-lea, odată cu recucerirea de către acesta a regiunii Dunării de Jos, transformată în cursul secolului al XI-lea în aşezare de tip urban, cu structuri de locuire şi complexe funerare înregistrate stratigrafic până la mijlocul secolului al XIII-lea. Prin cercetarea, în proporții variabile, între 1977 şi 2007 a peste 30 de zone de pe teritoriul satului, s-au putut obține informații privind nu numai epoca medio-bizantină, ci şi referitor la viețuirea pre- şi protoistorică, antică şi chiar modernă ${ }^{1}$.

Suprapunerea în totalitate a sitului arheologic de către aşezarea contemporană (fig. 1) a făcut ca informația arheologică să fie obținută de către colectivul de cercetare a sitului $^{2}$ atât prin intermediul cercetării

1 Pentru o informare generală privind situația arheologică din intravilanul localității Nufăru vezi Damian et alii 2003a, 237-266, cu bibliografia anterioară; Damian et alii 2007a.

2 Din componenţa colectivului arheologic, de-a lungul celor trei decenii de cercetări, au făcut/fac parte, regretata cercetătoare Silvia Baraschi (Institutul de Arheologie „Vasile Pârvan”, responsabilul ştiințific al șantierului în perioada 1978-1990), Neculai Moghior (Muzeul Militar Central), Gh. Mănucu-Adameşteanu (Muzeul Deltei Dunării Tulcea, actualmente la Muzeul Municipiului Bucureşti), Oana Damian (IAB, responsabilul actual al santierului), Corneliu Andonie (Muzeul Militar Național), Paul Damian (Muzeul Național de Istorie a României), Mihai Vasile (MNIR), Aurel Stănică (Institutul de Cercetări Eco-Muzeale Tulcea), Anca Bănăseanu, Andra Samson (MNIR). Cercetarea complexelor funerare a fost unul dintre obiectivele care, pe parcursul campaniilor de activitate arheologică la Nufăru, a mobilizat întregul colectiv al acestui şantier. La programate, desfăşurate în general în zonele publice, libere de construcții, cât şi al unor investigații preventive în zonele urmând a fi afectate de activităţi constructive moderne, la care se adaugă descoperiri întâmplătoare sau recuperări de materiale şi situațiii ${ }^{3}$ (fig. 2).

În ceea ce privește informația referitoare la necropolele de inhumație înregistrate pe teritoriul localităţii Nufăru ${ }^{4}$ (fig. 3), cercetările arheologice au dezvăluit prezența mai multor nuclee cimiteriale aparținând locuitorilor aşezării medievale, care se interferează pe alocuri cu morminte moderne (secolele XVIII-XIX), precum şi existența unui orizont funerar ce poate fi atribuit, eventual, epocii romano-bizantine ${ }^{5}$. Precizăm că studiul complexelor funerare a fost determinat uneori de cercetarea fortificaţiei bizantine, mormintele suprapunând sau aflându-se în proximitatea elementelor ei cazul turnului romano-bizantin din punctul Piatră, al zidului de incintă sudic cercetat pe str. Bisericii, al ansamblului de ziduri din curtea dispensarului uman sau al instalației portuare şi al curtinei nordice din punctul

cercetarea complexelor funerare în campania 2006 a mai participat şi Irina Ene (MNIR).

${ }^{3}$ Punctele cercetate arheologic au fost numite fie după aspectul topografic, fie în funcție de obiectivul cel mai apropiat, fie după proprietarul terenului respectiv, fie după monumentul studiat, fiind enumerate în ordinea cronologică a desfăşurării campaniilor. Având în vedere faptul că recent străzile localității au fost denumite, s-a procedat la corelarea numelor punctelor în care s-au efectuat săpături arheologice cu amplasamentul lor stradal.

${ }^{4}$ Pentru unicul mormânt de incinerație descoperit până în prezent, aparținând probabil epocii elenistice, vezi Damian et alii 2007a, n. 57.

${ }^{5}$ Pentru descoperirile romane şi romano-bizantine de la Nufăru vezi Mănucu-Adameşteanu et alii 2007, 375398. 
Trecere bac. În alte cazuri, complexe funerare au apărut fie în sondaje determinate de descoperirea unor materiale arheologice ${ }^{6}$, fie cu ocazia intervențiilor legate de diverse amenajări, indiferent că a fost vorba de lucrările ample de alimentare cu apă a satului — realizate în 1981 şi 2006 — sau de bazine vidanjabile pentru locuitori, fie, fortuit, în cazul intemperiilor care au afectat starea drumurilor sătești. Ca atare, informația este de multe ori lacunară, în condițiile imposibilității continuării cercetării în acelaşi loc ori verificării unor situaţii sau a intervenţiei tardive a arheologului, redus la condiția de recuperator de materiale, dar nu şi de informație.

Catalogul prezentat în acest studiu, reunind deopotrivă informații arheologice şi antropologice, conține complexele funerare descoperite pe teritoriul satului Nufăru cu ocazia cercetărilor, cu precădere preventive, desfăşurate în diverse puncte, pe proprietăți particulare ori pe străzile localității. Mențiunile referitoare la descoperiri arheologice anterioare anului $2000 \mathrm{nu}$ sunt întotdeauna însoțite de referiri la materialul osteologic, acesta fiind doar parțial accesibil. Catalogul complexelor funerare a fost alcătuit, însoțit de observațiile antropologice datorate lui Gabriel Vasile ${ }^{7}$, după criteriul mormânt de inhumație, indiferent de apartenența cronologică a complexelor, tratată separat, iar ordonarea a fost dictată de situația topografică. Pentru descoperirile din anii '80, a fost folosită informația oferită de către Gh. Mănucu-Adameşteanu, precum şi documentația cercetărilor inedite ale Silviei Baraschi. Pentru descoperirile funerare efectuate în campaniile 1999, 2001, 2003, 2005, 2007, documentarea s-a putut realiza integral, în timp ce desfăşurarea proiectului de alimentare cu apă din 2006, a determinat, prin forța lucrurilor, nu numai cercetarea

\footnotetext{
${ }^{6}$ Cazul depozitului de vase sferoconice descoperit pe proprietatea locuitorului Nicolae Drăgan, situată pe str. Bisericii (Mănucu-Adameşteanu 1983, 470-473; Mănucu-Adameşteanu 1984a, 363-374).

${ }^{7}$ Antropolog în cadrul Centrului Național de Cercetări Pluridisciplinare - MNIR.
}

complexelor, ci şi, uneori, doar adunarea osemintelor. În funcție de gradul de recuperare a informației legate de aceste complexe funerare, ele au fost: cercetate complet, prin deschiderea de casete şi analizarea lor din punct de vedere arheologic şi antropologic; cercetate parţial, prin înregistrarea pe malurile şanţurilor trasate pentru introducerea conductelor de alimentare cu apă $\breve{8}^{8}$ şi extragerea doar a unor părți accesibile de schelet, ceea ce a permis puține observații legate de ritualul funerar sau de ordin antropologic; recuperate din cupa excavatorului sau din pământul răscolit mecanic ori deranjate de curiozitatea localnicilor, fiind posibile doar o serie de observații antropologice.

Elemente de rit şi ritual. Probleme de topografie şi cronologie a zonelor cimiteriale

Cele 162 de complexe funerare înregistrate au putut fi repartizate în 3 mari grupe în funcție de încadrarea lor cronologică: cele aparţinând epocii romano-bizantine (secolele IV-VI) - 10, cele aparținând epocii medio-bizantine (secolele X-XIII) - 54 şi cele aparținând epocii moderne (secolele XVIII-XIX) - 98. Precizăm că această încadrare cronologică conţine o mare doză de probabilitate $^{9}$, având în vedere faptul că, dintre cele 162 de complexe invocate, doar 17 conțin inventare funerare ce permit atribuirea mormintelor unei anumite epoci istorice (catalog, pozițiile 19, 21, 25-26, 29, 48, 65, 67$68,70,74,75,78,98-99,101,125)$. Într-o serie de cazuri au fost aplicate criteriul poziției stratigrafice şi cel al relaţiei dintre complexe ori al analogiei cu elemente de ritual datate în alte necropole. Au fost şi situaţii în care propunerea încadrării cronologice s-a făcut doar prin excludere, în acest caz formula utilizată în catalog fiind aceea de ,încadrare cronologică probabilă".

\footnotetext{
${ }^{8}$ Vezi, de exemplu, Damian et alii 2007a, fig. 12.

${ }^{9} \mathrm{Cel}$ puţin pentru 91 de cazuri dintre cele prezentate.
} 
Descoperirile funerare pe care suntem înclinați să le atribuim epocii romanobizantine provin din campania 2006, de pe str. Bisericii, la est de proprietatea cu nr. 98, fiind reprezentate de un grup de 6 morminte de inhumație, dispuse la rând, morminte care, prin suprapunerea lor de către complexe menajere medievale, amplasarea în pământul galben nisipos, elemente de ritual specifice aşezarea pe o parte a defuncților - şi analogii cu situații documentate în necropolele de la Noviodunum-Isaccea ${ }^{10}$, Beroe-Ostrov ${ }^{11}$, Enisala-La Peşteră ${ }^{12}$, Histria ${ }^{13}$, TomisConstanța $^{14}$, Callatis-Mangalia ${ }^{15}$, pot fi încadrate în secolele IV-VI. Se poate avansa ideea că este vorba de un segment aparținând necropolei aşezării romano-bizantine documentate în capătul nordic cel mai înalt al promontoriului nufărean, în zona $\mathrm{km}$ fluvial 104 (punctul Piatră şi fosta proprietate Butuza) ${ }^{16}$ (catalog, pozițiile: $34,37,38,39$, 40, 41; fig. 4-5; 6/1-7). Aceluiaşi grup de morminte credem că i se poate adăuga şi descoperirea funerară făcută în $2007 \mathrm{cu}$ ocazia unei cercetări preventive desfăşurate pe proprietatea A. Husein, amplasată tot pe str. Bisericii, la nr. $98^{17}$ (catalog, poziția 44, fig. 5, 6/8), precum şi, eventual, o descoperire

\footnotetext{
${ }^{10}$ Baumann et alii 2006, 186.

11 Petre 1987, pl. 99.

12 Iacob et alii 2007, 147.

${ }^{13}$ Hamparțumian 1971, 211.

14 Lungu, Chera-Mărgineanu 1982, 181; CheraMărgineanu, Lungu 1983, 220.

15 Preda 1980, 93.

16 Mănucu-Adameșteanu et alii 2007, 376-378, n. 1114. Mai trebuie precizat că la nord de acest grupaj de morminte, în dreptul proprietății cu nr. 96 situată pe str. Bisericii, în şanţurile practicate pentru realizarea alimentării cu apă a localității Nufăru, atât în 1981 (cercetări inedite Gh. Mănucu-Adameşteanu), cât şi în 2006 (Damian et alii 2007a, fig. 12) au fost identificate vestigii ale unei constructii documentate prin foarte mult material tegular, ce ar putea sugera prezența unui edificiu de cult. Din păcate, dimensiunile foarte reduse ale şanţurilor săpate pentru introducerea conductelor de apă şi imposibilitatea extinderii săpăturilor nu au permis obtinerea mai multor informatii.

17 Ar merita menționat faptul că în imediata apropiere a acestei descoperiri, pe proprietatea aparținând lui A. Husein, a fost găsită în 2005 o monedă emisă în vremea împăratului Iustinian, a.527-537 (Mănucu-Adameşteanu et alii 2007, 377, 392, catalog, nr. 59).
}

întâmplătoare făcută în 1999 tot pe str. Bisericii, în dreptul proprietății cu nr. 102 (catalog, poziția 31). În cazul celor 8 complexe funerare în discuție remarcăm dispunerea scheletului în decubit ventral întrun caz (catalog, poziţia 39), în decubit dorsal în 3 cazuri (catalog, pozițiile $31,40,44$ ) şi aşezarea scheletului pe partea dreaptă în 4 cazuri (catalog, pozițiile 34, 37, 38, 41). Remarcăm totodată, în ceea ce priveşte poziția antebrațelor, faptul că dreptul este întotdeauna întins pe lângă corp, iar stângul, atunci când prezența lui a fost înregistrată, este sprijinit pe bazin. Se impune totodată precizarea absenței oricărui element de inventar.

În ceea ce priveşte epoca mediobizantină, complexele funerare de la Nufăru, identificate, cercetate parțial sau încă în curs de cercetare, cu şanse de finalizare în viitorul apropiat, constau în descoperiri de morminte izolate şi de necropole amplasate extra muros, pe toate laturile fortificatiei bizantine.

Zona cea mai bogată din punctul de vedere al descoperirilor funerare este zona nordică a promontoriului nufărean, cu cele două puncte cercetate, Piatră, în dreptul bornei kilometrice fluviale $104^{18}$ şi proprietatea Enache Şinghi = punctul Trecere $b a c^{19}$. Complexele funerare provenite din cercetările programate desfăşurate în aceste două puncte, conturând o singură necropolă, vor constitui subiectul unui studiu viitor, realizabil după încheierea cercetărilor în ultimul punct menționat.

Pe latura de vest a cetății se cunoaşte doar un singur punct cu descoperiri funerare, în vecinătatea complexului de cuptoare

\footnotetext{
18 Baraschi, Moghior 1979, 189; Baraschi, Moghior 1980, 125-126; Baraschi, Moghior 1984-1985, 145; Damian 1993, 81-113; cercetări inedite 1998. În campaniile 1978-1979, 1985-1988, 1998 au fost descoperite 88 de morminte.

19 Damian et alii 2000, 67-68; Damian et alii 2001, 164; Damian et alii 2002, 216-217; Damian et alii 2003b, 213-214; Damian et alii 2005, 245-246, Damian et alii 2006, 237-238; Damian et alii 2007b, 240-243. În campaniile 1999-2002, 2004-2007 au fost descoperite 177 de morminte.
} 
cercetat în 1982 (catalog, poziția 1), în pofida sondajelor efectuate în 4 puncte în $2002^{20}$, respectiv $2005^{21}$, precum şi a supravegherii arheologice realizate în 2006 pe str. Eternităţii. În 1982 a fost înregistrată prezența a numeroase schelete, unele cu brățări de sticlă, databile în secolele X-XI, deranjate de intervenții moderne ${ }^{22}$.

Pe latura de est a cetății au fost înregistrate complexe funerare în 4 puncte. Unul dintre aceste puncte, cercetat în 1982, se află pe str. Turnului, în punctul Şcoală, în dreptul proprietăţii Chiselencu, fiind descoperite 12 morminte, parțial cercetate, unele documentate doar prin cranii, altele pătrunzând în cea mai mare parte în malurile secțiunii, lipsite de inventar funerar, datate stratigrafic într-o epocă posterioară secolului al XI-lea $^{23}$ (catalog, pozițiile 3-14, fig. 7-8/1-5). Cercetările preventive desfăşurate în 2006 , cu ocazia introducerii conductelor pentru alimentarea cu apă a localităţii Nufăru, au documentat pe str. Turnului prezența unei masive depuneri ocupationale moderne, ceea ce ar sugera faptul că mormintele descoperite în 1982 pe aceeaşi stradă ar putea aparține, eventual, unui orizont cronologic aparținând secolelor XII-XIII, având în vedere şi descoperirile funerare făcute în zonă în perioada următoare ${ }^{24}$. Pe aceeaşi stradă a Turnului, în curtea dispensarului uman, în 1983, în Secțiunea 1, cea mai estică dintre cele practicate în acea zonă, au fost descoperite 2 morminte, dintre care unul cu protecție de piatră $^{25}$ (catalog, pozițiile 15-16; fig. 9). Într-o casetă practicată în 2005 pe proprietatea Popa, amplasată tot pe str. Turnului, la nr. 199, în imediata vecinătate a zidului de incintă cu turn

\footnotetext{
${ }^{20}$ Damian et alii 2003b, 215-216 - proprietatea I. Rubanschi.

${ }^{21}$ Damian et alii 2006, 238 - proprietățile S.C. Soliana S.R.L., Paraschiv şi Hanganu.

22 Baraschi, Moghior 1984-1985, 149-150, n. 11; Mănucu-Adameșteanu 1991a, 515; MănucuAdameşteanu 1998, 82.

${ }^{23}$ Baraschi, Moghior 1984-1985, 149.

${ }^{24}$ Este cazul descoperirilor făcute în 2005 , la sud-est de punctul cercetat, pe proprietatea Ducica.

${ }^{25}$ Cercetări inedite Silvia Baraschi.
}

din curtea dispensarului uman, a fost descoperit un mormânt, în nivelul reprezentat de un strat de pământ cenuşiu gălbui databil în secolul al XI-lea, suprapus de locuirea din secolele XII$\mathrm{XIII}^{26}$ (catalog, poziția 17; fig. 8/6; 9). Prezența unei casete de piatră la unul dintre mormintele săpate în curtea dispensarului, amenajare funerară încadrabilă în intervalul cuprins între sfârşitul secolului al X-lea şi mijlocul secolului al XI-lea, precum şi poziţia stratigrafică a mormântului din caseta de pe proprietatea Popa, au sugerat faptul că aceste 3 complexe funerare ar putea aparține unei necropole amenajate în secolul al XI-lea la est de zidul de incintă al cetății bizantine. Pe proprietatea Ducica, situată la sud de şcoală, pe str. C-tin. Dobrogeanu Gherea, tot în campania 2005 au fost descoperite 6 morminte (catalog, pozițiile 18-23; fig. 10-11), de inhumație, în decubit dorsal, conţinând 4 schelete bine conservate, 3 de adulți (catalog, pozițiile 18-20) şi unul de copil (catalog, poziția 21), unul incomplet (catalog, poziția 22) şi unul parțial cercetat (catalog, poziția 23), ce pătrunde în malul sudic al S 1 Ducica, cu antebraţele în diverse poziții: ambele antebrațe pe bazin (catalog, poziția 20), un antebraț pe bazin şi celălalt pe piept (catalog, pozițiile 18-19), antebrațul stâng pe lângă corp, antebrațul drept absent (catalog, poziția 21); două morminte au avut piese de inventar din bronz - o monedă, un follis din secolul al XIlea (catalog, poziţia 19) şi doi cercei de tip verigă simplă, tot din bronz (catalog, poziția $21)^{27}$. Pe baza observațiilor stratigrafice, pentru depunerile arheologice de pe proprietatea Ducica se poate avansa următoarea cronologie: un prim nivel reprezentat de gropi menajere, care suprapune, distrugând uneori, un nivel de cuptoare, acesta din urmă fiind suprapus de cel al necropolei, toate aceste depuneri părând să acopere perioada cuprinsă între secolul al XIIlea şi prima jumătate a secolului al XIII-lea. Nu s-au înregistrat în această zonă depuneri arheologice aparținând secolelor X-XI. Segmentul de necropolă, care, prin intermediul

\footnotetext{
${ }^{26}$ Damian et alii 2006, 239.

${ }^{27}$ Damian et alii 2006, 238-239.
} 
M 21, suprapune nivelul cuptoarelor, pentru amenajarea vetrelor cărora au fost folosite fragmente ceramice provenind de la vase databile în secolul al XII-lea, se poate data deci într-o perioadă ulterioară acestui secol. În orice caz, moneda datând din secolul al XI-lea din inventarul M $19 \mathrm{nu}$ constituie un argument pentru încadrarea cronologică a mormântului.

Pe latura de sud a cetății, descoperirile funerare sunt mai numeroase, cu precizarea că au fost identificate morminte atât pe strada Bisericii, în zona Căminului cultural şi mai la sud de acesta, cât şi la sud de „zidul-baraj”, situat în punctul Râpă, şi că orizontul înmormântărilor aparținând epocii medievale se interferează cu un altul, încadrabil în secolele XVIII-XIX.

Descoperirile de pe str. Bisericii, din zona Căminului cultural, deci din sudul aşezării medievale, însumând 83 de complexe funerare, au fost prilejuite de mai multe intervenții arheologice.

Un sondaj efectuat de Gh. MănucuAdameşteanu în 1980, pe proprietatea Nicolae Drăgan (str. Bisericii 186), a dezvăluit existența unei necropole documentate prin 11 morminte (catalog, pozitiile 47-57; fig. 12-13), datate la răscrucea secolelor XII-XIII ${ }^{28}$, orientate V-E, cu gropile săpate la adâncimi variind între 0,60 şi $0,90 \mathrm{~m}$, dintre care 5 (catalog, poziţiile $47-$ $48,51-52,55)$ deranjate (M 47-48 au fost afectate de o construcție modernă; groapa M 50 a distrus M 51 şi M 52, ale căror schelete au fost reînhumate, de o parte şi de alta, la picioarele M 50; M 49 a deranjat alte două morminte, din care au fost reînhumate doar craniile, unul de adult şi celălalt de copil, în stânga craniului M 49); M 56 şi M 57 reprezintă două morminte suprapuse, M 56 în sicriu de lemn peste care a fost depus, din zona pieptului în jos, M 57; înhumații au fost depuşi în gropi simple, înregistrându-se prezența sicrielor pentru M 48, M 50 şi M 56; în cazul

28 Mănucu-Adameşteanu 1983, 470-472, fig. 1; Mănucu-Adameşteanu, Mănucu-Adameşteanu 1986, 211-212 şi fig. 1; Mănucu-Adameşteanu 1991a, 516 şi fig. 1; Mănucu-Adameşteanu 1998, 82. scheletelor nederanjate, au fost înregistrate următoarele variante ale poziției antebrațelor: ambele pe bazin - M 50, M 57, ambele pe abdomen - M 49, M 53, ambele pe umăr M 56, dreptul pe umăr, stângul pe piept - M 54; din totalul de 11 morminte, 9 sunt de adulţi, dintre care 2 identificate ca aparținând unor femei (M 48-49) şi 2 de copii $^{29}$; inventarul funerar este reprezentat de verigi simple de bronz, o mărgică de sticlă, două monede - o monedă de billon imitație latină cu modul mare de tip D, din prima jumătate a secolului al XIIIlea - M 48 şi o monedă bizantină schifată emisă la Constantinopol de Isaac II Comnenul 1185-1195 - M 57. Prezența în inventarul mormintelor a celor două mărturii numismatice, sugerează faptul că această necropolă a funcționat în ultima etapă de locuire a aşezării, întreruptă brutal de atacul tătarilor din anul $1242^{30}$.

Acestor morminte li se adaugă o serie de complexe funerare, descoperite, atât în 1981, cât şi în 2006, cu ocazia cercetării zidului de incintă sudic pentru realizarea alimentării cu apă a localității. În campania din 1981 au fost descoperite 6 complexe funerare (str. Bisericii 169, catalog, pozițiile 92-96, 98; fig. 14), dintre care un mormânt de copil cu brățări albastre, încadrabil în secolele $\mathrm{X}-\mathrm{XI}^{31}$. Campania din 2006 a prilejuit descoperirea de o parte şi de cealaltă a zidului de incintă sudic a 11 morminte, dintre care 8 pot aparține secolului al XI-lea (str. Bisericii 93, catalog, pozițiile 99-103, 107-109; fig. 15-16; 17/1-4). Acestora se adaugă încă un complex funerar, identificat în 1999 pe latura vestică a aceleiaşi străzi a Bisericii, la nr. 94, la sud de Căminul cultural, în dreptul proprietății Dobrin, cu

\footnotetext{
${ }^{29}$ In 1980 se considera că este vorba de 10 morminte de adulți, dintre care patru aparținând unor femei, precum şi unul de copil (Mănucu-Adameşteanu 1983, 470471), fapt infirmat însă de analiza antropologică.

30 Mănucu-Adameşteanu 1983, 470-472; MănucuAdameşteanu 1984a, 364; Mănucu-Adameşteanu 1998, 82.

${ }^{31}$ Baraschi, Moghior 1983, 138, Baraschi, Moghior 1984 1985, 149, Mănucu-Adameşteanu, Mănucu-Adameşteanu 1986, 211-212, 214, Mănucu-Adameşteanu 1991a, 516, Mănucu-Adameşteanu 1998, 82.
} 
inventar reprezentat de mărgele de sticlă (catalog, poziția 65), ce ar sugera o încadrare largă, în secolele XI-XIII ${ }^{32}$, precum şi un mormânt doar reperat în 2006, cu ocazia realizării alimentării cu apă, pe str. Bisericii, în dreptul aceleiaşi proprietăți, având un inventar recuperat format din brățări de sticlă (catalog morminte, poziția 67). Gruparea de morminte din preajma zidului de incintă sudic se caracterizează prin aceeaşi orientare V-E, depunere în decubit dorsal, prezența sicrielor (catalog, pozițiile 108-109), varietatea poziționării antebrațelor - pe piept, pe abdomen, pe bazin, pe lângă corp, cu variantele respective: ambele antebrațe pe lângă corp (catalog, poziția 96), dreptul pe abdomen, stângul pe bazin (catalog, poziția 101), dreptul pe bazin, stângul pe piept (catalog, poziţia 108), dreptul pe piept, stângul pe abdomen (catalog, poziția 109) sau doar antebrațul drept pe bazin (catalog, poziția 99). Piesele de inventar descoperite sunt reprezentate de mărgele de sticlă şi chihlimbar (catalog, poziția 101). Din punct de vedere stratigrafic, cercetarea zidului de incintă sudic a documentat, sub amenajarea străzii, prezența unei depuneri cenuşii prăfoase cu pigmenți de mortar, reprezentând nivelul locuirii din secolul al XII-lea-prima jumătate a secolului al XIII-lea, ce suprapune un strat de pământ compact cenuşiu gălbui, gros de maximum $0,20 \mathrm{~m}$, databil în secolul al XI-lea, deasupra nivelului plintei zidului, corespunzând nivelului înhumaților, depunere ce suprapune un strat de pământ brun, cu urme de chirpici din care au fost recoltate materiale preistorice ${ }^{33}$.

În apropiere de zidul de incintă sudic, pe str. Rapsodiei, a fost cercetat în 2002 un mormânt degajat de apele pluviale, cu scheletul în decubit dorsal, orientat V-E, cu antebrațul drept pe piept şi stângul sub claviculă, cu un follis de bronz din secolul al XI-lea drept inventar (catalog, poziţia 125; fig. $15 ; 17 / 5-6$ ).

\footnotetext{
${ }^{32}$ Damian et alii 2000, 68.

${ }^{33}$ Damian et alii 2007a, fig. 10.
}

În sudul aşezării contemporane, la sud de punctul Râpă, au fost descoperite în 1981, într-un şanț pentru aducțiunea apei, două morminte de inhumație (catalog, pozițiile 2829), dintre care unul cu brățări de sticlă albastră, ce completează unele informații despre descoperiri similare mai vechi şi sugerează existența unei necropole ce a funcționat în secolul al XI-lea ${ }^{34}$.

Indiferent dacă reprezintă descoperiri izolate sau constituie adevărate necropole, mormintele cercetate la Nufăru sunt exclusiv de inhumație, cu orientarea scheletelor V-E, plane, dispuse pe şiruri. În general $\mathrm{s}$-a practicat înhumarea individuală. Depunerea scheletelor sa făcut în gropi simple, puțin adânci, de formă rectangulară şi oval alungită, adâncimea la care au fost descoperite scheletele oscilând între $0,10 \mathrm{~m}$ şi $-1,20 \mathrm{~m}$, măsurată de la actualul nivel de călcare; în general, defuncții erau aşezaţi direct pe pământ, dar se înregistrează şi cazuri de folosire a casetei de piatră şi a sicriului, ultimul documentat nu numai prin fragmentele şi amprentele de lemn descoperite, ci şi prin prezența cuielor, a piroanelor şi a scoabelor din fier. Dispunerea scheletelor era în decubit dorsal, cu capul în poziție normală, dar există şi varianta aşezării pe partea dreaptă sau stângă, fără a fi deranjat; picioarele în general erau paralele; observațiile arheologice au permis stabilirea poziției antebrațelor, înregistrându-se mai multe variante, dezvoltate din cinci tipuri principale $\mathrm{cu}$ ambele antebrațe îndoite din coate şi cu palmele aşezate pe umeri, cu ambele încrucişate pe piept, abdomen ori bazin, cu ambele întinse pe lângă corp, cu subvariantele lor. Se înregistrează prezența urmelor de cărbune. Inventarul funerar atribuibil epocii bizantine, documentat în puține morminte (11 - catalog, pozițiile $19,21,29,48,57,65,67,98,99,101$, 125 , la care se adaugă un număr neprecizat de morminte la poziția 1) este reprezentat de piese de podoabă (catalog, pozițiile 21, 29, 48, 65, 67, 98, 99, 101; fig. 28/1-5) şi de monede (catalog,

\footnotetext{
34 Mănucu-Adameșteanu, Mănucu-Adameșteanu 1986, 211-212 şi n. 3; Mănucu-Adameşteanu 1991a, 515; Mănucu-Adameşteanu 1998, 82.
} 
pozițiile 19, 48, 57, 125-fig. 28/6-7), ultimele elemente, în special, servind, împreună cu poziția stratigrafică, şi drept argument de încadrare cronologică (catalog, pozițiile 48,57 , 125). Precizăm însă faptul că există şi situații în care datarea sugerată de monede - cazul follisului din secolul al XI-lea prezent în inventarul mormântului de pe proprietatea Ducica (catalog, poziția 19) — poate fi contrazisă de încadrarea cronologică rezultată din situația stratigrafică, ceea ce pledează pentru ideea utilizării drept obol al lui Charon a oricărei monede, nu neapărat a uneia în circulație ${ }^{35}$. În inventarele mormintelor sunt prezente podoabe ale capului, gâtului şi mâinilor: cercei de tip verigă simplă (catalog, pozițiile $21^{36}$ şi $48^{37}$, fig. 28/1-2), mărgele de sticlă şi chihlimbar (catalog, poziţiile 65 şi 101, fig. 28/3), brățări de sticlă (un număr neprecizat de fragmente descoperite în morminte cercetate în anul $1980^{38}$; catalog, pozițiile $29^{39} ; 67,98$ fig. 28/4-5).

Mormintele şi necropolele medievale identificate în intravilanul localității Nufăru se înscriu în seria necropolelor dobrogene databile în secolele X-XIV, prezentând analogii de rit şi ritual în cimitirele şi grupurile de morminte cercetate în Dobrogea la Dinogetia-Garvăn (în perimetrul cetății, împrejurul bisericii ${ }^{40}$, la sud de cetate ${ }^{41}$, în sectorul „Domus" ${ }^{42}$, în porțiunea de nordvest a incintei cetății ${ }^{43}$, în sectorul A III-IV şi în umplutura turnului $11^{44}$, datate în secolele XI-XII), Noviodunum-Isaccea (în marginea estică a oraşului, în necropola propriu-zisă ${ }^{45}$ şi

\footnotetext{
35 O situație similară poate fi întâlnită şi în cazul complexului funerar cercetat în 2002 pe str. Rapsodiei (catalog, poziția 125), în zonă găsindu-se ulterior doar morminte atribuibile mai degrabă epocii moderne.

${ }^{36}$ Mănucu-Adameșteanu 1983, 472.

${ }^{37}$ Damian et alii 2005, 239.

${ }^{38}$ Mănucu-Adameşteanu 1983, 472.

39 Mănucu-Adameșteanu, Mănucu-Adameșteanu 1986, 214, fig. 4.

40 Ştefan et alii $1967,367-373$.

${ }^{41}$ Barnea 1973, 298-301.

${ }^{42}$ Barnea 1973, 310, 330, fig. 10 (plan).

${ }^{43}$ Ştefan et alii $1967,367$.

${ }^{44}$ Stefan et alii $1967,367$.

45 Vasiliu 1984, 107-125; Baumann et alii 1998, 34-35, nr. 41; Baumann et alii 2003, Sectorul „Cariera de lut” necropola (CT), 157; Baumann et alii 2004, Sector
}

în doi tumuli funerari romani ${ }^{46}$, datate în secolele XII-XIII), Troesmis-Turcoaia (secolele $\quad \mathrm{XII}-\mathrm{XIII})^{47}, \quad$ Enisala-Palancă (secolele XIII-XIV) $^{48}$, Ostrov, jud. Tulcea (secolele X-XII) ${ }^{49}$, precum şi la Capidava (secolele IX-XI) ${ }^{50}$, Constanța (secolele X-XI, probabil până la jumătatea secolului al XIlea $)^{51}$, Histria (secolele $\left.\mathrm{X}-\mathrm{XII}\right)^{52}$, Bugeac, com. Ostrov, jud. Constanța (secolele $\mathrm{X}-$ $\mathrm{XI})^{53}$, Păcuiul lui Soare (secolele XIIIXIV) ${ }^{54}$, Dervent (secolul al XI-lea) ${ }^{55}$, fiind foarte probabil ca cimitirul de la Dervent să aparțină, în întregime sau parțial, locuitorilor care au viețuit în secolul al XI-lea în interiorul zidurilor cetății de pe insula dunăreană Păcuiul lui Soare ${ }^{56}$, precum şi în cele din nord-estul Bulgariei actuale ${ }^{57}$. Au mai fost descoperite

Extramuros - Secțiunea 3, 148-149; Baumann et alii 2006, 185-186.

${ }^{46}$ Vasiliu 1984, 107, 125-129, 521-525, P1. II-III.

47 Vasiliu 1980a, 218-229 (morminte descoperite în zona cetății de est).

48 Lăzurcă, Mănucu-Adameşteanu 1980, 152-156; cercetări inedite 1984, 1986 Silvia Baraschi; Jugănaru et alii 2004, 119; Jugănaru et alii 2005, 144; Jugănaru et alii 2006, 153-154; Jugănaru et alii 2007, 146.

${ }^{49}$ Petre 1962, 584-586; Barnea et alii 2002, 226.

${ }^{50}$ Morminte în majoritate inedite - Florescu et alii 1961, 574, pl. I, 577-579, fig. 2-5; Florescu et alii 1962, 702703, fig. 1-3, 13-16; Irimia, Cliante 1986, 184, n. 21.

51 Irimia, Cliante 1986, 184, n. 22-23; MănucuAdameşteanu 1991b, 318 şi n. 61, 321 - cercetări inedite 1986 C-tin Chera şi Virgil Lungu.

${ }^{52}$ Condurachi et alii 1961, 233-234, fig. 6-8.

53 Chera-Mărgineanu 1981, 297-302.

54 Morminte descoperite în sectorul Poartă, încă inedite. Mențiuni: Diaconu 1963b, 557; Popa 1964, 109; Diaconu, Vîlceanu 1972, 55; Diaconu, Baraschi 1977, 10; Diaconu, Damian 1995, 67, nr. 93; Diaconu, Damian 1996, 87, nr. 103; Diaconu, Damian 1997, 4344, nr. 75; Diaconu et alii 1997, 67, nr. 47; Diaconu et alii 2003, 224; Diaconu et alii 2005, 252; Damian, Bănăseanu 2006, 249.

55 Diaconu 1963a, 213-216; Diaconu 1963b, 557 şi n. 33; Diaconu, Anghelescu 1968, 349; Baraschi 1977, 404 şi n. 17; Diaconu, Damian 1997, 43-44, nr. 75.

${ }^{36}$ Diaconu 1963a, 215; Diaconu 1963b, 557 şi n. 33.

${ }^{57}$ La Silistra (în zona zidului sudic al cetății, datate în secolele XII-XIV) - Angelova 1995, 99, pl. XVIII, cu analiză antropologică - Ciolakov 1995, 105-121) şi în jurul bisericii episcopale (datate începând cu secolul al X-lea până în epocă otomană - Angelova et alii 2005, 191; Angelova et alii 2002, 276, 280), Odărtzi, jud. Silistra - secolul al XI-lea (Donceva-Petkova 1993, 134 144; Donceva-Petkova 1998), Garvăn, jud. Silistra sfârşitul secolului al VIII-lea-începutul secolului al XIlea (Georgiev et alii 1969, 47; Văjarova 1986, 41-43, 
morminte izolate, databile în secolele X-XI la Niculiţel $^{58}$, Histria ${ }^{59}$ şi Gura Canliei ${ }^{60}$.

În ceea ce priveşte maniera de protejare a defunctului cu ajutorul unor lespezi aşezate pe cant de-a lungul scheletului ori prin clădirea unei cutii-sarcofag din pietre sau cărămizi de epocă romană şi romano-bizantină ${ }^{61}$, aceasta prezintă analogii atât în lumea anterioară, a necropolelor birituale, cât şi în a celor de inhumaţie, încadrabile cel mai târziu în secolul al XI-lea. Aceste morminte în casetă sau cistă de piatră apar pe tot teritoriul dobrogean, dar cu o concentrare mai mare în sudul provinciei. De bună tradiție romano-bizantină ${ }^{62}$, aceste „sarcofage" improvizate sunt atestate pentru secolele VIII-IX în cazul mormintelor din necropolele birituale de la Nalbant ${ }^{63}$, IstriaCapul Viilor ${ }^{64}$, Bdinci ${ }^{65}$ şi Topola $^{66}$. Cât priveşte mormintele de inhumație descoperite izolat sau făcând parte din necropole de acest tip, conținând acest gen de protecție, menționăm mormântul de la Adamclisi ${ }^{67}$ şi pe cel de la Niculițel $^{68}$. Mai trebuie menționate mormintele $\mathrm{cu}$ acest sistem de protecție descoperite pe teritoriul Constanței ${ }^{69}$, cele 9 morminte săpate în umplutura de cretă a carierei de la Murfatlar-

61-63, 191, 193-195, 197, 210, fig. 39), Cavarna secolele VIII-XI (Mircev 1961, 67-76) şi Caliacra secolele XIII-XIV (Michailov 1971, Bobceva 1978, 152). 58 Ştefan et alii 1955, 737, 739-740, fig. 26; MănucuAdameşteanu 1991c, 361-364.

${ }^{59}$ Suceveanu 1973, 495-502.

${ }^{60}$ Irimia 1981, 117; Irimia 1982, 140-143.

${ }^{61}$ Baraschi 1977, 407.

${ }^{62}$ Fiedler 1992, 277; Diaconu 1993, 293

${ }^{63}$ M 12 ce pare să fi fost protejat cu pietre sub forma a două plăci de gresie - Simion 1971, 231-232, pl. IV/4; Irimia, Cliante 1986, 182; Mănucu-Adameşteanu 1991c, 361 și n. 5.

${ }^{64} \mathrm{O}$ parte dintre mormintele de înhumație, orientate E-V erau în casete de piatră - Zirra 1963, 365, fig. 8/5 M 25, 6 - M 252, 8 - M 132; Fiedler 1992, taf. 11/6 - M 25; taf. 17/10 - M 101; taf. 21/2 - M 132; taf. 23/6 - M 152; taf. 26/5 - M 214; taf. 33/6-7 - M 252. Unul dintre mormintele cu casetă de piatră - M 252 - avea drept inventar un vas depus la picioare, databil în secolul al IXlea (Zirra 1963, 355-412, fig. 8/6; Irimia, Cliante 1986, 182; Mănucu-Adameşteanu 1991c, 362 şi n. 12).

${ }^{65}$ Văjarova 1976, 5-30; Văjarova 1981, 77-109.

${ }^{66}$ Donceva-Petkova et alii 1989, 190-193, fig.7-8.

${ }^{67}$ Panaitescu 1983, 157-158.

${ }^{68}$ Mănucu-Adameşteanu 1991c, 361.

69 Irimia, Cliante 1986, 184 şi n. 22-23; MănucuAdameşteanu 1991b, 321.
Basarabi $^{70}$, mormântul în cistă de piatră descoperit în necropola de la Sitorman-Mihail Kogălniceanu ${ }^{71}$, cele 2 morminte de inhumație protejate cu blocuri de piatră de la Ostrov $^{72}$, precum şi cele 5 morminte descoperite pe dealul Dervent $^{73}$. Acestora li se adaugă mormintele de inhumație în ciste de piatră din necropolele creştine de la Cavarna ${ }^{74}$, Chitovo ${ }^{75}$, Durankulak $^{76}$, Krăgulevo ${ }^{77}$, Bălgarevo ${ }^{78}$, Devnja $^{79}$, legate de momentul creştinării bulgarilor în timpul țarului Boris-Mihail (865).

În privința categoriilor de obiecte de podoabă prezente în inventarele mormintelor amintite, trebuie precizat că acestea au fost deja semnalate la Nufăru în necropola documentată în punctele Piatră $\breve{c}^{80}$ şi Trecere $b a c^{81}$.

Cercei cu veriga simplă, cu secțiunea circulară, lucrați dintr-o sârmă cu grosime variabilă de cupru, bronz sau argint, cu capetele apropiate, consideraţi uneori inele de tâmplă/buclă, având diverse diametre, sunt

70 Morminte înconjurate de un rând de lespezi dreptunghiulare, cioplite din blocuri de cretă, deasupra cărora erau aşezate pe lat, de-a curmezişul, alte lespezi de acelaşi tip (Barnea, Ştefănescu 1971, 222-223, 228; Barnea 1987, 104).

71 Cistă confecționată dintr-un singur bloc de calcar cochilifer, lung de 1,15/1,30 m, de formă aproximativ trapezoidală, cu orientare vest-est, adăpostind un schelet de copil (Irimia, Cliante 1986, 179-181, fig.1; 2-3, 185, 188).

72 Chera-Mărgineanu 1981, 297-301; MănucuAdameşteanu 1991c, 362 şi n.9.

${ }^{73}$ Diaconu, Damian 1997, 44; descoperiri inedite (informație Oana Damian).

${ }^{74}$ Mircev 1961, 69, fig.5; 70, fig.7; 71, fig.9; 73, fig.12; 74, fig.14.

${ }_{75}^{75}$ Botov 1977, 177-183, pl. II, IV.

${ }^{76}$ Melamed 1987, 83-92; Melamed 1989, 113-133, 142-147, fig.2, 6, pl. I.

${ }^{77}$ Bobceva 1984, 53-58, pl. I-II.

${ }^{78}$ Bobceva, Salkin 1973, 176, pl. $\mathrm{I}_{2}$.

${ }^{79}$ Fiedler 1992, taf. 104/16-17 - M 123.

${ }^{80}$ Cercei tip verigă - doi cercei din argint (Baraschi, Moghior 1980, fig. 6/1-2; Damian 1993, 19, n. 88, 109), mărgele de sticlă (Damian 1993, 92-95, 109-112, fig. 8-9;), mărgele de chihlimbar (Damian 1993, 94-96, 111-112, fig. 9), brățări de sticlă (Damian 1993, 96-98, $110-111$, fig. 10).

${ }^{81}$ Mărgele - Damian et alii 2000, 68; Damian et alii 2003b, 214; Damian et alii 2005, 246; Damian et alii 2007b, 242; brățări de sticlă - Damian et alii 2001, 164; Damian et alii 2003b, 214; Damian et alii 2006, 238; Damian et alii 2007b, 242. 
documentați în mormintele dobrogene de la Bisericuța-Garvăn ${ }^{82}, \quad$ Histria $^{83}, \quad$ Dervent $^{84}$, Păcuiul lui Soare ${ }^{85}$ şi în Bulgaria de nord-est ${ }^{86}$. În aşezările corespondente necropolelor amintite sunt atestați la Bisericuța-Garvăn ${ }^{87}$, Păcuiul lui Soare ${ }^{88}$ şi în nord-estul Bulgariei ${ }^{89}$. Prezența mărgelelor de sticlă $\breve{a}^{90}$ în morminte, având diverse forme, culori şi particularități stilistice, este documentată în Dobrogea în morminte descoperite la NoviodunumIsaccea $^{91}$, Dervent ${ }^{92}$ şi Histria ${ }^{93}$, precum şi în

${ }^{82}$ Doi cercei de acest tip, dintre care unul din aur, descoperiți în două morminte distincte (Ştefan et alii 1967, 287, 273).

83 Două inele de tâmplă din bronz într-un mormânt izolat (Suceveanu 1973, 498, fig. 3/4-5).

84 Într-un mormânt de pe dealul Dervent a fost descoperit un cercel cu veriga simplă de argint (Diaconu, Damian 1997, 44).

${ }^{85}$ Diaconu et alii 2005, 252.

${ }^{86}$ La Garvăn, jud. Silistra (4 cercei sub forma unor verigi simple de cupru şi bronz - Văjarova 1986, 6163, 191, 193, 197, fig. 58/1-4, 211/5, 7), Odărtzi, jud. Silistra (un număr neprecizat de cercei din cupru, bronz şi argint - Donceva-Petkova 1993, 137, 139, Tab. III/2; Donceva-Petkova 1998, 126-127, fig. 1. b-d), Silistra (12 cercei din cupru - Angelova 1995, 65, 68-73, 8384, 87-88, 94, 100-101, Tab. II-III, VI-VII, XIII, XIX-XX; Angelova et alii 2005, 192) şi la Caliacra Bobceva 1978, 161, dintre care 6 de argint (Bobceva 1978, 166, 170, 177-179, Tab. V/53, IX/142, 144, XV/302, XVII/351), 54 de cupru (Bobceva 1978, 167179, Tab. VI/82, VII/100, 116, VIII/120, 123, 131, 133, $\mathrm{IX} / 135,140,145,147, \mathrm{X} / 160,165,174,185, \mathrm{XI} / 188$, 191, 193, 201, 218, XII/220, 232, 238, XIII/246, 247, $249,250,256,265,271, \mathrm{XIV} / 284,286,304,305,317$, $320, \mathrm{XVI} / 328,334,336,342,344,346)$.

${ }^{87}$ Ştefan et alii 1967, 285, 287-288, fig. 170.

88 Descoperiți în număr mare, ei sunt atât din bronz, cât şi din argint (Diaconu, Baraschi 1977, 122-123, fig. 97/1-12).

${ }^{89}$ La Garvăn, jud. Silistra (Văjarova 1986, 148-149, 190, 192, fig. 153/7, 209/2), Odărtzi (Donceva-Petkova 1999, 100, fig. 131/577-579, Tab. XLVI/577-579).

${ }^{90}$ Despre problema mărgelelor de sticlă, a se vedea Stefan et alii 1967, 315-325; Diaconu, Vîlceanu 1972 , 317-139; Văjarova 1975.

91 Vasiliu 1980b, 482-485, fig. 2/6-7; Vasiliu 1984, 113-114, 121-126, 128, 131-133, 532, 534-536, 539, pl. VIII, X-XII, XVI.

92 Într-unul dintre mormintele necropolei (încă inedită) a fost descoperit un colier din mărgele de sticlă circulare, aplatizate, albe, puterinc irizate (Diaconu, Damian 1997, 44)

${ }_{93}$ Într-un mormânt izolat din sectorul Terme II (ER) au fost documentate unsprezece mărgele de sticlă sferice şi bitronconice, de culori diferite (Suceveanu 1973, 498, fig. 3/6-16). partea răsăriteană a Bulgariei septentrionale ${ }^{94}$. Deşi se găsesc în mai mică măsură în aşezări, fiind descoperiri specifice mai degrabă necropolelor ${ }^{95}$, aceste piese sunt atestate şi în cadrul aşezărilor de la Noviodunum-Isaccea ${ }^{96}$ şi din nord-estul Bulgariei ${ }^{97}$. Mărgele de chihlimbar, destul de rare în Dobrogea, apar, în afara descoperirilor deja cunoscute de la Nufăru, şi în mormintele din necropolele de la Isaccea (necropola plană) ${ }^{98}$ şi Silistra ${ }^{99}$ pentru Bulgaria de nord-est. Brățările de sticlă ${ }^{100}$, înscriindu-se tipologic în mai multe categorii, în general de culoare albastră, dar variabile şi din acest punct de vedere, sunt atestate în cimitirele dobrogene de la Dinogetia-Garvăn ${ }^{101}$,

${ }^{94}$ La Cavarna (la mormântul nr. 2 din tumulul A Mircev 1961, 69, fig. 4), Odărtzi, jud. Silistra (DoncevaPetkova 1993, 138-139, Tab. III. 1-2; Donceva-Petkova 1998, 126-129, fig. 2. a-f), Garvăn, jud. Silistra (Văjarova 1986, 62-63, fig. 58/9-10), Silistra (Angelova 1995, fig. 10, Tab. II, 66-69, 81; Angelova et alii 2005, 192) şi Caliacra (Bobceva 1978, 174, 178, Tab. XII/234, XV/323).

${ }^{95}$ Diaconu, Vîlceanu 1972, 137.

${ }^{96}$ Barnea, Barnea 1984, 103.

${ }^{97}$ La Garvăn, jud. Silistra (Văjarova 1986, 105, 107, 190, 192, obr. 95/2, 209/3), Odărtzi (Donceva-Petkova 1999, 101, Tabl. XLVI/587-605).

${ }^{98}$ Vasiliu 1980b, 483-484, fig. 2/5; Vasiliu 1984, 114, 123-125, 131, 133, pl. VIII/1, 3-4.

${ }^{99}$ Două mărgele (Angelova 1995, 67-68).

${ }^{100}$ Brățările de sticlă cunosc o largă răspândire în timp şi spațiu, la Dunărea de Jos fiind frecevent întâlnite încă din secolele IV-VI. Ca inventar funerar în această perioadă sunt documentate în necropola de la Mangalia (Diaconu 1964, 719, fig. 1/4; Preda 1980, 52-53, pl. XXII, XLVI, LXIII, LXIV, XXIII, LXXII), iar în afara Dobrogei, în cea de la Bratei (Bârzu 1973, 69-70, cu reflecții asupra semnificației creștine a brățărilor în acea perioadă). Absente total în Dobrogea secolelor VII-X, brățările de sticlă reapar abundent în aşezările şi necropolele din acest areal după reconquista bizantină. Este semnificativ în evoluția sincopată a acestor piese faptul că fabricarea lor este reluată în Dobrogea din secolul al XVII-lea; în satul Nufăru, ce suprapune cetatea medievală şi necropolele ce fac obiectul de studiu al acestui articol, folosirea brățărilor de sticlă a cunoscut o longevitate deosebită, fiind atestată conform relatărilor orale şi descoperirilor arheologice până în secolul al XX-lea (Mănucu-Adameşteanu 1984b, 242243).

101 În necropola din jurul bisericutei au fost documentate la un număr neprecizat de schelete cu brățări de sticlă dispuse câte două pe acelaşi braț, inclusiv la morminte de copii (Ştefan et alii 1967, 314; Barnea, Ştefănescu 1971, 314, n. 270); în zona cimiterială din sectorul thermelor romane din secolul al IV-lea suprapuse de o aşezare din secolele X-XI şi la vest de acestea, într-unul din cele 20 de morminte au fost descoperite 4 brățări de sticlă dispuse câte 2 pe fiecare 
Noviodunum-Isaccea ${ }^{102}$, Troesmis-Turcoaia ${ }^{103}$, Ostrov-Beroe ${ }^{104}$, Dervent ${ }^{105}$ şi în Bulgaria de nord-est $^{106}$. Ele sunt descoperite frecvent şi în aşezările corespondente acestor necropole, de obicei în stare fragmentară. Sunt menționate ca descoperiri în aşezările de la DinogetiaGarvăn $^{107}$, Noviodunum-Isaccea ${ }^{108}$, TroesmisTurcoaia $^{109}$, Ostrov-Beroe ${ }^{110}$, precum şi în Bulgaria de nord-est ${ }^{111}$.

În ceea ce priveşte depunerea monedelor în morminte, menționăm prezența acestora în mormintele din necropola de la Nufăru, punctul Piatră $^{112}$, precum şi în necropolele de la Noviodunum-Isaccea ${ }^{113}$, Ostrov (jud.

braț al defunctului (copil) (Branea 1973, 298, 301, 304, fig. 8/2-3); 3 brățări de sticlă au fost descoperite într-unul dintre cele 3 morminte din sectorul „Domus” (Barnea 1973, 330); mai sunt menționate 7 morminte cu brățări albastre pe malul gârlei Lăţimea (Mănucu-Adameşteanu 1991c, 363, n. 14).

102 Vasiliu 1980b, 482-483, fig. 2/1-4; Vasiliu 1984, 110-111, 117-119, 121-131, 530-531, 533-539, 526, pl. VI-VII, IX-XVI; Baumann et alii 2006, Sector Turn A (Ta), 183, Sector Turn Colț (TC), 184, Sector Cariera de lut - Necropola, 186.

${ }^{103}$ În doar 2 morminte (Vasiliu 1980a, 220, pl. 24/fig. 3-6).

${ }^{104}$ Ştefan et alii 1967, 314 şi n. 144.

1058 brățări de sticlă depuse pe umărul drept (Diaconu 1963a, 213-214, fig. 3; Diaconu 1963b, 557, n. 33; Diaconu, Vîlceanu 1972, fig. 61).

${ }^{106}$ La Odărtzi, jud. Silistra (Donceva-Petkova 1993, 138; Donceva-Petkova 1998, 129, 130, fig. 3. a-e) și Silistra (Angelova 1995, 66, 70-71, 88-89, 100, Tab. XIX; Angelova et alii 2005, 192); un fragment dintr-o brățară de sticlă a fost descoperită şi într-unul din mormintele de la Garvăn (jud. Silistra) (Văjarova 1986, 62-63, fig. 58/8).

107 Ştefan et alii 1967, 302-315, fig. 174-176; Barnea 1961, 53, 81, fig. 34/4-5; Vasiliu 1991, 377, 380-381.

108 Santierul..., 180, fig. 16/2; Mănucu-Adameşteanu 1984b, 241-242, pl. II; Barnea, Barnea 1984, 103.

109 În urma unor cercetări perieghetice (Ştefan et alii 1967, 314, n. 140).

${ }^{110}$ Cercetări de suprafață (Ştefan et alii 1967, 314 şi n. 141).

${ }^{111}$ La Garvăn, jud. Silistra (Văjarova 1986, 87-88, fig. 71/4, 105, 107, 159-160, fig. 95/3, 168/6), Odărtzi (Donceva-Petkova 1999, 101, fig. 132/606, Tabl. XLVI/609 a-d).

112 Damian 1993, 105, 109.

113 În necropola plană au fost documentate în context funerar patru monede de bronz, două de la Roman al III-lea Argyros (în M 58 şi M 68) şi două de la Mihail al IV-lea Paphlagonianul (ambele în acelaşi mormânt, al copilului din M 45), descoperite exclusiv în palmele
Tulcea) ${ }^{114}$ şi în cele din nord-estul Bulgariei ${ }^{115}$. Penuria atestărilor nu permite emiterea unor aprecieri globale cu privire la răspândirea şi semnificația acestui obicei moştenit din epoca romană în contextul necropolelor creştine bizantine. Problematica suscitată de acest tip de descoperiri merită însă adusă în discuție, fără pretenția exhaustivității sau a rezolvării ei imediate. Sunt de menţionat implicațiile atribuirii cronologice a mormintelor posedând un asemenea tip inventar, fiind de reamintit situația menționată mai sus a mormântului 19/proprietatea Ducica, 2005. Nu este vorba despre un caz singular, prezența unor situații similare constatându-se şi în necropola de la

mâinilor drepte ale defuncților (Vasiliu 1984, 116, 122 123, pl. XVI/9a-b, 10a-b, 11a-b, 12a-b).

114 Din totalitatea mormintelor medievale, nepublicate integral, este menționat deocamdată un singur caz de depunere a unei monede (Barnea et alii 2002, 226). Din totalitatea mormintelor medievale, nepublicate integral, este menționat deocamdată un singur caz de depunere a unei monede (Barnea et alii 2002, 226). Vezi şi Stănică 2004, 361.

${ }^{115}$ Odărtzi (7 monede de argint perforate (cu câte două găuri fiecare), dintre care 6 emisiuni ale împăraților Leon VI (896-912) - un exemplar, Vasile II (cca. 989) - 3 exemplare, Vasile II şi Constantin VIII (9891025) - un exemplar şi Constantin IX Monomachul (1042-1055) - un exemplar - Donceva-Petkova 1998, 134; de precizat că 3 monede provin din acelaşi mormânt - M 109 - emisiunea Leon VI şi 2 monede Vasile II - Donceva-Petkova 1993, 140, 144; cel mai frecvent, monedele au fost descoperite în jurul gâtului defunctului - Donceva-Petkova 1998, 134). Silistra (lângă cotul mâinii stângi a scheletului din mormântul nr. 8 a fost găsită o monedă bizantină anonimă clasa $D$ (1050-1060), iar lângă genunchiul piciorului stâng al aceluiaşi schelet a fost descoperită o monedă de la împăratul Honorius (393-423); în mormântul nr. 17, în partea stângă a femurului/coxalului stâng, sub acesta, se afla o monedă de la Constantin X şi Evdokia (10591067); scheletul mormântului nr. 18 avea o monedă bizantină anonimă clasa D (1050-1060) lângă femurul/coxalul drept; câte o monedă bizantină anonimă clasa A2 (976-1030/35) se afla şi în partea stângă a scheletelor din M 21 şi M 24; o monedă bizantină anonimă clasa G (1065-1070) se afla printre oasele femurale/şoldului scheletului din $\mathrm{M} 42$; o monedă de la Arcadius (383-408) în zona genunchilor scheletului din M 57, o monedă emisiune a lui Theodor Laskaris (1208-1222) lângă podoabele defunctului din M 71; printre oasele femurului/şoldului scheletului din M 74 se afla o monedă imitaţie bulgărească tip C, deceniile V-VI ale sec. XIII; tot la acest schelet se afla o monedă de la Ioan Alexandru (1331-1371) Angelova 1995, 68-71, 73). 
Silistra, unde lângă genunchiul piciorului stâng al scheletului din M 8 a fost descoperită o monedă de la împăratul Honorius (393-423), iar în zona genunchilor scheletului din M 57, o monedă de la Arcadius (383-408) ${ }^{116}$. Tot aici, alături de o monedă din a doua jumătate a secolului al XIV-lea, se afla şi una din a doua jumătate a secolului al XIII-lea ${ }^{117}$. Nu este vorba despre o practică specific medievală, fenomenul fiind întâlnit şi în epoca romanobizantină $^{118}$. În privința locului unde se depuneau monedele-obol, faptul că nu toate au fost descoperite în gura sau palmele defuncților nu constituie un impediment pentru a presupune implicațiile ritualice ale depunerilor numismatice în morminte ${ }^{119}$. În ceea ce priveşte mormintele de la Nufăru aflate în această situație, putem totuşi presupune că, în cel puțin două cazuri (M 19 - proprietatea Ducica) şi M 57 - proprietatea Drăgan) monedele se aflau în mâinile defuncților, fiind descoperite în apropierea locului pe care erau poziţionate palmele.

În ceea ce priveşte epoca modernă, există mai multe nuclee de înmormântare. Unul dintre ele, probabil cel mai important, poate fi delimitat în zona Căminului cultural. A fost identificat în 1980 chiar în curtea căminului cultural ${ }^{120}$, definit prin 6 morminte (catalog, pozițiile 74-79; fig. 19), conținând schelete în decubit dorsal, cu orientarea V-E, 5 de adulți (catalog, pozițiile 74-77) şi unul

\footnotetext{
116 Angelova 1995, 68, 71 .

117 Angelova 1995, 73; trebuie precizat, în aceeaşi ordine de idei, că, deşi necropola de la Silistra este încadrată cronologic în secolele XII-XIV, cu un hiatus de jumătate de secol datorat invaziei mongole, monedele provenind din morminte sunt majoritar de secol XI (vezi catalog în Angelova 1995, 68-71).

118 In necropola de la Callatis, într-un mormânt, alături de o monedă din perioda lui Valens, se afla şi una din bronz perforată din prima jumătate a secolului al II-lea (Preda 1980, 64).

119 Amintim că şi în cazul necropolei de la Callatis monedele au fost descoperite nu doar în gura defuncților, ci şi în palmă, sub antebraț, lângă tibii, lângă femur, lângă laba piciorului sau lângă peretele de sud al mormântului (Preda 1980, 65).

${ }^{120}$ Mănucu-Adameşteanu, Mănucu-Adameşteanu 1986,

211, n. 8. Precizăm că oseminte umane au mai fost observate, tot în curtea căminului cultural, în 2003, distruse cu ocazia amenajării unui grup sanitar.
}

de copil (catalog, poziția 78) cu antebrațele dispuse în poziții diferite - ambele pe abdomen (catalog, pozițiile 74,78 ) sau pe bazin (catalog, poziția 79), dreptul pe abdomen, stângul pe bazin (catalog, poziția 76) doar stângul pe abdomen (catalog, poziţia 75), conținând drept piese de inventar: monede (emisiuni Mahmud II, 1809/1810, 1824/1825), mărgele, nasturi, ace de păr ${ }^{121}$ (catalog, pozițiile 74-75, 78; fig. 29).

Informația poate fi completată cu aceea oferită de mormintele cercetate la est de clădirea şi curtea Căminului cultural, în casetele practicate în şanțul pentru alimentarea cu apă a localităţii trasat în 2006 pe str. Bisericiii $^{122}$ (catalog, pozițiile 80-91; fig. 2022/1), conturându-se o necropolă ce se extinde atât la nord, cât şi la sud de Căminul cultural, pe o distanţă de circa $200 \mathrm{~m}$. La nord de Căminul cultural, au fost identificate mai multe morminte cu ocazia realizării alimentării cu apă pe str. Bisericii - în zona zidului de incintă sudic, în dreptul proprietăților de la nr. 169 şi 93 - 4 morminte descoperite în zona zidului de incintă de sud, unul în 1981 (catalog, poziția 97), ce suprapune parțial un mormânt de copil cu brățări albastre ${ }^{123}$ şi 3 în 2006 (ce suprapun nivelul funerar bizantin, în S 2 Fortificație Cămin, caseta A - catalog, pozițiile 104-106), precum şi în zona intersecției străzii Bisericii cu DJ $222 \mathrm{C}^{124}$ 3 morminte (catalog, pozițiile 110-112). La sud de căminul cultural, descoperirile au fost prilejuite fie de intervenţii umane întâmplătoare (proprietatea Dobrin, str. Bisericii 94, 2001-2002 - catalog, pozițiile 70-73), fie de intervenții de salvare (morminte

\footnotetext{
${ }^{121}$ Mănucu-Adameşteanu, Mănucu-Adameşteanu 1986, 211, n. 8.

${ }^{122}$ La est de Căminul cultural, într-o porțiune a șanțului pentru alimentare cu apă, lungă de 7,60 m (ax N-S), au fost cercetate 7 morminte şi recuperate 3 grupuri de oseminte, componente ale mai multor complexe funerare distruse în momentul săpării mecanice a şanțului.

${ }_{123}$ Mănucu-Adameşteanu, Mănucu-Adameşteanu 1986, 211-212.

${ }^{124}$ Grupaj de 3 morminte pe axa S-N, pe o lungime de $9,50 \mathrm{~m}$.
} 
deranjate de apa pluvială, înregistrate în $1999^{125}$ (catalog, poziția 66), fie de cercetări preventive, desfassurate pe proprietăţi particulare afectate de proiecte constructive (str. Bisericii nr. 98, proprietatea A. Husein, în $2005^{126}$ şi 2007 - catalog, poziţiile 42-43; fig. 18) ori prilejuite de alimentarea cu apă a localităţii (str. Bisericii, zona cuprinsă între proprietățile cu nr. 94 şi 105, în 2006 catalog, pozițiile $30,33,36,45-46,58-61$, 63-64, 68).

Acelaşi proiect de alimentare cu apă a localităţii Nufăru a prilejuit descoperiri funerare şi într-o zonă apropiată str. Bisericii, şi anume pe str. Rapsodiei, paralelă şi situată la est de aceasta -12 complexe $^{127}$ (catalog, poziţiile 113-126) şi pe str. C-tin. Dobrogeanu Gherea, perpendiculară pe străzile Bisericii şi Rapsodiei - 4 complexe. (catalog, pozițiile 24-27; fig. 18). Probabil toate aceste complexe funerare (62) aparțin aceleiaşi necropole situate topografic la sud de zidul de incintă bizantin.

Mormintele atribuibile acestui orizont funerar cercetate în 2006, multe deranjate de amenajările stradale moderne, se remarcă, asemeni celor din 1980, prin aceeaşi orientare V-E, utilizarea sicrielor, documentate prin prezența amprentelor sau a fragmentelor mai consistente de lemn, varietatea poziției antebrațelor, sesizată în cazul scheletelor în conexiune anatomică — s-au înregistrat mai multe variante (încrucişate pe piept, abdomen, bazin sau umeri ori întinse pe lângă corp), cu subvariantele lor, fiind înregistrate 5 complexe funerare în care a putut fi precizată poziția ambelor antebrațe (pe piept - catalog morminte, poziția 80 sau pe bazin - poziţia 33, antebrațul stâng pe lângă corp - pozițiile 42 şi 66, cu antebrațul drept poziționat fie sub claviculă — poziția 42 , fie pe bazin — poziția

\footnotetext{
125 Damian et alii 2000, 67.

${ }^{126}$ A fost menționată greşit ca fiind proprietatea Iacob Vasiliev, în Mănucu-Adameşteanu et alii 2007, 377.

127 Un mormânt izolat, distrus de apele pluviale, a fost identificat în 2002 pe str. Rapsodiei, aproape de intersecția cu str. Ctin. Dobrogeanu Gherea, în dreptul proprietății Enache-Odică.
}

66, antebrațul drept pe umăr şi oasele antebrațului stâng depuse lângă tibia dreaptă poziția 85) şi 2 situații în care s-a putut observa doar poziția unuia dintre antebrațe (catalog morminte, pozițiile 68 - antebrațul drept pe abdomen - şi 86 - antebrațul stâng pe abdomen). În ceea ce priveşte inventarul funerar, prezent doar în 3 situaţii (catalog, pozițiile $25-26,68)$, este reprezentat de obiecte de port (o pafta de bronz - catalog morminte, poziția 26) ori de monede reprezentând obolul lui Charon - monede de argint otomane emisiuni Ahmed III (1703-1730) şi Imperiul otoman, secolul al XVIII-lea ${ }^{128}$ (catalog morminte, pozițiile: 25,68 ). Observăm că, raportat la cele circa 100 de complexe funerare aparținând epocii moderne, inventarul funerar este prezent doar în 7 situații (catalog, pozițiile $25-26,68,70,74-75,78$ ), fiind reprezentat de modeste obiecte personale, de podoabă sau de port (catalog morminte, pozițiile 26, 75-78; fig. 29/5) ori de monede reprezentând obolul lui Charon - monede otomane - emisiuni Ahmed III (1703-1730), Murad II (1809/1810 şi 1824/25) şi Imperiul otoman, secolul al XVIII-lea (catalog morminte, pozițiile: 25, 68, 70, 74-75, 78). Credem că aceste piese, prezente în inventarele mormintelor cercetate în 1980, respectiv 2001 şi 2006, în curtea şi în zona înconjurătoare a Căminului cultural, definesc perioada de funcționare a acestei necropole.

Morminte încadrabile epocii moderne au mai fost identificate pe străzile Zimbrului (perpendiculară pe latura estică a str. Turnului, la sud de intersecția cu str. C-tin. Dobrogeanu Gherea $^{129}$ - catalog, pozițiile 127-131), Aurel Vlaicu (perpendiculară pe str. Turnului, la sud de punctul Râpă - catalog, pozițiile 132-134; fig. 23; 27/4), Miron Costin (catalog, pozițiile

\footnotetext{
128 Identificare Aurel Vâlcu (Institutul de Arheologie „Vasile Pârvan”), pentru care îi mulțumim.

${ }^{129} \mathrm{Pe}$ str. Zimbrului au fost recuperate oase umane provenind din morminte cu schelete orientate $\mathrm{V}-\mathrm{E}$, adică paralele cu axul străzii şi al şanțului săpat pe latura sudică, distruse de excavator, ce nu au putut fi documentate prin ilustrare.
} 
135-157; fig. 23-27) şi Trandafirilor (catalog, pozițiile 158-162), conturând probabil un alt nucleu cimiterial ${ }^{130}$, diferit de cel aflat în perimetrul delimitat de străzile Bisericii, Rapsodiei şi C-tin. Dobrogeanu-Gherea (reprezentat deocamdată de 36 de complexe funerare). $\mathrm{O}$ atenție specială merită segmentul de necropolă ce a putut fi identificat pe str. Miron Costin ${ }^{131}$. Prin raportare la cele 15 complexe funerare in situ, săpate parțial, se constată depunerea în gropi individuale, în decubit dorsal, orientarea scheletelor V-E, varietatea poziției antebrațelor, sesizată în cazul scheletelor în conexiune anatomică, fiind înregistrate 2 complexe funerare pentru care a putut fi precizată poziția ambelor antebrațe (catalog morminte, pozițiile 137 - antebraţul drept pe piept, stângul pe abdomen şi 140 antebrațul drept pe lângă corp, stângul pe abdomen) şi 3 situații în care s-a putut observa doar poziția unuia dintre antebrațe (catalog, pozițiile 136, 147 - antebrațul stâng pe bazin, 139 - dreptul pe lângă corp, atingând bazinul).

Astfel, necropolei de pe str. Bisericii, din zona Căminului cultural, încadrabilă în secolele XVIII-XIX, îmbogăţită prin noi descoperiri, pe străzile Rapsodiei şi Dobrogeanu-Gherea, i se adaugă încă una, probabil apropiată din punct de vedere cronologic, eventual mai târzie, în zona circumscrisă de străzile Trandafirilor, Miron Costin, Zimbrului şi Aurel Vlaicu. Din păcate, în absența oricărui element de inventar sau indiciu stratigrafic, ne aflăm doar în sfera supoziţiilor.

Necropolele moderne identificate pe teritoriul satului Nufăru îşi găsesc analogii în Dobrogea în descoperirile din diverse puncte

\footnotetext{
${ }^{130}$ Acestei necropole i se poate încadra, eventual, şi o descoperire întâmplătoare din anii 80 ai secolului al XX-lea, făcută în apropierea actualei străzi E. Racoviță, reprezentată de un mormânt de inhumație aflat la adâncimea de $1 \mathrm{~m}$ de la nivelul actual de călcare, în sicriu de lemn, cu scheletul orientat V-E, cu antebrațele pe bazin (informație Gh. Mănucu-Adameşteanu).

${ }_{31}$ Pe str. Miron Costin au putut fi identificate 15 complexe funerare şi recuperate opt grupuri de oase umane, provenind de la morminte deranjate în timpul excavării şanțului pentru alimentarea cu apă în 2006, înainte de cercetarea propriu-zisă.
}

de pe teritoriul oraşului Tulcea ${ }^{132}$, în cele de la Enisala - punctele La Bucluc şi La Biserică $^{133}$ Isaccea - cimitirul din jurul bisericii Sf. Gheorghe ${ }^{134}$, Niculițel — biserica Sf. Athanasie ${ }^{135}$, Luncavița - punctul Cetățuia $^{136}$, Sabangia ${ }^{137}$, Sarichioi ${ }^{138}$, toate în jud. Tulcea, Ester - Târguşor, jud. Constanța, datate în secolele XVIII-XIX ${ }^{139}$.

Ace de păr se cunosc în Dobrogea în necropola de la Luncavița ${ }^{140}$, iar mărgele din pastă de sticlă apar în morminte identificate în necropola de la Ester - Târguşor ${ }^{141}$. Paftale asemănătoare celei descoperite la Nufăru, databile în secolele XV-XVIII, sunt cunoscute în Dobrogea ca descoperiri de tip inventar funerar într-un mormânt de la Isaccea $^{142}$, într-unul descoperit la Niculițel ${ }^{143}$, precum şi în complexe din necropola de la Ester - Târguşor ${ }^{144}$. Acest tip de piesă, considerată deopotrivă accesoriu vestimentar

\footnotetext{
132 Paraschiv, Nuțu 2007, 383; cercetări inedite Aurel Stănică, 2007.

${ }^{133}$ Mănucu-Adameşteanu 1984c, 355-362; Stănică et alii 2005-2006, 319-321 şi n. 23.

${ }^{134}$ Vasiliu 1995, 374-377. Pe baza analogiilor sugerate de situațiile şi materialul arheologic înregistrate, cât şi a unor cruci din piatră aflate în curtea bisericii, cimitirul poate fi datat la sfârşitul secolului al XVIII-lea şi în prima jumătate a secolului al XIX-lea (informație Aurel Stănică).

${ }^{135}$ Bătrâna, Bătrâna 1977，540 - 70 de morminte databile în secolele XVIII-XIX, descoperite în curtea bisericii Sf. Athanasie.

${ }^{136}$ Comşa 1962, 222 şi n. 3 - 5 morminte, 2 de adulți şi 3 de copii, datate cu monede emise în vremea sultanilor Mahmud I (1730-1754) şi Abdul Hamid I (1774-1789); Micu et alii 2005, 209-210 — 2 morminte, dintre care unul cu inventar constând din copci de bronz, un ac de păr şi monede din vremea domniei lui Abdul Hamid I — anul 13 - 1786/1787.

137 Materiale inedite aflate în colecția ICEM Tulcea (informație Aurel Stănică).

${ }^{138}$ Materialele publicate de I. Vasiliu (Vasiliu 1996, 225-242, catalog nr. 1 - PlI/1; II/6a-b; nr. 2 - Pl. I/56; II/4-5; nr. 3 - Pl. I/2; II/2; nr. 4/Pl. I/4; II/1; nr. 7 Pl. II/7; nr. 8 - Pl. I/3;II/3) sunt recuperate dintr-o zonă în care au fost distruse mai multe morminte datate în secolele XVII-XVIII (vezi Lungu, MănucuAdameşteanu 1995, p. 349, n. 5).

${ }^{139}$ Custurea 1986, 300-301, fig. 1.

${ }^{140}$ Micu et alii, 210.

${ }^{141}$ Custurea 1986, 300.

${ }^{142}$ Vasiliu 1995, 375, 390, 408, pl. V/5.

${ }^{143}$ Bătrâna, Bătrâna 1977, 540.

${ }^{144}$ Custurea 1986, 302, fig. 2.
} 
şi garnitură de curea, provine din relativ multe descoperiri întâmplătoare din nordul Dobrogei ${ }^{145}$, unele putând reprezenta, eventual, chiar descoperiri funerare, neprecizate însă întotdeauna. ${ }^{146}$

Ace de păr se cunosc în Dobrogea în necropola de la Luncavița ${ }^{147}$, iar mărgele din pastă de sticlă apar în morminte identificate în acelaşi sit ${ }^{148}$, precum şi în cea de la Ester Târguşor ${ }^{149}$

Practica depunerii de monede în această epocă este destul de frecventă. Astfel, pe teritoriul satului Enisala, în punctele La Bucluc şi La Biserică, au fost identificate morminte databile cu un grosetto emis de Ragusa, ce a circulat, în secolul al XVII-lea şi în prima jumătate a secolului al XVIII-lea, cu parale otomane atribuibile perioadei domniei sultanului Ahmed III (1703-1730) şi secolului al XVIII-lea ori cu aspri emişi în secolul al XVII-lea ${ }^{150}$. În inventarele unora dintre mormintele aparținând cimitirului din jurul bisericii Sf. Gheorghe de la Isaccea au fost descoperite emisiuni ale sultanilor Selim III (1797) şi Murad II (1812) $)^{151}$. Mormintele de la Luncavița conțin emisiuni ale sultanilor Mahmud I (1730-1754) şi Abdul Hamid I $(1774-1789)^{152}$; de asemenea, în mormintele necropolei de la Ester-Târguşor a fost documentată prezența monedelor în 11 dintre cele 13 morminte identificate, fiind reprezentate de aspri emişi în vremea lui Ahmed III (17031730) şi de parale din timpul sultanilor Mahmud I (1730-1754), Mustafa III (17571774) şi Abdul Hamid I (1774-1789) ${ }^{153}$.

Periodizarea acestor necropole de pe teritoriul localității Nufăru, propusă în anii ' 80 de colectivul de cercetare de atunci a

\footnotetext{
145 Vasiliu 1996, 230-233, 240-242, pl. IV-VI.

${ }^{146}$ Este posibil ca descoperirile de la Sarichioi să intre în această categorie.

${ }^{147}$ Micu et alii, 210.

${ }^{148}$ Materiale inedite din colecțiile ICEM Tulcea (informație Aurel Stănică).

${ }^{149}$ Custurea 1986, 300.

150 Stănică et alii 2005-2006, 319-321, 323 şi n. 23.

151 Vasiliu 1995, 374-375.

152 Micu et alii 2006, 210.

${ }^{153}$ Custurea 1986, 300-301.
}

sitului ${ }^{154}$, şi anume identificarea necropolelor secolelor X-XI în partea de sud şi de vest a satului, a celei din secolele XI-XII în zona nordică a promontoriului şi a celei din ultima parte de existență a aşezării, până la mijlocul secolului al XIII-lea, imediat la sud de zidul de incintă de pe str. Bisericii, a fost confirmată doar parțial de cercetările ulterioare, fără a se putea face însă prea multe precizări suplimentare. În orice caz, pentru perioada de început a aşezării, sfârşitul secolului al X-lea-prima jumătate a secolului al XI-lea, descoperirile arheologice ale anilor 90 ai secolului al XX-lea şi ai începutului secolului al XXI-lea nu au adus nici o noutate pentru partea de vest a satului, putându-se doar sugera, prin descoperirile din curtea dispensarului uman şi de pe proprietatea Popa, o grupare a mormintelor încadrabile în această perioadă în apropierea zidului de incintă estic. Pentru perioada funcționării cetății dincolo de mijlocul secolului al XI-lea până la mijlocul secolului al XIII-lea, cercetările desfăşurate în special în zona nordică a promontoriului nufărean au însemnat un supliment important de informație, cercetându-se până în prezent în cele două puncte definind aceeaşi necropolă, Piatră şi Trecere bac - un număr de 265 de complexe funerare. În plus, în campania 2005 a putut fi precizat încă un orizont funerar pe latura de est a cetății, reprezentat de mormintele cercetate pe proprietatea Ducica, eventual databile la sfârşitul secolului al XII-lea-prima jumătate a secolului al XIII-lea, şi care ar putea fi legate de segmentul de necropolă identificat în 1980 pe proprietatea Drăgan. Ipoteza că zonele conţinând complexe funerare de pe laturile de est şi de sud ale fortificației bizantine formează de fapt o singură necropolă, emisă

\footnotetext{
154 Baraschi, Moghior 1984-1985, 149; MănucuAdameșteanu, Mănucu-Adameșteanu 1986, 211-212; Mănucu-Adameşteanu 1991a, 515-516, MănucuAdameşteanu 1998, 82, Damian et alii 2003a, 242, n. $40-45$.
} 
deja pentru secolele XVIII-XIX ${ }^{155}$, credem că este plauzibilă mai degrabă pentru perioada medio-bizantină, mai precis pentru secolele XII-XIII. Cercetările desfăşurate în 2006 în partea de sud a satului, la sud de „zidul-baraj” din punctul Râpă, nu au confirmat existența în această zonă a unei necropole ce ar fi functionat aici în secolul al XI-lea ${ }^{156}$; în schimb au documentat prezența unei întinse necropole moderne.

\section{Sinteză preliminară a caracteristicilor antropologice ale materialului studiat}

Dintre cele 162 de complexe funerare menţionate, ne-au fost accesibile pentru studiul antropologic doar 118. În urma analizei, a fost identificat un număr minim de 163 indivizi.

Sexul a fost determinat pe baza metodelor propuse de Acsádi şi Nemeskéry ${ }^{157}$, urmărindu-se în principal diferențele sexuale generale întâlnite la nivelul craniului şi pelvisului ${ }^{158}$, precum şi diferențe sexuale evidentiate pe baza principalelor caracteristici morfoscopice şi biometrice ale oaselor lungi. În urma determinării acestui parametru, au fost identificați 109 indivizi $(66,87 \%)$. Sexul feminin este mai bine reprezentat - 60 de indivizi $(55,04 \%$ din total) față de 49 de bărbați (44,95 \%). În 47 de cazuri, raportat la numărul total de indivizi (163), avem de-a face cu copii $(28,83 \%)$, iar în şapte cazuri $(4,42 \%)$ sexul nu a putut fi stabilit.

În vederea estimării vârstei, pentru subiecții adulți am utilizat metoda propusă de

\footnotetext{
${ }^{155}$ Mănucu-Adameşteanu, Mănucu-Adameşteanu 1986, 211, n. 7.

${ }^{156}$ Susținută de Gh. Mănucu-Adameșteanu (MănucuAdameşteanu, Mănucu-Adameşteanu 1986, 211-212 şi fig. 1; Mănucu-Adameşteanu 1991a, 515; 1998, 82). ${ }^{157}$ Acsádi, Nemeskéry 1970, 75-100.

158 În vederea evidențierii caracteristicilor sexuale specifice au fost utilizate grade de sexualizare, marcate cu ,-" (subiecți de sex feminin), ,+" (indivizi de sex masculin) sau "0" (indivizi incerți din punct de vedere sexual). În acest caz ne-am folosit numai de glabelă, procese mastoide, şanţuri sciatice şi unghiuri pubiene.
}

Acsádi şi Nemeskéry ${ }^{159}$. Pentru aceasta, ne-am servit doar de schimbările observate la nivelul suprafeței simfizare pubice şi resorbția țesutului spongios din epifizele proximale ale humerusului şi femurului, examinată prin secțiuni sagitale ${ }^{160}$. În cazul grupelor infans I, infans II şi juvenis, vârsta a fost estimată după Ubelaker ${ }^{161}$, pe baza erupției dentare, precum şi pe baza lungimilor maxime ale oaselor lungi sau fuziunii epifizelor la diafize ${ }^{162}$. Repartizarea pe categorii de vârstă a fost făcută după Maximilian ${ }^{163}$. Categoriile de vârstă cărora aparțin sunt: infans I (33 $20,24 \%)$, infans II $(9-5,52 \%)$, juvenis (3 $1,84 \%)$, adultus (5 - 3,06\%), maturus I (14 $8,58 \%)$, maturus II $(21-12,88 \%)$ şi senilis I $(33-20,24 \%)$. În 45 de cazuri $(27,60 \%$ din totalul indivizilor), categoriile de vârstă sunt incerte: infans $\mathrm{I} /$ infans II $(4-2,45 \%)$, infans II/juvenis $(1-0,61 \%)$, juvenis/adultus (4 $2,45 \%)$, juvenis/adult ( $8-4,90 \%)$, adultus/ adult $(21-12,88 \%)$ sau adulți $(7-4,29 \%)$.

Taliile au fost estimate în cazul adulților după Rösing ${ }^{164}$, pe baza lungimilor maxime ale humerusurilor, radiusurilor, femurelor şi tibiilor. Atunci când am avut dea face cu copii şi am beneficiat şi de femure, statura a fost estimată ținându-se cont de modelul lui Olivier ${ }^{165}$. Repartiția taliei pe grupe a fost realizată după Necrasov şi colaboratorii săi ${ }^{166}$. Taliile au fost estimate în 78 de cazuri $(47,56 \%)$, atât pentru indivizii adulți $(65-83,33 \%)$, cât şi în cazul copiilor (13 - 16,66\%). În această din urmă situație, taliile nu au fost încadrate pe categorii. Aşadar, în cadrul ambelor sexe, taliile sunt mici $(16-24,61 \%)$, submijlocii $(20-$

\footnotetext{
${ }^{159}$ Acsádi, Nemeskéry 1970, 122-135.

160 Vârsta corespunzătoare a fost stabilită pe baza fazelor în care se încadrează cei trei indicatori.

${ }^{161}$ Ubelaker 1978, 45-53.

162 În cadrul repartizării pe categorii, în cazul copiilor, am luat în considerare doar vârsta dentară. Atunci când dinții nu au fost prezenți, am considerat vârsta obținută pe baza lungimilor maxime ale oaselor lungi.

${ }_{163}$ Maximilian 1962, 90-91.

${ }^{164}$ Rösing 1988, 597.

${ }^{165}$ Olivier 1960, 259.

${ }^{166}$ Necrasov et alii 1959, 28.
} 
30,76\%), mijlocii (9 - 13,84\%), supramijlocii $(13-20 \%)$ şi mari $(7-10,76 \%)$. Pe sexe, atât femeile cât şi bărbații sunt încadrați în toate categoriile, fără excepție.

$\mathrm{Au}$ fost evidențiate şi câteva caractere non-metrice, atât la nivelul scheletului cranian, cât şi la nivelul scheletului postcranian: suturi metopice (în două cazuri), oase wormiene în principal în jurul punctului $\lambda$ (3) şi foramenuri olecraniene la nivelul humerusurilor (într-un singur caz).

De asemenea, dintre principalele dimensiuni şi principalii indici cranieni au fost examinate doar diametrul anteroposterior maxim ( $\mathrm{g}$-op), diametrul transversal maxim (eu-eu) şi indicele cranian orizontal aferent ${ }^{167}$. Se remarcă, aproximativ în aceeaşi măsură, predominanța craniilor dolicocrane (= alungite, 5$)$, mezocrane (= medii, 7) sau brahicrane (= rotunjite, 6$)$. Într-un singur caz avem de a face cu un craniu hiperbrahicran (= foarte rotund).

Din punct de vedere patologic, am semnalat prezența cariilor (la 19 indivizi), edentațiilor $^{168}$ (12) şi exostozelor ${ }^{169}(8)$, care afectează atât femeile, cât şi bărbații, iar întrun singur caz, hyperostoza porotica ${ }^{170}$ (la un copil). De asemenea, în două cazuri avem de a face cu discontinuități osoase, probabil rezultat al unor fracturi vindecate, iar într-un caz cu fenomenul de pseudoplagiocefalie ${ }^{171}$.

\section{Catalogul complexelor funerare}

167 Din cauza faptului că în acest studiu nu ne-am propus şi efectuarea de restaurări craniene, ne-am limitat doar la examinarea acestora.

${ }^{168}$ Lipsa totală sau parțială a dinților, cauzată probabil de paradontoză — proces patologic al paradonțiului (țesuturile în care sunt fixați dinții), constând în retracția gingiilor.

${ }^{169}$ Formarea unui os nou pe suprafața osului.

170 Maladie ce se manifestă atât prin modificări ale morfologiei externe a osului, cauzate de fenomene de resorbție şi remaniere osoasă, cât şi prin modificări ale structurii interne osoase, datorate acumulării de sinusuri sau spații medulare osoase adiționale, care duc la creşterea țesutului spongios în detrimentul celui compact (Miritoiu 1992, 5).

171 Deformare a craniului ce poate fi cauzată de presiunea pământului sau poate constitui obiectul unor decalcifieri osoase (Brothwell 1981, 172-173). cercetate şi recuperate în intravilanul localității Nufăru

Abrevieri: M - mormânt; S - secțiune; Sup. - suprafață; c. - carou; L - lungime; 1 lățime; d - diametru, gr - grosime; cpl. - complex

\section{Partea de vest a satului}

1) Numeroase schelete, unele cu brățări de sticlă, databile în epoca medio-bizantină (sec. XXI); descoperite în vecinătatea complexului de cuptoare, 1982; deranjate de intervenții moderne;

\section{Partea de est a satului}

2) M / Str. Lacului, proprietatea Ilie Odică, 1992 - schelet uman recuperat; fără context arheologic; fără inventar; încadrare cronologică probabilă: epoca modernă; caracteristici antropologice: prezintă craniu (glabelă grad +1 , diametru antero-posterior maxim 169,84 mm foarte scurt, diametru transversal maxim 142,31 mm îngust, indice cranian orizontal 83,79 brahicran, deformat la nivelul occipitalului, pseudoplagiocefalie), mandibulă (unghiuri mandibulare şi menton grad +1$)$, humerus stâng (Lmax $=303,54 \mathrm{~mm}$, faza II), coxal stâng (lipsă fragmente de ilion, şanț sciatic grad +1 , fațetă simfizară pubică faza II), femur stâng (jumătate distală), femur drept $(\operatorname{Lmax}=422,84 \mathrm{~mm}$, linea aspera relativ bine evidenţiată, faza II) şi tibii $(\mathrm{Lmax}=342,44 \mathrm{~mm} / 343,12 \mathrm{~mm})$; sex: masculin; vârstă: cca. 46,33 ani, maturus II; talie: cca. 158,18 cm, mică; fig. 30/1;

\section{STRADA TURNULUI}

3) M 1 / Str. Turnului = punctul Şcoală, 1982, S 1, c. 5 - mormânt de inhumație; adâncime minimă $-0,25 \mathrm{~m}$ față de nivelul actual de călcare; orientare $\mathrm{V}-\mathrm{E}$; distrus în mare parte; schelet probabil de adult, posibil în decubit dorsal, din care se păstrează doar oasele picioarelor care pătrund în malul estic; L surprinsă în secțiune $-0,25 \mathrm{~m}$; fără inventar în porțiunea cercetată; lespezi pe mormânt; încadrare cronologică probabilă: epoca mediobizantină (post sec. XI); fig. 7;

4) $\mathrm{M} 2$ / Str. Turnului = punctul Şcoală, 1982, S 1, c. 9, lângă malul V - mormânt de inhumație; adâncime minimă $-0,75 \mathrm{~m}$ față de nivelul actual de călcare; orientare $\mathrm{V}-\mathrm{E}$; distrus în mare parte; schelet probabil de adult, posibil în 
decubit dorsal, din care se păstrează doar oasele bazinului şi ale picioarelor; fără inventar în porțiunea cercetată; lespezi pe mormânt; încadrare cronologică probabilă: epoca medio-bizantină (post sec. XI); fig. 7;

5) $\mathrm{M} 3$ / Str. Turnului = punctul Şcoală, 1982, S 1, c. 5 - mormânt de inhumație; adâncime minimă $-0,35 \mathrm{~m}$ față de nivelul actual de călcare; orientare V-E; schelet probabil de adult, posibil în decubit dorsal, pătrunzând în malul $\mathrm{V}$, vizibil până în dreptul rotulelor, antebraţul drept deranjat, părând îndoit spre piept; L surprinsă în secțiune $0,80 \mathrm{~m}$; fără inventar în porțiunea cercetată; lespezi pe mormânt; încadrare cronologică probabilă: epoca medio-bizantină (post sec. XI); fig. $7 ; 8 / 3$

6) $\mathrm{M} 4$ / Str. Turnului = punctul Şcoală, 1982, S 1, c. 7 - mormânt de inhumație; adâncime minimă $-0,50 \mathrm{~m}$ față de nivelul actual de călcare; orientare V-E; schelet probabil de adult, bine păstrat, în decubit dorsal, ale cărui tibii şi peronee pătrund în malul $\mathrm{E}$; antebrațul drept pe abdomen, antebrațul stâng pe bazin; L surprinsă în secțiune 1,15 m; fără inventar în porțiunea cercetată; lespezi pe mormânt; încadrare cronologică probabilă: epoca medio-bizantină (post sec. XI); fig. 7; 8/4;

7) M 5 / Str. Turnului = punctul Şcoală, 1982, S 1, c. 3 - mormânt de inhumație; adâncime minimă $-0,60$ m față de nivelul actual de călcare; orientare V-E; schelet probabil de adult, în decubit dorsal, din care sunt vizibile oasele picioarelor, restul scheletului pătrunzând în malul V; fără inventar în porțiunea cercetată; încadrare cronologică probabilă: epoca medio-bizantină (post sec. XI); fig. 7; 8/5;

8) M 6 / Str. Turnului = punctul Şcoală, 1982, S 1, c. 5, lângă malul E - mormânt de inhumație; adâncime minimă $-0,35 \mathrm{~m}$ față de nivelul actual de călcare, între M 1 şi M 3; orientare V-E; schelet probabil de adult, în decubit dorsal, ale cărui femure pătrund în malul E; făă inventar în porțiunea cercetată; încadrare cronologică probabilă: epoca medio-bizantină (post sec. XI); fig. 7;

9) M 7 / Str. Turnului = punctul Şcoală, 1982, S 1, c. 4, sub M 1 - mormânt de inhumație; adâncime minimă $-0,50 \mathrm{~m}$ față de nivelul actual de călcare; orientare V-E; schelet probabil de adult; posibil în decubit dorsal; se păstrează craniul şi un os al mâinii stângi sub femurele lui M 1; L surprinsă în secțiune $-0,15 \mathrm{~m}$; fără inventar în porțiunea cercetată; încadrare cronologică probabilă: epoca medio-bizantină (post sec. XI); fig. 7;

10) $\mathrm{M} 8$ / Str. Turnului = punctul Şcoală, 1982, S 1, c. 10, la S de M 2 - mormânt de inhumație; adâncime minimă $-0,45 \mathrm{~m}$ față de nivelul actual de călcare; orientare V-E; schelet probabil de adult ce pătrunde în malul $\mathrm{V}$; fără inventar în porțiunea cercetată; încadrare cronologică probabilă: epoca medio-bizantină (post sec. XI); fig. 7;

11) M 9 / Str. Turnului = punctul Şcoală, 1982, S 1, c. 10, la S de M 8 - mormânt de inhumație; adâncime minimă $-0,70-0,95 \mathrm{~m}$ față de nivelul actual de călcare; orientare V-E; schelet probabil de adult ale cărui femure pătrund în malul V; făă inventar în porțiunea cercetată; încadrare cronologică probabilă: epoca medio-bizantină (post sec. XI); fig. 7;

12) M 10 / Str. Turnului = punctul Şcoală, 1982, S 1, c. 8, la N de M 2 - mormânt de inhumație; adâncime minimă $-0,75 \mathrm{~m}$ față de nivelul actual de călcare; orientare V-E; schelet probabil de adult, cu craniul lângă malul $\mathrm{V}$; fără inventar în porțiunea cercetată; încadrare cronologică probabilă: epoca medio-bizantină (post sec. XI); fig. 7;

13) M 11 / Str. Turnului = punctul Şcoală, 1982, S 1, c. 6 - mormânt de inhumație; adâncime minimă $-0,60$ m față de nivelul actual de călcare; orientare V-E; craniu, probabil de adult lângă malul $\mathrm{E}$; fără inventar în porțiunea cercetată; încadrare cronologică probabilă: epoca medio-bizantină (post sec. XI); fig. 7;

14) $M 12$ / Str. Turnului = punctul Şcoală, 1982, S 1, c. 5 - mormânt de inhumație; adâncime minimă $-0,55 \mathrm{~m}$ față de nivelul actual de călcare; orientare V-E; schelet probabil de adult, în decubit dorsal, din care sunt vizibile doar bazinul şi oasele membrelor inferioare, restul pătrunzând în malul V; fără inventar în porțiunea cercetată; încadrare cronologică probabilă: epoca medio-bizantină (post sec. XI); fig. 7;

15) M $1 /$ Str. Turnului $=$ punctul Dispensar, 1983, S 1, c. 7 - mormânt de inhumație; adâncime minimă $-2,90 \mathrm{~m}$ față de nivelul actual de călcare; orientare V-E; schelet probabil de adult, în decubit dorsal, posibil femeie, din care este vizibilă doar partea superioară, până la jumătatea toracelui, restul pătrunzând în malul E; L 
surprinsă în secțiune $-0,50 \mathrm{~m}$; fără inventar în porțiunea cercetată; casetă de piatră de formă trapezoidală, Lcasetă în secțiune $=0,90$; leasetă $=$ cca. 1,20 m, mai lată în zona capului; încadrare cronologică: epoca medio-bizantină (sec. X-XI); fig. 9;

16) $\mathrm{M} 2$ / Str. Turnului = punctul Dispensar, 1983, S 1, c. 4 - mormânt de inhumație; adâncime minimă $-3,10$ m față de nivelul actual de călcare; orientare V-E; schelet probabil în decubit dorsal, vizibil până la rotule, restul fiind distrus de o groapă menajeră; antebrațul drept pe piept, antebrațul stâng pe abdomen, deasupra bazinului; L surprinsă în secțiune $-1 \mathrm{~m}$; fără inventar în porțiunea cercetată; încadrare cronologică: epoca medio-bizantină (sec. X-XI); caracteristici antropologice: prezintă craniu (lipsă fragmente de parietal şi frontal stâng, frunte joasă, rotunjită, diametru antero-posterior maxim 171,95 mm mijlociu, diametru transversal maxim 137,14 mm îngust, indice cranian orizontal 79,75 mezocran), mandibulă (unghiuri mandibulare şi menton grad 1), clavicule $(\operatorname{Lmax}=128,52 \mathrm{~mm} / 124,50 \mathrm{~mm})$, scapule (fragmente de corpuri şi cavităţi glenoide), humerus stâng (diafiză), humerus drept (Lmax = $247,65 \mathrm{~mm}$, faza III), radius stâng (jumătate distală), radius drept $(\operatorname{Lmax}=189,35 \mathrm{~mm})$, ulnă stângă $(\operatorname{Lmax}=212,67 \mathrm{~mm})$, ulnă dreaptă (lipsă epifiză proximală), vertebre (fragmente de corpuri şi apofize), coaste, stern (un fragment de manubriu), coxal stâng (un fragment de pubis, fațetă simfizară pubică faza IV), femure (lipsă capete femurale, faza III), metacarpiene şi falange; sex: feminin; vârstă: cca. 54,33 ani, senilis I; talie: cca. $140,23 \mathrm{~cm}$, mică; elemente de patologie: carii la nivelul premolarilor 1 inferiori, edentație în zona molarilor 1 şi 2 inferiori stânga; fig. 9;

17) $\mathrm{M} /$ Str. Turnului 199, proprietatea Oana Cristina Popa, 2005, casetă, sub nivelul locuinței cu bază de piatră, la baza nivelului de pământ cenuşiu gălbui - mormânt de inhumație; adâncime față de nivelul actual de călcare $-2,30 \mathrm{~m}$; orientare $\mathrm{V}-\mathrm{E}$; schelet în decubit dorsal; craniul aplecat pe partea stângă, pătrunzând cu jumătatea sa dreaptă în malul sudic; adâncimea mare la care a apărut mormântul nu a permis realizarea unei casete pentru extragerea integrală a scheletului, recuperându-se, prin secționare longitudinală, doar partea sa stângă,; L surprinsă în casetă - 1,45 m; fără inventar în porțiunea cercetată; încadrare cronologică: epoca medio-bizantină (sec. X-XI); caracteristici antropologice: prezintă craniu (lipsă fragmente de parietal drept, pereți cranieni groşi, frunte înaltă, retrasă, occipital puternic bombat la nivelul solzului, locuri de inserție musculară puternic dezvoltate, diametru antero-posterior maxim 166,14 $\mathrm{mm}$ foarte scurt, diametru transversal maxim 134,55 $\mathrm{mm}$ foarte îngust, indice cranian orizontal 80,98 brahicran), mandibulă (menton grad +2 ), clavicule (jumătăti mediale), scapulă (trei fragmente), radius stâng (treime distală şi un fragment de diafiză), radius drept (lipsă treime proximală), ulnă stângă (epifiză distală), ulnă dreaptă $(\operatorname{Lmax}=260,58$ $\mathrm{mm}$ ), vertebre (fragmente de corpuri şi apofize), coaste, stern (corp), sacrum (două fragmente), coxal stâng (ilion fragmentar, fațetă simfizară pubică faza IV), femur stâng $(\operatorname{Lmax}=425,30 \mathrm{~mm}$, linea aspera bine evidențiată, faza IV), tibie stângă (Lmax $=360,61 \mathrm{~mm}$ ), fibulă stângă (treime distală şi un fragment de diafiză), metacarpiene, metatarsiene şi falange; sex: masculin; vârstă: cca. 59 ani, senilis I; talie: cca. 159,94 cm, mică; elemente de patologie: carii bilaterale la nivelul molarilor 1 şi 2 inferiori, discontinuitate osoasă la nivelul treimii distale ulnare drepte, ce trădează probabil o fractură (vindecată); fig. 8/6; 9;

\section{STRADA C-TIN. DOBROGEANU GHEREA}

18) M 1 / Str. C-tin. Dobrogeanu Gherea, proprietatea D. Ducica, 2005, S 1, c. 6/7 mormânt de inhumație, adâncime minimă față de nivelul actual de călcare $-0,44 \mathrm{~m}$; orientare SV$\mathrm{NE}$; schelet în decubit dorsal, craniul distrus, rămasă in situ doar mandibula; antebrațul drept pe piept, antebrațul stâng deasupra bazinului; L scheletului în groapă $=1,60 \mathrm{~m}$, fără craniu, Lfemur $=0,39 \mathrm{~m}$; fără inventar; încadrare cronologică: epoca medio-bizantină (sec. XII-XIII); caracteristici antropologice: prezintă craniu (lipsă fragmente de viscerocraniu, diametru anteroposterior maxim $176,98 \mathrm{~mm}$ scurt, diametru transversal maxim 145,10 mm îngust, indice cranian orizontal 81,98 brahicran, sutură metopică), mandibulă (unghiuri mandibulare şi menton $\operatorname{grad}+1)$, clavicule $(\operatorname{Lmax}=155,58$ $\mathrm{mm} / 154,86 \mathrm{~mm}$ ), scapule (aproximativ întregi), humerusuri $(\operatorname{Lmax}=316,65 \mathrm{~mm} / 315,94 \mathrm{~mm}$, faza II), radiusuri (Lmax $=231,92 \mathrm{~mm} / 237,45 \mathrm{~mm}$, asimetrie), ulne (Lmax $=251,92 \mathrm{~mm} / 258,03 \mathrm{~mm}$, asimetrie), vertebre, coaste, stern (fragmentar), 
sacrum (fațete articulare ce se întind până în dreptul segmentului al treilea), coxale (şanţuri sciatice şi unghi pubian grad +1 , faţete simfizare pubice faza II), femure (Lmax $=439,26$ $\mathrm{mm} / 439,38 \mathrm{~mm}$, linea aspera bine dezvoltată, faza II), tibii (Lmax $=345,08 \mathrm{~mm} / 345,29 \mathrm{~mm})$, rotule, fibulă stângă $(\operatorname{Lmax}=333,97 \mathrm{~mm})$, fibulă dreaptă (lipsă fragmente de epifiză proximală), metacarpiene, metatarsiene şi falange; sex: masculin; vârstă: cca. 46,33 ani, maturus II; talia: cca. 160,74 cm, submijlocie; elemente de patologie: carie la nivelul molarului 2 inferior stânga, exostoze la nivelul epifizelor proximale ulnare şi coloanei vertebrale lombare; fig. 10; $11 / 3$;

19) M 2 / Str. C-tin. Dobrogeanu Gherea, proprietatea D. Ducica, 2005, Sup., c. 5/6, lângă marginea estică a suprafeței - mormânt de inhumaţie, adâncime minimă $-0,26 \mathrm{~m}$ față de nivelul actual de călcare; orientare V-E; schelet în decubit dorsal, parțial distrus de rădăcinile unui butuc de vie; craniul foarte distrus, jumătatea inferioară a coloanei vertebrale de asemenea, ca şi jumătatea dreaptă a bazinului; femurul stâng distrus; antebrațul drept pe bazin, antebrațul stâng pe piept, dar foarte deranjat - un os pe sub coaste, celălalt aşezat normal, deasupra coastelor; L scheletului în groapă $=1,33 \mathrm{~m}$, fără craniul distrus, Lfemurului $=0,37 \mathrm{~m}$; urme de cărbune sub brațul stâng; inventar: monedă de bronz follis din secolul al XI-lea, pe coxalul stâng; încadrare cronologică: epoca medio-bizantină (sec. XII-XIII); caracteristici antropologice: prezintă clavicule $(\operatorname{Lmax}=134,87 \mathrm{~mm} / 128,66 \mathrm{~mm}$, groase, locuri de inserție musculară evidente, asimetrie), scapule (fragmentare), humerusuri $($ Lmax $=285,03 \mathrm{~mm} / 288,39 \mathrm{~mm}$, faza III), radiusuri (jumătăți proximale), ulne (jumătăți proximale), coxal stâng (ilion şi cavitate acetabulară, şant sciatic grad -1), femur stâng (epifiză distală), femur drept (lipsă epifiză proximală), tibii $(\operatorname{Lmax}=329,09 \mathrm{~mm} / 327,71$ $\mathrm{mm})$, fibule $(\operatorname{Lmax}=323,07 \mathrm{~mm} / 322,96 \mathrm{~mm})$, metatarsiene şi falange; sex: feminin; vârstă: cca. 57 ani, senilis I; talie: cca. 149,94 cm, submijlocie; fig. 10; 11/5-6;

20) M 3 / Str. C-tin. Dobrogeanu Gherea, proprietatea D. Ducica, 2005, Sup., c. 6 b, lângă marginea nordică a suprafeței, la N de M 2 mormânt de inhumație, adâncime minimă $-0,35 \mathrm{~m}$ față de nivelul actual de călcare; orientare V-E; schelet în decubit dorsal; craniul aşezat pe partea stângă; coloana în formă de S, picioarele puternic curbate, antebrațul drept pe bazin, antebrațul stâng cu palma răsfirată pe partea dreaptă a bazinului; distrus de rădăcinile viței de vie; L scheletului în groapă = 1,33 m; fără inventar; încadrare cronologică: epoca medio-bizantină (sec. XII-XIII); caracteristici antropologice: prezintă craniu (fragmentar), claviculă dreaptă ( Lmax $=146,88$ mm), scapule (lipsă câteva fragmente de la nivelul corpurilor), humerusuri ( $\max =331,85$ $\mathrm{mm} / 332,12 \mathrm{~mm})$, radius stâng $(\operatorname{Lmax}=243,09$ $\mathrm{mm})$, radius drept $(\operatorname{Lmax}=243,84 \mathrm{~mm})$, ulne $($ Lmax $=270,98 \mathrm{~mm} / 271,02 \mathrm{~mm})$, vertebre, coaste, stern (trei fragmente de corp), sacrum, coxale, femure (diafize şi epifize sparte), tibii (diafize şi epifize sparte), rotulă stângă, fibulă stângă (diafiză), metacarpiene, metatarsiene şi falange; sex: masculin (oase lungi de dimensiuni mari, puternice); vârstă: cca. 19 ani, juvenis (humerusuri epifizate distal, radius stâng şi ulne epifizate proximal, restul epifizelor nefuzionate); fig. 10;11/7-8;

21) M 4 / Str. C-tin. Dobrogeanu Gherea, proprietatea D. Ducica, 2005, Sup., c. 7 b, lângă marginea vestică a suprafeței, la N de M 2 mormânt de inhumație, adâncime minimă $-0,42 \mathrm{~m}$ față de nivelul actual de călcare; orientare SV-NE; schelet în decubit dorsal; craniul cu orbitele în sus, uşor aplecat pe partea dreaptă; scheletul deranjat probabil de vița de vie; antebrațul drept lipseşte, antebrațul stâng pe lângă corp; picioarele deranjate: dreptul deplasat spre sud şi aşezat oblic, stângul deplasat spre sud; L scheletului în groapă $=0,90 \mathrm{~m}$, fără craniu, $\mathrm{L}$ femurului $=0,18 \mathrm{~m}$; inventar: 2 cercei tip verigă simplă, bronz; $d=15$ mm; ICEM, inv. 47036-47037; încadrare cronologică: epoca medio-bizantină (sec. XII-XIII); caracteristici antropologice: prezintă craniu (câteva fragmente de calotă craniană, un fragment de orbită stângă, un fragment de sfenoid), claviculă stângă (Lmax $=73,62 \mathrm{~mm})$, scapule (aproximativ întregi), humerus stâng (Lmax $=138,49 \mathrm{~mm}$ ), humerus drept (lipsă epifiză proximală), ulnă dreaptă $(\operatorname{Lmax}=118,43 \mathrm{~mm})$, vertebre, coaste, sacrum (S1 şi S2), coxale (ilioane), femure (Lmax $=190,87 \mathrm{~mm} / 191,91 \mathrm{~mm})$, tibii $(\operatorname{Lmax}=156,77$ $\mathrm{mm} / 156,85 \mathrm{~mm})$, fibule $(\mathrm{Lmax}=154,98$ $\mathrm{mm} / 155,00 \mathrm{~mm})$, metacarpiene, metatarsiene şi falange; vârstă: cca. 2,5-3,5 ani, infans I (după lungimile maxime ale oaselor lungi); talie: cca. 
109,5 cm; fig. 10; 11/4;

22) M 5 / Str. C-tin. Dobrogeanu Gherea, proprietatea D. Ducica, 2005, Sup. Ducica, c. 6 b - mormânt de inhumație, câteva oase umane la sud de M 3; fără inventar în porțiunea cercetată; încadrare cronologică: epoca medio-bizantină (sec. XII-XIII); caracteristici antropologice: prezintă femur stâng (Lmax $=419,30 \mathrm{~mm}$, epifize mici, subțire, gracil, linea aspera slab evidențiată, faza III); sex: feminin; vârstă: cca. 52 ani, senilis I; talie: cca. 153,36 cm, mijlocie; fig. 10; 11/8;

23) M 6 / Str. C-tin. Dobrogeanu Gherea, proprietatea D. Ducica, 2005, S 1, c. 6 - mormânt de inhumație, vizibile câteva oase umane ce pătrund parțial în malul sudic; fără inventar în porțiunea cercetată; încadrare cronologică: epoca medio-bizantină (sec. XII-XIII); caracteristici antropologice: prezintă craniu (un fragment de orbită, maxilar stâng), hemimandibulă dreaptă (lipsă ram vertical), humerus stâng (Lmax = 292,55, faza II), vertebre (patru cervicale), coxal stâng (şanț sciatic grad -1 , fațetă simfizară pubică faza II), femur stâng ( $\operatorname{Lmax}=398,68$, linea aspera slab evidențiată, faza II), tibie stângă $(\operatorname{Lmax}=334,59 \mathrm{~mm})$, fibulă stângă $(\operatorname{Lmax}=$ $327,01 \mathrm{~mm})$, calcaneu stâng şi falange; sex: feminin (oase gracile, subțiri); vârstă: cca. 46,33 ani, maturus II; talie: cca. $150,16 \mathrm{~cm}$, submijlocie; elemente de patologie: carie la unul dintre canini, edentație în zona premolarului 1-molari inferiori;

\section{Partea de sud a satului}

24) M 1 / Str. C-tin. Dobrogeanu Gherea, în dreptul intersecției cu Str. Bisericii, 2006, şanț pentru alimentarea cu apă pe latura sudică a străzii - mormânt de inhumație în zona stâlpului din dreptul proprietății Ştefan Mocanu, sub nivelul străzii; orientare probabilă V-E, paralelă cu axul străzii, explicație pentru dislocarea fără urme pe profilurile şanțului; oase umane recuperate; încadrare cronologică: epoca modernă; caracteristici antropologice: resturi osteologice ce provin de la doi indivizi: 1) prezintă craniu (diametru anteroposterior maxim 168,99 $\mathrm{mm}$ scurt, diametru transversal maxim $125,92 \mathrm{~mm}$ foarte îngust, indice cranian orizontal 74,51 dolicocran), scapulă dreaptă (lipsă fragmente corp), vertebre, coaste şi tibie dreaptă $(\operatorname{Lmax}=294,90 \mathrm{~mm})$; sex: feminin; categorie de vârstă: adult (uzură dentară puternică); talie: cca. 142,90 cm, mică; 2) prezintă craniu (un fragment de parietal) şi femur drept $(\operatorname{Lmax}=137,98 \mathrm{~mm})$; vârstă: cca. $0,5-1,5$ ani, infans I (după lungimea maximă a femurului); talie: cca. 84,5-87 cm;

25) M 2 / Str. C-tin. Dobrogeanu Gherea, în dreptul intersecției cu Str. Bisericii, 2006, şanț pentru alimentarea cu apă pe latura sudică a străzii; casetă practicată în malul $\mathrm{S}$ al şanţului pentru alimentarea cu apă - mormânt de inhumație în zona stâlpului din dreptul proprietății Ştefan Mocanu (Str. Bisericii 188); adâncime minimă $-0,40$ m față de nivelul actual de călcare; orientare probabilă V-E; mormânt deranjat (reînhumare?) probabil în momentul amenajării străzii; grupaj de oase umane; L în groapă - 0,42 m; inventar: monedă de argint otomană, descoperită în gura scheletului; încadrare cronologică: epoca modernă; caracteristici antropologice: prezintă craniu (fragmentar), hemimandibulă dreaptă, claviculă dreaptă, scapulă stângă (aproximativ întreagă), scapulă dreaptă, humerus drept $(\operatorname{Lmax}=181,65 \mathrm{~mm})$, ulnă stângă $(\operatorname{Lmax}=147,45 \mathrm{~mm})$, ulnă dreaptă (jumătate proximală), vertebre, coaste, sacrum (fragmentar), femure $(\operatorname{Lmax}=264,57 \mathrm{~mm} / 264,37 \mathrm{~mm})$, tibie dreaptă $(\operatorname{Lmax}=210,07 \mathrm{~mm})$, metatarsiene şi falange; vârstă: cca. 7 ani, infans $\mathrm{I} /$ infans II (molarii 1 superiori şi inferiori ieşiţi), cca. 6-7,5 ani, infans I/infans II (după lungimile maxime ale oaselor lungi); talie: cca. 130,25-133,25 cm; au mai fost identificate o claviculă $(\operatorname{Lmax}=63,90$ $\mathrm{mm}$ ), o scapulă şi coxal (ilion), toate de pe dreapta; categorie de vârstă: infans I (prin comparație dimensională cu alte oase aparținând grupei infans I); fig. 18, 22/5;

26) M 3 / Str. C-tin. Dobrogeanu Gherea, în dreptul intersecției cu Str. Bisericii, 2006; şanţ pentru alimentarea cu apă pe latura sudică a străzii; casetă practicată în malul $\mathrm{S}$ al şanțului pentru alimentarea cu apă - mormânt de inhumație în zona stâlpului din dreptul proprietății Şt. Mocanu (Str. Bisericii 188); deranjat probabil în momentul înhumării M 2; adâncime minimă $-0,48 \mathrm{~m}$ față de nivelul actual de călcare; orientare SV-NE; schelet probabil în decubit dorsal, din care se păstrează în conexiune anatomică membrele inferioare; L (parțială) în groapă (membrele inferioare) $-0,64 \mathrm{~m}$; inventar: pafta de centură, bronz, în zona bazinului; încadrare cronologică: epoca modernă; caracteristici antropologice: prezintă coxale (ilioane, ischioane), femure $(\operatorname{Lmax}=294,19$ 
$\mathrm{mm} / 292,98 \mathrm{~mm}$ ), tibii $\operatorname{Lmax}=228,17 \mathrm{~mm} / 229,71$ $\mathrm{mm})$, fibule $(\operatorname{Lmax}=226,39 \mathrm{~mm} / 226,26 \mathrm{~mm})$, metatarsiene şi falange; vârstă: cca. $6,5-8,5$ ani, infans I/infans II (după lungimile maxime ale oaselor lungi); talie: cca. $138,5 \mathrm{~cm}$; a mai fost identificat un coxal stâng (ilion); categorie de vârstă: infans I (prin comparație dimensională cu alte oase aparținând grupei infans I); fig. 18, 22/5;

27) $\mathrm{M} 4$ / Str. C-tin. Dobrogeanu Gherea, în dreptul intersecției cu Str. Bisericii, 2006, şanț pentru alimentarea cu apă pe latura nordică a străzii - mormânt de inhumație în zona stâlpului din dreptul proprietății Virgil Nichifor; orientare probabilă V-E; deranjat la săparea mecanică a şanțului; fără inventar; încadrare cronologică: epoca modernă; caracteristici antropologice: schelete ce provin de la doi indivizi: 1) prezintă craniu (diametru antero-posterior maxim 166,09 $\mathrm{mm}$, diametru transversal maxim $131,21 \mathrm{~mm}$, indice cranian orizontal 78,99 mezocran), mandibulă, claviculă dreaptă $(\operatorname{Lmax}=93,14 \mathrm{~mm})$, scapule (lipsă fragmente corp), humerus stâng $(\operatorname{Lmax}=132,23 \mathrm{~mm})$, vertebre, coaste, stern (manubriu), coxal drept (ilion) şi metatarsiene; vârstă: cca. 1,5-3,5 ani, infans I (după lungimile maxime ale oaselor lungi); elemente de patologie: hyperostoza porotica (cribra orbitalia în ambele orbite şi cribra cranii în zona intersecției suturilor sagitală şi lambdoide); 2) prezintă hemimandibulă stângă, claviculă stângă $(\operatorname{Lmax}=101,50 \mathrm{~mm})$, humerus drept $(\operatorname{Lmax}=210,11 \mathrm{~mm})$, radiusuri $(\operatorname{Lmax}=145,84 \mathrm{~mm} / 143,56 \mathrm{~mm})$, ulne $(\operatorname{Lmax}=$ $161,92 \mathrm{~mm} / 161,31 \mathrm{~mm}$ ), coxal drept (ilion), tibie stângă $(\operatorname{Lmax}=209,99 \mathrm{~mm})$, fibulă dreaptă $(\operatorname{Lmax}=208,48 \mathrm{~mm})$ şi fibulă stângă (jumătate proximală); vârstă: cca. 7 ani, infans I/infans II (după molarul 1 inferior ieşit), cca. 5,5-8,5 ani, infans $\mathrm{I} /$ infans II (după lungimile maxime ale oaselor lungi); fig. 30/2;

28)-29) latura sudică a satului, într-unul din şanţurile pentru alimentarea cu apă, 1981 - 2 morminte de inhumație, probabil de adulți, distruse parțial în momentul excavării pământului, depuse la $-1,20 \mathrm{~m}$ față de nivelul de călcare, în gropi simple; orientare $\mathrm{V}-\mathrm{E}$; inventar funerar: la unul dintre morminte s-a descoperit o brățară de sticlă; încadrare cronologică: epoca mediobizantină;

\section{STRADA BISERICII}

30) $\mathrm{M} /$ Str. Bisericii, şanț pentru alimentarea cu apă, 1981 - craniu uman recuperat, fără context stratigrafic; încadrare cronologică probabilă: epoca modernă; caracteristici antropologice: prezintă craniu (diametru anteroposterior maxim 187,80 $\mathrm{mm}$ lung, diametru transversal maxim 135,91 $\mathrm{mm}$ foarte îngust, indice cranian orizontal 72,36 dolicocran) şi mandibulă; sex: masculin (oase groase, inserţii musculare proeminente, frunte înaltă, retrasă); categorie de vârstă: probabil adult (grad relativ ridicat de obliterare a suturilor craniene); elemente de patologie: carii la nivelul premolarilor 1 şi 2 inferiori dreapta, edentații bilaterale la nivelul molarului 1; fig. 30/3;

31) $\mathrm{M} 3 /$ Str. Bisericii nr. 102, pe latura stângă a străzii, 1999 - mormânt de inhumație în decubit dorsal, uşor pe o parte, astfel că torsul apare răsucit, dar picioarele sunt în poziție normală; orientare V-E; schelet bine conservat, în decubit dorsal; $L$ vizibilă a scheletului în groapă $=$ $1,20 \mathrm{~m}$; craniul culcat pe partea dreaptă, cu toată partea superioară a corpului, antebraţul drept îndoit din cot, aşezat în afara corpului, antebrațul stâng pe bazin, vizibil doar piciorul stâng, (doar femurul), cel drept aflându-se sub malul de pământ, clavicula stângă deranjată; $\mathrm{L}$ femurului = $0,41 \mathrm{~m}, 1$ cutiei toracice $=0,26 \mathrm{~m}, 1$ bazinului $=$ $0,24 \mathrm{~m}$; groapa mormântului a fost săpată într-un pământ galben afânat; fără inventar în porțiunea cercetată; încadrare cronologică probabilă: epoca romano-bizantină; caracteristici antropologice: prezintă craniu (câteva fragmente), mandibulă (unghiuri mandibulare grad -2, menton grad -1), clavicule ( $\operatorname{Lmax}=137,58 \mathrm{~mm} / 141,49 \mathrm{~mm}$, scurte, gracile), scapule (aproximativ întregi), humerus stâng (lipsă fragmente de epifiză proximală), humerus drept $(\operatorname{Lmax}=320,45 \mathrm{~mm}$, faza II), radius stâng $(\operatorname{Lmax}=227,81 \mathrm{~mm})$, ulnă stângă $(\operatorname{Lmax}=242,60 \mathrm{~mm})$, stern (corp, foramen sternal), sacrum (larg, scurt, fațete auriculare ce se întind până în dreptul segmentului al doilea), coxale (şanțuri sciatice şi unghi pubian grad -2 , fațetă simfizară pubică faza II), femur stâng (Lmax $=437,51 \mathrm{~mm}$, faza II) şi rotulă stângă; sex: feminin; vârstă: cca. 46,33 ani, maturus II; talie: cca. $157,45 \mathrm{~cm}$, supramijlocie; elemente de patologie: exostoze la nivelul porțiunilor inferioare ale capetelor humerale;

32) M 1 - cpl. 20 / Str. Bisericii 102, la 1,20 m distanță spre $N$ faţă de extremitatea nordică a 
porții casei, 2006 - mormânt de inhumație deranjat? / grupaj de oase umane într-o zonă menajeră?, cpl. surprins pe o lungime de $6,50 \mathrm{~m}$ pe malul $\mathrm{E}$ al şanțului pentru alimentarea cu apă de pe latura vestică a străzii; adâncime şanț $-1,10 \mathrm{~m}$ față de nivelul actual de călcare; încadrare cronologică probabilă: epoca medio-bizantină (ante sec. XIII conform fragmentelor ceramice din zona menajeră); caracteristici antropologice: prezintă tibii (Lmax = $333,44 \mathrm{~mm} / 335,42 \mathrm{~mm}$ ), fibulă stângă (Lmax = $325,07 \mathrm{~mm}$ ) şi fibulă dreaptă (diafiză); sex: feminin (oase scurte, puțin masive, subțiri, suprafață gracilă, sărace în detalii anatomice); vârstă: peste 18 ani, juvenis/adult (epifize fuzionate); talie: cca. 152,17 cm, submijlocie;

33) M 2 - cpl. 24 / Str. Bisericii 99, 2006, casetă practicată în malul $\mathrm{E}$ al şanţului pentru alimentarea cu apă de pe latura vestică a străzii mormânt de inhumație, adâncime minimă $-0,28 \mathrm{~m}$ față de nivelul actual de călcare; orientare $\mathrm{V}-\mathrm{E}$; schelet în decubit dorsal; păstrată doar jumătatea superioară, partea de la bazin în jos fiind probabil distrusă de amenajarea străzii; craniul, distrus în momentul săpării şanțului cu mijloace mecanice, din care a fost recuperată mandibula; antebrațul drept întins pe lângă corp, humerusul stâng absent, antebrațul stâng pe bazin, dar pare deranjat, falangele mâinii stângi aduse pe partea dreaptă a bazinului; se păstrează doar o porțiune din femurul drept, deplasat; L în groapă $-0,80 \mathrm{~m}$; fără inventar; încadrare cronologică probabilă: epoca modernă; caracteristici antropologice: prezintă craniu (parietal drept), mandibulă (corpuri), claviculă stângă (jumătate medială), claviculă dreaptă $(\operatorname{Lmax}=134,65 \mathrm{~mm}$, scurtă, gracilă, slab arcuită), scapulă stângă (aproximativ întreagă), humerus drept (Lmax $=312,27 \mathrm{~mm}$, faza I), radius stâng (jumătate distală), radius drept $(\operatorname{Lmax}=240,46 \mathrm{~mm})$, ulnă dreaptă (jumătate proximală), vertebre, coaste, stern (corp), coxal stâng (ilion, şanț sciatic grad -2), femur drept (treime proximală, fără cap femural), metacarpiene, metatarsiene şi falange; sex: feminin; vârstă: cca. 41 ani, maturus II; talie: cca. $157,12 \mathrm{~cm}$, supramijlocie; elemente de patologie: edentaţie în dreptul molarilor 1 şi 2 inferiori stânga;

34) M 3 - cpl. 30 / Str. Bisericii 98 , la $\mathrm{N}$ de casa aflată la N de poartă, 2006, casetă practicată în malul $\mathrm{E}$ al şanțului pentru alimentarea cu apă de pe latura vestică a străzii - mormânt de inhumație; adâncime minimă $-0,47 \mathrm{~m}$ faţă de nivelul actual de călcare; orientare V-E; schelet aşezat pe partea dreaptă, bine păstrat, cu excepția craniului distrus după săparea mormântului, dar recuperat, lipsesc coastele pe partea dreaptă; antebrațul drept întins pe lângă corp, antebrațul stâng pe partea dreaptă a bazinului; picioarele flexate din genunchi; L în groapă (fără craniu) - 1,28 m; făă inventar; încadrare cronologică: epoca romano-bizantină; caracteristici antropologice: prezintă craniu (lipsă fragmente de calotă şi viscerocraniu), mandibulă (ramuri verticale, unghiuri mandibulare grad -1), claviculă dreaptă (jumătate medială), scapulă stângă (fragmentară), humerus stâng (Lmax = 280,74 mm, faza III), humerus drept (lipsă epifiză proximală şi fragmente diafizare, scurte, gracile), radius stâng ( $\operatorname{Lmax}=207,53 \mathrm{~mm}$ ), radius drept (lipsă epifiză distală), ulnă stângă (Lmax = 220,09 mm), ulnă dreaptă (lipsă epifiză distală), vertebre, coaste, sacrum (un fragment din S1), coxale (aproximativ întregi, şanţuri sciatice şi unghi pubian grad -1 , fațete simfizare pubice faza III), femur stâng (lipsă mici porțiuni de la nivelul capului femural, faza IV), femur drept (lipsă epifiză proximală, epifiză distală distrusă), rotule, fibulă stângă (lipsă epifiză distală), fibulă dreaptă (diafiză), metacarpiene, metatarsiene şi falange; sex: feminin; vârstă: cca. 55,66 ani, senilis I; talie: cca. 148,30 cm, mică; fig. 4; 6/3;

35) $M$ / Str. Bisericii 98, 2006, şanţul pentru alimentare cu apă de pe latura vestică a străzii - oase umane recuperate din zona cpl. 31 încadrare cronologică probabilă: epoca mediobizantină (sec. XI); caracteristici antropologice: prezintă o coastă, sacrum (larg, scurt, puțin arcuit), coxal drept (ilion, de dimensiuni reduse, gracil), femur stâng (Lmax $=392,31 \mathrm{~mm}$, cap femural de dimensiuni mici, faza II), femur drept (lipsă treime proximală) şi tibii (jumătăți proximale); sex: feminin; vârstă: cca. 44 ani, maturus II; talie: cca. 148,09 cm, mică;

36) M 4 - cpl. 32 / Str. Bisericii 98, 2006, la 10,80 m distanță N de M 3 (cpl. 30), şanţul pentru alimentarea cu apă de pe latura vestică a străzii - mormânt de inhumație; adâncime minimă $-0,60 \mathrm{~m}$ față de nivelul actual de călcare; orientare NV-SE; schelet în decubit dorsal, parțial distrus de şanţul vechi pentru alimentarea cu apă a gospodăriei; calota craniană, femurul drept şi tibia stângă recuperate parţial; coastele şi vertebrele deranjate; L în groapă (fără craniu) - 0,62 m; fără 
inventar; încadrare cronologică probabilă: epoca modernă; caracteristici antropologice: prezintă craniu (fragmente de calotă craniană), hemimandibulă stângă, humerus stâng (Lmax = $130,80 \mathrm{~mm}$ ), ulnă stângă (jumătate proximală), vertebre, coaste, coxale, femur stâng (Lmax = $175,31 \mathrm{~mm}$ ), femur drept (lipsă treime distală), tibie stângă (lipsă treime distală); vârstă: cca. 1-3 ani, infans I (după gradul de erupție al molarului 1 inferior), cca. 1,5-3,5 ani, infans I (după lungimile maxime ale oaselor lungi); talie: cca. 103,5 cm;

37) M 5 - cpl. 33 / Str. Bisericii 98, 2006, casetă practicată în malul E al şanțului pentru alimentarea cu apă de pe latura vestică a străzii mormânt de inhumație; adâncime minimă $-0,97 \mathrm{~m}$ faţă de nivelul actual de călcare; orientare NV-SE; schelet aşezat pe partea dreaptă, bine păstrat, cu mandibula deplasată; lipsesc o parte dintre coaste pe partea dreaptă; antebrațul drept întins pe lângă corp, antebrațul stâng deasupra părții drepte a bazinului; picioarele întinse, puțin deviate spre SE; L în groapă - 1,61 m; fără inventar; încadrare cronologică: epoca romano-bizantină; caracteristici antropologice: prezintă craniu (fragmentar), mandibulă (lipsă ramuri verticale, menton grad 0 ), claviculă dreaptă $(\operatorname{Lmax}=133,75 \mathrm{~mm})$, scapulă stângă, humerusuri (lipsă epifize proximale), radiusuri (lipsă epifize distale), vertebre, coaste, sacrum, coxale, femure $(\operatorname{Lmax}=393,92 \mathrm{~mm} / 394,32 \mathrm{~mm})$, tibii $(\operatorname{Lmax}=$ $313,21 \mathrm{~mm} / 311,78 \mathrm{~mm}$ ), fibule (lipsă epifize proximale), metatarsiene şi falange; sex: probabil masculin (dimensiuni relativ mari ale oaselor lungi); vârstă: cca. 18 ani (epifize distale humerale fuzionate, restul nu), juvenis; talie: peste $165 \mathrm{~cm}$; fig. $4 ; 6 / 4$;

38) M 6 - cpl. 34 / Str. Bisericii 98,2006 , la N de M 5 (cpl. 33), casetă practicată în malul E al şanţului pentru alimentarea cu apă de pe latura vestică a străzii - mormânt de inhumație; adâncime minimă $-0,74 \mathrm{~m}$ față de nivelul actual de călcare; orientare V-E; schelet bine păstrat, aşezat pe partea dreaptă; antebrațul drept pe lângă corp, antebrațul stâng deasupra bazinului; picioarele întinse, puțin deviate spre SE şi puțin flexate; L în groapă $-1,70 \mathrm{~m}$; fără inventar; încadrare cronologică: epoca romano-bizantină; caracteristici antropologice: prezintă craniu (glabelă şi mastoide grad +1 , diametru anteroposterior maxim $179,96 \mathrm{~mm}$ mijlociu, diametru transversal maxim 149,76 mm mijlociu, indice cranian orizontal 83,21 brahicran, oase wormiene pe traiectul suturii lambdoide stângi), mandibulă (unghiuri mandibulare grad -1 , menton grad 0), clavicule $(\operatorname{Lmax}=150,51 \mathrm{~mm} / 140,60 \mathrm{~mm}$, asimetrie), scapule, humerusuri ( $\operatorname{Lmax}=317,43$ $\mathrm{mm} / 321,17 \mathrm{~mm}$, faza I), radiusuri $(\mathrm{Lmax}=239,80$ $\mathrm{mm} / 239,43 \mathrm{~mm})$, ulnă stângă $(\operatorname{Lmax}=259,26$ mm), ulnă dreaptă (lipsă epifiză proximală), vertebre, coaste, sacrum, coxal stâng (ischion), coxal drept (şanț sciatic grad -1 , fațetă simfizară pubică faza I), femure (Lmax $=440,21 \mathrm{~mm} /$ $437,50 \mathrm{~mm}$, faza I), rotulă dreaptă, tibii $(\mathrm{Lmax}=$ $360,24 \mathrm{~mm} / 359,91 \mathrm{~mm})$, fibule $(\operatorname{Lmax}=347,52$ $\mathrm{mm} / 345,57 \mathrm{~mm}$ ), metacarpiene, metatarsiene şi falange; sex: masculin (oase lungi, de dimensiuni mari); vârstă: cca. 35,33 ani, maturus I (cu siguranță mai mică, cca. 22 ani, adultus, pe baza extremităților mediale claviculare proaspăt sudate la diafize şi capetelor de articulare în curs de sudare la corpurile vertebrale); talie: cca. 162,15 cm, submijlocie; fig. 4; 6/5;

39) M 7 - cpl. 35 / Str. Bisericii 98, 2006, la N de M 6 (cpl. 34), casetă practicată în malul E al şanţului pentru alimentarea cu apă de pe latura vestică a străzii - mormânt de inhumație; adâncime minimă $-1,17 \mathrm{~m}$ față de nivelul actual de călcare; orientare SV-NE; schelet în decubit ventral; antebrațul drept întins pe lângă corp, sub bazin, nu sunt vizibile oasele antebrațului stâng, probabil sub schelet; picioarele întinse; L în groapă - $1,57 \mathrm{~m}$; fără inventar; încadrare cronologică: epoca romano-bizantină; caracteristici antropologice: prezintă craniu (fragmentar, glabelă şi mastoide grad -1 , diametru antero-posterior maxim 182,10 mm lung, sutură metopică), mandibulă (unghiuri mandibulare şi menton grad 0), clavicule (Lmax $=144,67 \mathrm{~mm} /$ $146,22 \mathrm{~mm}$, subțiri, detalii anatomice ce se disting greu pe suprafața lor), scapule (fragmente ce cuprind cavitățile glenoide), humerus stâng (lipsă epifize), humerus drept ( $\operatorname{Lmax}=321,11 \mathrm{~mm}$, faza $\mathrm{V})$, radius stâng $(\operatorname{Lmax}=233,09 \mathrm{~mm}$ ), radius drept (un fragment ce cuprinde epifiza proximală), ulnă stângă (lipsă epifiză distală), vertebre, coaste, coxal stâng (fragmentar, şanț sciatic grad -1), femur stâng ( $\operatorname{Lmax}=431,76 \mathrm{~mm}$, linea aspera slab conturată), femur drept (cap femural) şi tibie dreaptă $(\operatorname{Lmax}=359,61 \mathrm{~mm})$; sex: feminin; vârstă: cca. 61 ani, senilis I; talie: cca 157,59 cm, supramijlocie; fig. 5; 6/6;

40) M 8 - cpl. 37 / Str. Bisericii 98, 2006, şanț pentru alimentarea cu apă de pe latura vestică a 
străzii; la 3,50 m N față de limita nordică a casetei pentru M 7 (cpl. 35) - mormânt de inhumaţie; adâncime minimă $-1,50 \mathrm{~m}$ față de nivelul actual de călcare; orientare V-E; schelet în decubit dorsal, din care sunt vizibile doar femurele care ies din malul $\mathrm{V}$ al şi parțial tibiile care pătrund în malul E; secționat de o groapă menajeră (cpl. 36); L surprinsă în şanț $0,55 \mathrm{~m}$; au fost recuperate doar oasele membrelor inferioare pentru eliberarea şanţului, renunţandu-se la caseta proiectată; fără inventar; încadrare cronologică: epoca romano-bizantină; caracteristici antropologice: prezintă femure $(\mathrm{Lmax}=486,95 \mathrm{~mm} /$ $484,39 \mathrm{~mm}$, faza II), rotulă dreaptă, tibie stângă (lipsă epifiză distală şi un fragment de treime proximală), tibie dreaptă $(\operatorname{Lmax}=383,42 \mathrm{~mm})$, fibulă stângă $(\operatorname{Lmax}=376,63 \mathrm{~mm})$, fibulă dreaptă (lipsă epifiză proximală), calcaneu stâng şi astragal stâng; sex: masculin (oase de dimensiuni mari, masive, groase, bogate în detalii anatomice, numeroase locuri de inserție musculară şi epifize mari); vârsta: cca. 44 ani, maturus II; talie: cca. $170,68 \mathrm{~cm}$, mare; fig. $6 / 7$;

41) M 9 - cpl. 40 / Str. Bisericii 98, 2006, la $\mathrm{S}$ faţă de limita nordică a gropii menajere (cpl. 36), şanț pentru alimentarea cu apă de pe latura vestică a străzii - mormânt de inhumație; casetă practicată în malul E al şanţului pentru alimentarea cu apă; adâncime minimă $-0,60 \mathrm{~m}$ față de nivelul actual de călcare; orientare V-E; schelet aşezat pe partea dreaptă, cu partea superioară afectată în zona cutiei toracice; humerusul stâng deplasat spre S; radiusul drept, deşi rupt, este întins pe lângă corp, antebrațul stâng fragmentar; femurul stâng uşor deplasat spre $\mathrm{S}$, peroneul stâng absent; secționat de o groapă menajeră (cpl. 39); L în groapă - 0,94 m; făă inventar; încadrare cronologică: epoca romanobizantină; caracteristici antropologice: prezintă craniu (fragmentar), mandibulă, scapule (corpuri fragmentare), humerusuri $(\operatorname{Lmax}=171,95$ $\mathrm{mm} / 172,50 \mathrm{~mm}$ ), radius drept (treime distală), ulnă stângă (jumătate proximală), vertebre, coaste, coxal stâng (ischion), femure ( $\operatorname{Lmax}=232,70$ $\mathrm{mm} / 231,93 \mathrm{~mm})$, tibie stângă $(\operatorname{Lmax}=184,35$ mm) şi metatarsiene; vârstă: cca. 6-7 ani, infans I (molarii 1 superiori şi inferiori proaspăt ieşiţi), cca. 4,5-5,5 ani, infans I (după lungimile maxime ale oaselor lungi); talie: cca. $122 \mathrm{~cm}$; fig. 5 ;

42) M 1/ Str. Bisericii 98, proprietatea A. Husein, 2005, casetă - mormânt de inhumație; adâncime minimă $-0,50 \mathrm{~m}$ față de nivelul actual de călcare; orientare V-E; schelet în decubit ventral, humerusul stâng deplasat spre $\mathrm{S}$; coastele dinspre nord au o dispunere anatomică normală, cele dinspre sud inversată; picioarele încrucişate, stângul deasupra dreptului; antebraţul drept sub claviculă, antebrațul stâng întins pe lângă corp, sub scapula dreaptă, L în groapă $-0,77 \mathrm{~m}$; fără inventar; groapa amenajată în pământ galben, a cărei formă nu este vizibilă; încadrare cronologică probabilă: epoca modernă; caracteristici antropologice: prezintă craniu (diametru anteroposterior maxim $162,14 \mathrm{~mm}$, diametru transversal maxim 128,48 mm, indice cranian orizontal 79,24 mezocran), mandibulă, claviculă dreaptă (Lmax = $77,96 \mathrm{~mm}$ ), scapulă dreaptă (întreagă), humerusuri $(\operatorname{Lmax}=131,53 \mathrm{~mm} / 130,89 \mathrm{~mm})$, radius drept $(\operatorname{Lmax}=99,24 \mathrm{~mm})$, ulne $(\operatorname{Lmax}=105,32$ $\mathrm{mm} / 105,64 \mathrm{~mm}$ ), vertebre, coaste, coxale (ilioane), femure $(\operatorname{Lmax}=172,11 \mathrm{~mm} / 171,40 \mathrm{~mm})$ şi tibie dreaptă $(\operatorname{Lmax}=135,89 \mathrm{~mm})$; vârstă: cca. 2 ani, infans I (premolarii 1 şi 2 inferiori deciduali ieşiţi, molarii 1 inferiori doar coroana, în alveolă), cca. 1,5-3,5 ani, infans I (după lungimile maxime ale oaselor lungi); talie: cca. 101,5 cm; fig. 18;

43) M 1/ Str. Bisericii 98, proprietatea A. Husein, 2007, S 1, c. 5 - mormânt de inhumație; adâncime minimă $-0,60$ sau $-0,70 \mathrm{~m}$ față de nivelul actual de călcare; orientare V-E; schelet din care se păstrează doar craniul; fără inventar; încadrare cronologică probabilă: epoca modernă; caracteristici antropologice: prezintă craniu (câteva fragmente de neurocraniu) şi hemimandibulă dreaptă; vârstă; cca. 1-2 ani, infans I (premolarul 1 inferior decidual ieşit, premolarul 2 inferior decidual proaspăt erupt);

44) $\mathrm{M} 2$ / Str. Bisericii 98, proprietatea $A$. Husein, 2007, S 1, c. 1, - 1,80, la N de M 2 mormânt de inhumație; adâncime minimă $-0,50 \mathrm{~m}$ față de nivelul actual de călcare; orientare SV-NE; schelet vizibil până la nivelul treimilor superioare tibiale, pătrunzând în malul E, bine conservat, în decubit dorsal, coastele deranjate pe partea dreaptă, radiusul drept deranjat, în poziție oblică, sub femurul drept, craniul aplecat pe partea dreaptă, antebraţul drept întins pe lângă corp, antebrațul stâng pe bazin; picioarele întinse, puțin deviate spre SE; L în groapă - 1,30 m; au fost recuperate tibiile; fără inventar; groapa amenajată în pământ galben, a cărei formă nu este vizibilă; încadrare cronologică: epoca romanobizantină; caracteristici antropologice: prezintă craniu (glabelă şi mastoide grad -1 , frunte joasă, 
rotunjită, eminențe frontale şi parietale mari, occipital cu linii nucale slab evidențiate, diametru antero-posterior maxim 175,18 $\mathrm{mm}$ mijlociu, diametru transversal maxim 129,31 $\mathrm{mm}$ foarte îngust, indice cranian orizontal 73,81 dolicocran), mandibulă (unghiuri mandibulare şi menton grad 1), clavicule $(\operatorname{Lmax}=132,99 \mathrm{~mm} / 133,08 \mathrm{~mm}$, epifizate de curând la nivelul extremităţilor mediale), scapule (întregi), humerusuri (Lmax $=283,49$ $\mathrm{mm} / 278,94 \mathrm{~mm}$, foramenuri olecraniene mari, faza I, asimetrie), radiusuri ( $\mathrm{Lmax}=221,57 \mathrm{~mm} / 223,29$ $\mathrm{mm})$, ulne $(\operatorname{Lmax}=239,14 \mathrm{~mm} / 241,38 \mathrm{~mm})$, vertebre, coaste, stern, coxale (pubisuri uşor afectate, golf pelvic eliptic, şanţuri sciatice grad -2 , foramen obturat triunghiular, jos, lat, cu margini ascuţite, unghi pubian de gradul -2), femure ( $\max =388,42$ $\mathrm{mm} / 387,50 \mathrm{~mm}$, faza I), tibii (Lmax $=322,26$ $\mathrm{mm} / 325,77 \mathrm{~mm})$, rotulă dreaptă, fibule (Lmax = $315,79 \mathrm{~mm} / 317,84 \mathrm{~mm}$ ), metacarpiene, metatarsiene şi falange; sex: feminin; vârstă: cca. 37 ani, maturus I (cu siguranță mai mică, deoarece claviculele sunt epifizate de curând la nivelul extremităților mediale); talie: cca. 148,69 cm, mică; fig. 5; 6/8; 30/4;

45) M $1 /$ Str. Bisericii, proprietatea D. Răileanu, 2006 - oase umane recuperate de la un mormânt de inhumaţie distrus la săparea mecanică a şanţului pentru alimentarea cu apă a gospodăriei; încadrare cronologică probabilă: epoca modernă; caracteristici antropologice: prezintă scapulă dreaptă (cavitate glenoidă şi coracoid), humerus drept (Lmax = 339,27 mm, lung, puternic, faza I), sacrum (îngust, lung, arcuit), coxal drept (masiv, locuri de inserție musculară proeminente, şanț sciatic grad +1 , fațetă simfizară pubică faza I) şi femur drept (treime distală); sex: masculin; vârstă: cca. 36,5 ani, maturus I; talie: cca. $167,42 \mathrm{~cm}$, supramijlocie;

46) $\mathrm{M} 2 /$ Str. Bisericii, proprietatea D. Răileanu, 2006 - oase umane recuperate de la un mormânt de inhumație distrus la săparea mecanică a şanţului pentru alimentarea cu apă a gospodăriei; încadrare cronologică probabilă: epoca modernă; caracteristici antropologice: prezintă mandibulă stângă (menton grad -2), claviculă stângă (lipsă extremitate medială), claviculă dreaptă (jumătate medială), scapulă stângă (fragmentară), humerus stâng (lipsă epifiză proximală), humerus drept (Lmax = 295,09 mm), radius stâng (lipsă treime distală), radius drept $(\operatorname{Lmax}=219,92 \mathrm{~mm})$, ulnă stângă (Lmax = 239,99 mm), ulnă dreaptă (treime distală spartă), vertebre, coaste, stern (manubriu), sacrum (S1), coxale (ilioane, gracile, locuri de inserție musculară puţin proeminente şi fragmente ce cuprind porţiunile acetabulare), femure (diafize şi epifize distale), tibie stângă (Lmax = 340,33 mm), tibie dreaptă (fragmente, fără conexiuni), fibule (lipsă epifize distale), metacarpiene, metatarsiene şi falange; sex: feminin; vârstă: cca. 20 ani, juvenis/adultus (epifiză proximală humerală dreaptă proaspăt fuzionată); talie: cca. 152,95 cm, submijlocie;

47) M 1 / Str. Bisericii 186, proprietatea N. Drăgan, 1980, S 1, c. 4, lângă malul S - mormânt de inhumație; adâncime minimă $-0,60 \mathrm{~m}$ față de nivelul actual de călcare; orientare V-E; schelet afectat de o construcție modernă, în decubit dorsal; craniul spart, antebraţul drept pe umăr, antebrațul stâng deplasat; L în groapă - 1,18 m; fără inventar; încadrare cronologică: epoca medio-bizantină (sec. XII-XIII); caracteristici antropologice: prezintă craniu (spart), mandibulă, scapulă dreaptă (aproximativ întreagă), humerusuri (Lmax = 190,63 mm/192,96 mm), radius stâng (Lmax $=139,74$ $\mathrm{mm}$ ), ulne (Lmax $=154,02 \mathrm{~mm} / 156,95 \mathrm{~mm})$, vertebre, coaste, stern (manubriu), sacrum (S1), coxale, femure $(\operatorname{Lmax}=257,79 \mathrm{~mm} / 257,33 \mathrm{~mm}$, faza I), tibii $(\operatorname{Lmax}=208,64 \mathrm{~mm} / 209,32 \mathrm{~mm})$, fibulă stângă $(\operatorname{Lmax}=205,21 \mathrm{~mm})$, metacarpiene, metatarsiene şi falange; vârstă: cca. 7-8 ani, infans II (premolarii 1 şi 2 superiori şi inferiori prezenţi, molarii 1 superiori şi inferiori ieşiţi, molarii 2 superiori şi inferiori doar coroanele, în alveole), cca. 5,5-7,5 ani, infans I/infans II, (după lungimile maxime ale oaselor lungi); talia: cca. $130,25 \mathrm{~cm}$; fig. $12 ; 13 / 3$;

48) M 2 / Str. Bisericii 186, proprietatea N. Drăgan, 1980, S 1, c. 3 - mormânt de inhumație; adâncime minimă $-0,90 \mathrm{~m}$ față de nivelul actual de călcare; orientare V-E; schelet în decubit dorsal; fără craniu, partea superioară a corpului distrusă de o construcție modernă; antebrațele distruse; L în groapă - 1,55 m; sicriu de lemn; inventar: o monedă de billon imitaţie latină de tip $\mathrm{D}$, din prima jumătate a sec. XIII, ICEM, inv. 40513; un cercel de tip verigă simplă, bronz, d = $15 \mathrm{~mm}$; ICEM, inv. 32207; încadrare cronologică: epoca mediobizantină (sec. XII-XIII); caracteristici antropologice: prezintă humerus drept (Lmax = $312,73 \mathrm{~mm}$, faza I), femure (Lmax $=419,56$ $\mathrm{mm} / 431,73 \mathrm{~mm}$, linea aspera slab dezvoltată, faza I, asimetrie), tibie dreaptă $(\mathrm{Lmax}=345,48 \mathrm{~mm})$, 
fibulă stângă (jumătate proximală), un metatarsian şi o falangă; sex: feminin (oase scurte, gracile, epifize mici); vârstă: cca. 37 ani, maturus I; talie cca. 154,81 cm, mijlocie; 48a); au mai fost identificate o diafiză humerală şi o diafiză femurală de pe partea dreaptă; categorie de vârstă: adultus/adult (de dimensiuni relativ mari); fig. 12; 13/4;

49) M 3 / Str. Bisericii 186, proprietatea N. Drăgan, 1980, S 1, c. 2-3, lângă malul S - mormânt de inhumație; adâncime minimă $-0,65 \mathrm{~m}$ față de nivelul actual de călcare; orientare V-E; a deranjat alte două morminte, din care au fost reînhumate doar craniile (unul de adult şi celălalt de copil), în stânga craniului M 3; schelet în decubit dorsal; craniul pe partea dreaptă, ambele antebrațe pe abdomen; L în groapă - 1,50 m; fără inventar; încadrare cronologică: epoca medio-bizantină (sec. XII-XIII); caracteristici antropologice: prezintă craniu (glabelă grad -1, diametru antero-posterior maxim 166,11 $\mathrm{mm}$, diametru transversal maxim 132,54 $\mathrm{mm}$ foarte îngust, indice cranian orizontal 79,79 mezocran), mandibulă (unghiuri mandibulare şi menton grad 1), clavicule $(\operatorname{Lmax}=136,22 \mathrm{~mm} / 133,41 \mathrm{~mm})$, scapule (întregi), humerusuri (Lmax $=285,17$ $\mathrm{mm} / 287,02 \mathrm{~mm}$, faza II), radiusuri (Lmax $=215,66$ mm/214,86 mm), ulnă stângă (Lmax = 234,42 mm), vertebre, coaste, stern, coxale (pelvis gracil, cu locuri de inserție musculară puțin proeminente, lat, jos, „golf” pelvic eliptic, şanţuri sciatice şi unghi pubian grad -2, fațetă simfizară pubică faza I), femure $(\mathrm{Lmax}=402,90 \mathrm{~mm} / 403,18 \mathrm{~mm}$, linea aspera $\mathrm{slab}$ evidențiată, faza I), tibie stângă (Lmax = 320,78 mm), fibulă stângă (Lmax = 317,91 mm), metacarpiene, metatarsiene şi falange; sex: feminin; vârstă: cca. 38,66 ani, maturus I; talie: cca. 149,64 cm, submijlocie; fig. 12; 13/5;

50) $\mathrm{M} 4$ / Str. Bisericii 186, proprietatea $N$. Drăgan, 1980, S 1, c. 2-3, lângă malul N mormânt de inhumație; adâncime minimă $-0,85 \mathrm{~m}$ față de nivelul actual de călcare; orientare V-E; groapa M 4 a distrus M 5 şi M 6, ale căror schelete au fost reînhumate, de o parte şi de alta, la picioarele M 4; schelet probabil de adult, posibil femeie, în decubit dorsal; ambele antebrațe pe bazin; L în groapă - 1,70 m; sicriu de lemn; fără inventar; încadrare cronologică: epoca mediobizantină (sec. XII-XIII); fig. 12; 13/6;

51) M 5 / Str. Bisericii 186, proprietatea $N$. Drăgan, 1980, S 1, c. 2 - mormânt de inhumație; orientare V-E; distrus de groapa $\mathrm{M} 4$, reînhumat la picioarele M 4; pe partea stângă a acestuia, schelet probabil de adult; L parțială în groapă - 0,75 m; fără inventar; încadrare cronologică: epoca bizantină (sec. XII-XIII); fig. 12;

52) M 6 / Str. Bisericii 186, proprietatea N. Drăgan, 1980, S 1, c. 2, lângă malul N - mormânt de inhumație; orientare $\mathrm{V}-\mathrm{E}$; distrus de groapa $\mathrm{M}$ 4, reînhumat la picioarele scheletului din M 4; pe partea dreaptă, schelet probabil de adult; L parțială în groapă - 0,60 m; fără inventar; încadrare cronologică: epoca medio-bizantină (sec. XIIXIII); fig. 12;

53) M 7 / Str. Bisericii 186, proprietatea $N$. Drăgan, 1980, S 1, c. 1, lângă malul E - mormânt de inhumație; adâncime minimă $-0,70 \mathrm{~m}$ față de nivelul actual de călcare; orientare V-E; schelet în decubit dorsal; craniul pe partea stângă, ambele antebrațe pe abdomen; L parțială în groapă - 0,70 m până la bazin; fără inventar; încadrare cronologică: epoca medio-bizantină (sec. XIIXIII); caracteristici antropologice: prezintă craniu (câteva fragmente), mandibulă, clavicule (Lmax = 120,63 mm/119,35 mm), scapule (lipsă fragmente de corp), humerus stâng (Lmax $=240,46$ mm), humerus drept (lipsă fragmente de epifiză proximală), radius drept $(\operatorname{Lmax}=185,98 \mathrm{~mm})$, ulnă stângă (treime proximală şi un fragment de diafiză), ulnă dreaptă (lipsă treime distală), stern, coxale (ilioane şi pubisuri), metacarpiene şi falange; vârstă: cca. 12 ani, infans II (după molarii 2 inferiori proaspăt ieşiți), cca. 9,5-11,5 ani, infans II (după lungimile maxime ale oaselor lungi); fig. 12; 13/7;

54) $\mathrm{M} 8$ / Str. Bisericii 186, proprietatea N. Drăgan, 1980, S 1, c. 1, lângă malul E - mormânt de inhumaţie; adâncime minimă $-0,60 \mathrm{~m}$ față de nivelul actual de călcare; orientare $\mathrm{V}-\mathrm{E}$; schelet în decubit dorsal; craniul pe partea stângă, antebrațul drept pe umăr, antebrațul stâng pe piept; L parțială în groapă - 0,40 m; pietre în zona craniului; fără inventar; încadrare cronologică: epoca mediobizantină (sec. XII-XIII); caracteristici antropologice: prezintă craniu (glabelă grad +2 , occipital foarte dezvoltat la nivelul inionului, prezentând creste ce denotă locuri de inserție a unei musculaturi puternice, diametru antero-posterior maxim 193,91 mm lung, diametru transversal maxim 131,75 $\mathrm{mm}$ foarte îngust, indice cranian orizontal 67,94 hiperdolicocran), mandibulă 
(unghiuri mandibulare grad +1 , menton grad +2 ), clavicule $(\operatorname{Lmax}=155,02 \mathrm{~mm} / 149,06 \mathrm{~mm}$, asimetrie), scapule (lipsă fragmente de la nivelul corpului), humerusuri ( $\operatorname{Lmax}=353,79 \mathrm{~mm} / 342,77$ $\mathrm{mm}$, asimetrie, faza III), radius drept (Lmax = 258,08 mm), ulnă dreaptă (Lmax = 280,98 mm), vertebre, coaste, stern, metacarpiene şi falange; sex: masculin; vârstă: cca. 57 ani, senilis I; talie: cca. $169,85 \mathrm{~cm}$, supramijlocie; 54a) au mai fost identificate un craniu (fragmentar), mandibulă, scapulă stângă, humerus drept (Lmax $=120,16$ $\mathrm{mm})$, radius drept $(\mathrm{Lmax}=89,64 \mathrm{~mm})$, ulnă dreaptă $(\operatorname{Lmax}=97,11 \mathrm{~mm})$, coaste (câteva) şi vertebre; vârstă: cca. 2 ani, infans I (unul din incisivi ieşit, molarul 1 stânga în alveolă, doar coroana), cca. 0,5-2,5 ani, infans I (după lungimile maxime ale oaselor lungi); fig. 12; 13/7;

55) $\mathrm{M} 9$ / Str. Bisericii 186, proprietatea N. Drăgan, 1980, S 1, c. 1, lângă malul S - mormânt de inhumație; orientare V-E; schelet probabil de adult, în decubit dorsal; câteva oase îngrămădite în stânga bazinului; L parțială în groapă - 0,40 m; fără inventar; încadrare cronologică: epoca mediobizantină (sec. XII-XIII); fig. 12;

56) M 10 / Str. Bisericii 186, proprietatea N. Drăgan, 1980, S 1, c. 3, lângă malul N - mormânt de inhumație; adâncime minimă $-0,80 \mathrm{~m}$, față de nivelul actual de călcare; orientare V-E; deranjat de M 11, care a fost înhumat deasupra; schelet în decubit dorsal; craniul căzut pe partea stângă, ambele antebrațe pe umăr; L în groapă - 1,60 sau $1,80 \mathrm{~m}$; sicriu de lemn; pietre în zona craniului; fără inventar; suprapus de M 11; încadrare cronologică: epoca medio-bizantină (sec. XIIXIII); caracteristici antropologice: prezintă craniu (fragmentar), hemimandibulă dreaptă, clavicule $($ Lmax $=157,14 \mathrm{~mm} / 154,21 \mathrm{~mm})$, scapule (aproximativ întregi), humerus drept (Lmax = 332,66, faza III), radius stâng (lipsă epifiză distală), radius drept $(\mathrm{Lmax}=260,71 \mathrm{~mm})$, vertebre (două), coaste (câteva), stern, sacrum (îngust, lung, arcuit), coxale (şanţuri sciatice grad +1 , unghi pubian grad +2 , ilion ce tinde spre vertical, fațetă simfizară pubică faza II), femure (Lmax $=453,09 \mathrm{~mm} / 455,23$ mm, faza II), tibie stângă (lipsă epifiză distală), tibie dreaptă (Lmax = 374,07 mm), fibulă stângă (diafiză fibulară), fibulă dreaptă $(\operatorname{Lmax}=360,42)$, metacarpiene şi metatarsiene; sex: masculin; vârstă: cca. 46,33 ani, maturus II; talie: cca. 165,62 cm, mijlocie; elemente de patologie: carie la nivelul molarului 2 superior dreapta; fig. 12; 30/5;
57) M 11 / Str. Bisericii 186, proprietatea N. Drăgan, 1980, S 1, c. 3, lângă malul N - mormânt de inhumaţie; adâncime minimă $-0,75 \mathrm{~m}$ față de nivelul actual de călcare; orientare V-E; depus, din zona pieptului M 10 în jos, peste acesta, peste sicriul lui de fapt; schelet în decubit dorsal; craniul mult deplasat, cu privirea spre $\mathrm{N}$, ambele antebrațe pe bazin; L în groapă - 1,40 sau 1,50 m; inventar: o monedă bizantină schifată emisă la Constantinopol de Isaac II Comnenul 1185-1195 în zona bazinului, tip A, Isaac II, ICEM, inv. 40509; încadrare cronologică: epoca medio-bizantină (sec. XIIXIII); caracteristici antropologice: prezintă craniu (fragmentar), hemimandibulă dreaptă, scapule (aproximativ întregi), humerus drept (Lmax = $322,52 \mathrm{~mm}$, faza III), ulne (Lmax $=266,04$ $\mathrm{mm} / 265,55 \mathrm{~mm}$ ), stern (manubriu), sacrum (îngust, lung, arcuit), coxal drept (ilion ce tinde spre vertical, şanț sciatic grad +1 , fațetă simfizară pubică faza III), femur drept (epifiză distală), tibie dreaptă $(\operatorname{Lmax}=350,35 \mathrm{~mm})$, fibulă dreaptă $(\operatorname{Lmax}=343,25 \mathrm{~mm})$; sex: masculin; vârstă: cca. 54,5 ani, senilis I; talie: cca. $161,99 \mathrm{~cm}$, submijlocie; elemente de patologie: edentație la nivelul molarilor inferiori, discontinuităţi osoase datorate unor fracturi (vindecate) la nivelul jumătății diafizare radiale şi ulnare drepte, exostoză la nivelul crestei tibiale drepte; fig. 12; 13/8; 30/6;

58) $\mathrm{M} 10$ / cpl. 43 / Str. Bisericii 97, 2006, şanț pentru alimentarea cu apă de pe latura vestică a străzii; la $6,85 \mathrm{~m} \mathrm{~N}$ față de limita nordică a porții mari a casei cu nr. 97 - mormânt de inhumație; nu s-a practicat casetă; adâncime minimă $-0,90$ m față de nivelul actual de călcare; orientare $\mathrm{V}-\mathrm{E}$; schelet în decubit dorsal; femurele ies din malul $\mathrm{V}$ al şanţului, tibiile şi peroneele dislocate în momentul săpării mecanice a şanţului; partea superioară a scheletului nerecuperată, pătrunde în malul V; fără inventar în porțiunea cercetată; încadrare cronologică probabilă: epoca modernă; caracteristici antropologice: prezintă femur stâng (jumătate distală), femur drept (Lmax $=446,59 \mathrm{~mm}$, faza I), tibie stângă (Lmax = 375,37 mm), fibulă stângă $(\operatorname{Lmax}=362,97 \mathrm{~mm})$ şi fibulă dreaptă (lipsă epifiză distală); sex: masculin (oase lungi, masive, groase, multe locuri de inserție musculară, epifize mari); vârstă: cca. 33 ani, maturus I; talie: cca. 164,88 cm, mijlocie; elemente de patologie: exostoze la nivelul epifizei proximale fibulare stângi; 
59) M 11 / cpl. 44 / Str. Bisericii 97, 2006, şanţ pentru alimentarea cu apă de pe latura vestică a străzii; la 10 m N față de limita nordică a porții mari a casei cu nr. 97, la 2,90 m distanță spre N față de M10 (cpl. 43) - mormânt de inhumație; nu s-a practicat casetă; adâncime minimă $-0,90$ m față de nivelul actual de călcare; orientare V-E; schelet în decubit dorsal; părţi ale antebrațelor şi coloanei, coxalele şi oasele membrelor inferioare au fost recuperate după săparea mecanică a şanțului V pentru alimentare cu apă; partea superioară a scheletului pătrunde în malul V; fără inventar în porțiunea cercetată; încadrare cronologică probabilă: epoca modernă; caracteristici antropologice: resturi osteologice ce provin de la doi indivizi: 1) prezintă radius drept (lipsă treime distală), ulnă stângă (lipsă epifiză proximală), vertebre, o coastă, sacrum (larg, scurt, puțin arcuit), coxal drept (lipsă pubis, şanț sciatic grad 2), femure (Lmax $=430,15 \mathrm{~mm} / 430,82 \mathrm{~mm}$, gracile, faza II), tibie stângă (Lmax $=342,98$ mm), tibie dreaptă (lipsă fragmente de diafiză), fibulă (un fragment de diafiză) şi falange; sex: feminin; vârstă: cca. 44 ani, maturus II; talie: cca. 155,29 cm, mijlocie; 2) prezintă femur stâng (lipsă epifiză proximală), femur drept (spart) şi tibie dreaptă (lipsă epifiză distală); vârstă: maxim 13 ani, infans II (epifize nefuzionate; prin comparație dimensională cu alte oase aparținând grupei infans II);

60) M 12 - cpl. 45 / Str. Bisericii 97, 2006, şanț pentru alimentarea cu apă de pe latura vestică a străzii; la 1,10 m N față de M 11 (cpl. 44) mormânt de inhumație; nu s-a practicat casetă; adâncime minimă $-0,50 \mathrm{~m}$ față de nivelul actual de călcare; orientare V-E; schelet în decubit dorsal; vizibile tibiile şi peroneele, care pătrund în malul E al şanțului pentru alimentare cu apă; au fost recuperate membrele inferioare; fără inventar în porțiunea cercetată; încadrare cronologică probabilă: epoca modernă; caracteristici antropologice: prezintă o vertebră lombară, o coastă, femur stâng (lipsă epifiză proximală, gros, de dimensiuni mari), femur drept (diafiză femurală), tibie stângă (jumătate proximală) şi tibie dreaptă (diafiză tibială); sex: masculin; vârstă: peste 19 ani, juvenis/adult (epifize fuzionate);

61) M 13 - cpl. 47 / Str. Bisericii 97, 2006, şanț pentru alimentarea cu apă de pe latura vestică a străzii; la 2,10 m distanţă spre N față de limita nordică a stâlpului din dreptul casei - mormânt de inhumaţie; nu s-a practicat casetă; adâncime minimă $-0,45$ m față de nivelul actual de călcare; orientare V-E; schelet probabil de adult, în decubit dorsal, din care craniul s-a distrus probabil, fără a putea fi recuperat, la săparea mecanică a şanţului, fiind vizibile pe malul $\mathrm{E}$ al şanţului pentru alimentare cu apă coastele şi partea superioară a humerus-urilor, pe o lăţime de $0,40 \mathrm{~m}$, scheletul pătrunzând în malul E; nu au fost recuperate părți din schelet; documentat doar prin înregistrarea cpl. pe profil; fără inventar în porțiunea cercetată; încadrare cronologică probabilă: epoca modernă;

62) M / Str. Bisericii 96, 2006, şanţ pentru alimentarea cu apă de pe latura vestică a străzii oase umane recuperate din zona menajeră reprezentată de cpl. 49 a; nu a putut fi identificată groapa mormântului; încadrare cronologică probabilă: epoca romano-bizantină (ante sec. XI după fragmentele ceramice); caracteristici antropologice: prezintă scapulă dreaptă (acromion şi corp), humerus drept (lipsă treime distală), o coastă, coxal stâng (ilion, de dimensiuni reduse, sanț sciatic grad -1), femur drept (lipsă treime proximală, linea aspera slab dezvoltată), tibie stângă (diafiză tibială) şi fibulă stângă (lipsă epifiză distală); sex: feminin; vârstă: cca. 51 ani, senilis I;

63) M 14 - cpl. 53 / Str. Bisericii 95, 2006, şanţ pentru alimentarea cu apă de pe latura vestică a străzii; în dreptul şanţului mic, pentru alimentarea cu apă a gospodăriei casei cu nr. 95, în dreptul porții mici a casei, casetă în malul E al şanţului pentru alimentare cu apă - mormânt de inhumație; adâncime minimă $-0,55 \mathrm{~m}$ față de nivelul actual de călcare; orientare V-E; mormânt deranjat?/reînhumare?, conţinând elemente de schelet aparținând mai multor individizi; L în groapă - 0,76 m; fără inventar în porțiunea cercetată; încadrare cronologică probabilă: epoca modernă; caracteristici antropologice: resturi osteologice ce provin de la trei indivizi: 1) prezintă craniu (lipsă fragmente de frontal, oase wormiene în zona intersecției suturilor sagitală şi lambdoidă), mandibulă (unghiuri mandibulare grad -1), claviculă dreaptă (jumătate laterală), humerus stâng (Lmax = 291,16 mm, scurt, gracil, faza II), radius stâng (treime proximală), ulnă stângă (treime proximală), vertebre, femur stâng (lipsă epifiză proximală) şi fibule (diafize); sex: feminin; vârstă: cca. 51 ani, senilis I; talie: cca. 
$150,35 \mathrm{~cm}$, submijlocie; 2) prezintă claviculă stângă (Lmax $=171,39 \mathrm{~mm}$, groasă, mare), radius stâng (jumătate proximală, groasă), femure (diafize, puternice, groase) şi tibie dreaptă (diafiză); sex: masculin; vârstă: peste 19 ani, adultus/adult (epifize fuzionate); pe lângă aceste oase, au mai fost identificate vertebre, coaste, stern (manubriu), metacarpiene, metatarsiene şi falange, pe care nu le-am putut atribui cu exactitate unuia dintre cei doi indivizi; 63a) au mai fost identificat un femur drept (lipsă epifiză distală) şi o tibie stângă (diafiză); categorie de vârstă: infans I (prin comparație dimensională cu alte oase aparținând grupei infans I); fig. 18; 22/2;

64) M 15 - cpl. 54 / Str. Bisericii 95, 2006, şanț pentru alimentarea cu apă de pe latura vestică a străzii; în dreptul şanțului mic, pentru alimentarea cu apă a gospodăriei casei cu nr. 95 , la 3 m N față de M 14 (cpl. 53) - mormânt de inhumație; casetă practicată în malul V al şanțului pentru alimentarea cu apă; adâncime minimă $-0,58$ $\mathrm{m}$ față de nivelul actual de călcare; orientare V-E; schelet în decubit dorsal, relativ bine păstrat; partea dreaptă pare deranjată (vertebrele din partea inferioară deranjate, femurul drept absent); vizibil doar până în dreptul zonei în care ar fi trebuit să se afle rotulele, tibiile pătrunzând în malul E; humerusurile dispuse pe lângă corp, oasele antebraţelor deranjate, probabil afectate de şanțul vechi pentru alimentarea cu apă a gospodăriei; craniul pe partea stângă; L în groapă - 1,32 m; amprente de lemn de la sicriu sub humerus-ul stâng şi sub jumătatea dreaptă a scheletului; fără inventar; încadrare cronologică: epoca modernă; caracteristici antropologice: oseminte ce aparțin la trei indivizi: 1) prezintă craniu (glabelă şi mastoide grad +1 , relief nucal puternic dezvoltat, inion de forma unei creste, diametru antero-posterior maxim $178,42 \mathrm{~mm}$ mijlociu, diametru transversal maxim $143,28 \mathrm{~mm}$ îngust, indice cranian orizontal 80,28 brahicran), mandibulă (unghiuri mandibulare şi menton grad +1$)$, claviculă stângă (Lmax = $160,42 \mathrm{~mm}$, groasă, mare, locuri de inserție musculară evidente), scapule (puternice, lungi, margini vertebrale groase), humerusuri (Lmax $=$ $372,83 \mathrm{~mm} / 370,99 \mathrm{~mm}$, faza IV), ulnă dreaptă (diafiză), ulnă stângă (jumătate distală), vertebre, stern (corp), sacrum (aproximativ întreg, îngust, lung, uşor arcuit), coxale (fațete simfizare pubice faza III), femur stâng ( $\operatorname{Lmax}=526,18 \mathrm{~mm}$, faza III), metacarpiene, metatarsiene şi falange; sex: masculin; vârstă: cca. 54,33 ani, senilis I; talie: cca. 177,55 cm, mare; elemente de patologie: exostoze la nivelul vertebrelor, edentații în spațiul dintre premolarul 2 şi molari inferiori stânga şi la nivelul molarilor inferiori dreapta; 64a) elemente ale unui schelet ce prezintă: femur drept (treime proximală, faza III), tibie stângă (jumătate distală), tibie dreaptă $(\operatorname{Lmax}=357,78 \mathrm{~mm})$, fibulă (diafiză) şi astragale; sex: feminin (oase gracile, epifize de dimensiuni mici); vârstă: cca. 52 ani, senilis I; talie: cca. $157,65 \mathrm{~cm}$, supramijlocie; 64b) a mai fost identificat un femur stâng (Lmax = 175,24 mm); vârstă: cca. 1,5-3,5 ani, infans I (pe baza lungimii maxime); talie: cca. 103,5 cm; fig. 18; 22/4;

65) M 4 / Str. Bisericii 94, în dreptul casei familiei Dobrin, 1999, doar recuperat scheletul, contextul arheologic parțial distrus - mormânt de inhumație în decubit dorsal; orientare V-E; scheletul păstrat până la bazin inclusiv, antebrațul drept pe bazin; inventar recuperat reprezentat de mărgele de sticlă; încadrare cronologică: epoca medio-bizantină; caracteristici antropologice: prezintă craniu (aproximativ complet, fragmentar), mandibulă, claviculă stângă (Lmax = 99,66 mm), scapule (întregi), humerusuri (Lmax = 212,37 mm/211,60 mm), radius stâng (lipsă fragmente de diafiză), ulnă dreaptă (Lmax = $174,55 \mathrm{~mm}$ ), vertebre, coaste, stern (manubriu), sacrum (fragmentar), coxale (ilioane); vârstă: cca. 9-11 ani, infans II (molarii 2 inferiori în curs de ieşire), cca. 6,5-8,5 ani, infans I/infans II (după lungimile maxime ale oaselor lungi); elemente de patologie: carie la nivelul premolarului 2 inferior stânga;

66) M 1/ Str. Bisericii 94, la 6 m distanţă est de Căminul cultural şi la 4,5 m distanță față de colțul sud-estic al aceleiaşi clădiri, 1999, mai la N față de M 4 / 1999 - mormânt de inhumație, cu circa $0,10 \mathrm{~m}$ mai jos față de actualul nivel de călcare al străzii; orientare $\mathrm{V}-\mathrm{E}$; schelet în decubit dorsal, parţial conservat (lipseşte partea inferioară a scheletului, inclusiv bazinul, secționată probabil la trasarea străzii; L scheletului în groapă $=0,48 \mathrm{~m}$; craniul culcat pe un pat de fragmente ceramice şi cărămizi, antebraţul drept sprijinit pe bazin, antebrațul stâng întins pe lângă corp; fără inventar; încadrare cronologică: epoca modernă; caracteristici antropologice: prezintă craniu (un fragment), claviculă (un fragment de diafiză), scapulă dreaptă 
(fragmente), humerus stâng (jumătate distală), humerus drept (Lmax $=309,59 \mathrm{~mm}$, gros, bogat în detalii anatomice, faza I), radius stâng (jumătate proximală), radius drept $(\operatorname{Lmax}=231,66 \mathrm{~mm})$, ulnă stângă (jumătate proximală), ulnă dreaptă (treime proximală), vertebre, coaste, coxal (un fragment de pubis), metacarpiene, metatarsiene şi falange; sex: probabil masculin (oase puternice, groase, multe locuri de inserție musculară, epifize mari); vârstă: cca. 41 ani, maturus II; talie: cca. $159,13 \mathrm{~cm}$, mică;

67) M 16 - cpl. 55 / Str. Bisericii 94, 2006, şanț pentru alimentarea cu apă de pe latura vestică a străzii; la N de stâlpul din dreptul proprietății mormânt de inhumație; adâncime minimă $-0,50 \mathrm{~m}$ față de nivelul actual de călcare; orientare probabil V-E; schelet probabil de adult, deranjat/reînhumare?; vizibile oasele rupte ale membrelor pe malul V; nu au fost recuperate părți din schelet; inventar recuperat: două brățări de sticlă; încadrare cronologică probabilă: epoca medio-bizantină (sec. XI-XII);

68) M 17 - cpl. 57 / Str. Bisericii 94, 2006, casetă practicată în malul E al şanţului pentru alimentarea cu apă de pe latura vestică a străzii mormânt de inhumație; reperat craniul pe malul E al şanţului; adâncime minimă $-0,60 \mathrm{~m}$ față de nivelul actual de călcare; orientare V-E - $344^{\circ}$ $\mathrm{NNV}, 167^{\circ} \mathrm{SSE}$; schelet în decubit dorsal; posibil deranjat de o rădăcină care străbate groapa mormântului; craniul afectat de presiunea pământului, fără maxilar; humerus-ul drept mult depărtat de corp, cu antebraţul drept pe abdomen, radiusul stâng deplasat, humerusul şi ulna stângi lipsesc, posibil deranjate de rădăcină; L parțială în groapă - 1,02 m; amprente de lemn de la sicriu sub partea stângă a coloanei vertebrale; suprapus de groapa menajeră reprezentând cpl. 56; inventar: o monedă fragmentară de argint otomană sub palma dreaptă; încadrare cronologică: epoca modernă; caracteristici antropologice: prezintă craniu (fragmentar), mandibulă, claviculă dreaptă (Lmax $=85,92 \mathrm{~mm})$, scapulă stângă, scapulă dreaptă (lipsă mici porțiuni de la nivelul corpului), humerus drept (Lmax $=161,69 \mathrm{~mm})$, radius stâng $(\operatorname{Lmax}=117,62 \mathrm{~mm})$, ulnă dreaptă $(\operatorname{Lmax}=$ 133,34 mm), vertebre, coaste, coxale (ilioane, pubisuri), femur stâng (lipsă treime distală), femur drept $($ Lmax $=215,62 \mathrm{~mm})$, tibie stângă (Lmax = $167,46 \mathrm{~mm}$ ), tibie dreaptă (jumătate distală distrusă), fibulă stângă (Lmax $=162,24 \mathrm{~mm})$, fibulă dreaptă (lipsă epifiză distală), metatarsiene şi falange; vârstă: cca. 4-6 ani, infans I (după stadiul de erupție al molarilor 1 inferiori), cca. 2,5-5,5 ani, infans I (după lungimile maxime ale oaselor lungi); talie: cca. 115 cm; fig. 18; 22/3;

69) $M$ / Str. Bisericii 94, 2006, şanţ pentru alimentarea cu apă a satului, pe latura vestică a străzii - oase umane recuperate din groapa menajeră reprezentată de cpl. 61; probabil complex funerar afectat de săparea gropii; încadrare cronologică probabilă: epoca romanobizantină (ante sec. XI); caracteristici antropologice: prezintă humerus stâng (Lmax = 279,96 mm, subțire, suprafață netedă, faza II), sacrum (distrus, puțin arcuit), coxal drept (ischion, şanț sciatic grad -1), femure (epifize proximale sparte), tibie dreaptă (Lmax = 367,62 mm), fibulă stângă (jumătate proximală) şi fibulă dreaptă (Lmax = 326,83 mm); sex: feminin; vârstă: cca. 51 ani, senilis I; talie: cca. 147,27 cm, mică;

70) M 1 / Str. Bisericii 94, proprietatea C. Dobrin, 2001 - schelet uman recuperat, fără context arheologic; inventar recuperat: monede otomane de argint; încadrare cronologică: epoca modernă; caracteristici antropologice: prezintă craniu (fragmentar, glabelă grad +1 , eminențe frontale şi parietale mici, occipital foarte bine dezvoltat în regiunea inionului, linii nucale bine evidențiate), mandibulă (unghiuri mandibulare şi menton grad +1 ), scapule (întregi), humerusuri $($ Lmax $=350,07 \mathrm{~mm} / 355,90 \mathrm{~mm}$, faza I, asimetrie), radius stâng (lipsă treime proximală), radius drept $(\operatorname{Lmax}=270,08 \mathrm{~mm})$, ulnă stângă (diafiză ulnară), ulnă dreaptă $(\operatorname{Lmax}=286,20$ $\mathrm{mm}$ ), câteva vertebre şi coaste, coxal drept (şanţ sciatic grad +1 , acetabulum larg, având tendința de a fi direcționat în lateral) şi femur stâng (lipsă epifiză distală, linea aspera bine dezvoltată); sex: masculin; vârstă: cca. 41 ani, maturus II; talie: cca. 171,26 cm, mare;

71) M 2 / Str. Bisericii 94, proprietatea C. Dobrin, 2001, la sud de M 1 - schelet uman recuperat, fără context arheologic; încadrare cronologică: epoca modernă; caracteristici antropologice: prezintă craniu (fragmentar, relief şters, glabellă grad -1, eminențe frontale şi parietale dezvoltate), claviculă dreaptă (jumătate laterală, subțire, gracilă), scapulă stângă (fragmentară), humerusuri (lipsă epifize proximale), radius stâng (diafiză radială), ulnă 
dreaptă (lipsă epifiză distală), vertebre, coaste, stern, coxal drept (ilion, ischion cu cavitatea acetabulară, şanț sciatic grad -1) şi diafize femurale; sex: feminin; vârstă: peste 15 ani, juvenis/adult (epifize fuzionate);

72) - 73) M / Str. Bisericii 94, 2002, proprietatea C. Dobrin - 2 cranii umane recuperate, fără context arheologic; încadrare cronologică: epoca modernă; caracteristici antropologice: resturi osteologice ce provin de la doi indivizi: 1) prezintă craniu (glabelă şi mastoide $\operatorname{grad}+1$, arcuri supraciliare proeminente, frunte înaltă, retrasă, occipital cu linii nucale bine evidenţiate, diametru antero-posterior maxim 181,92 mm mijlociu, diametru transversal maxim 130,66 mm foarte îngust, indice cranian orizontal 71,82 dolicocran); sex: masculin; categorie de vârstă: adult (grad ridicat de obliterare a suturilor craniene); 2) prezintă craniu (glabelă şi mastoide grad -1 , arcuri supraciliare puțin proeminente, plane, frunte joasă, rotunjită, occipital cu linii nucale slab evidenţiate, diametru antero-posterior maxim 167,18 $\mathrm{mm}$ scurt, diametru transversal maxim 131,19 $\mathrm{mm}$ foarte îngust, indice cranian orizontal 78,47 mezocran); sex: feminin; categorie de vârstă: adult (grad ridicat de obliterare a suturilor craniene);

\section{STR. BISERICII, ZONA CĂMINULUI} CULTURAL

74) M $1 /$ Str. Bisericii, curtea Căminului cultural, 1980, S 1, c. 5 - mormânt de inhumaţie; orientare V-E; schelet probabil de adult, în decubit dorsal; ambele antebrațe pe abdomen, lipsesc tibia şi peroneul drepte, probabil deranjate de înhumarea M 2; L în groapă - 1,50 m; inventar: monedă, secolele XVII-XVIII, perforată lateral, ruptă ?, 0,24 g, 11,50x10,73 mm, ICEM, inv. 42352; încadrare cronologică: epoca modernă; fig. 19/3-4;

75) M 2 / Str. Bisericii, curtea Căminului cultural, 1980, S 1, c. 4 - mormânt de inhumaţie; la $\mathrm{E}$ de $\mathrm{M}$ 1, îl suprapune puțin în partea inferioară, craniul, deranjând piciorul drept; orientare NV-SE; schelet probabil de adult, în decubit dorsal; antebraţul drept pătrunde în mal, antebrațul stâng pe abdomen; L în groapă - 1,35 m; inventar: monedă, Mahmud II Constantinopol, anul 2, 1809/10, perforată, 0,21 g, 14,86 mm, ICEM, inv. 42353, ac de păr, bronz, gr. $0,5 \mathrm{~mm}$, tija lungă de $47 \mathrm{~mm}$, ruptă, puncte pe spate prin ciocănire, inv. ICEM 32208; încadrare cronologică: epoca modernă; fig. 19/3, 5;

76) M 3 / Str. Bisericii, curtea Căminului cultural, 1980, S 1, c. 3 - mormânt de inhumație; la E de gruparea M 1-2; orientare V-E; schelet probabil de adult, în decubit dorsal; fără craniu, antebraţul drept pe abdomen, antebrațul stâng pe bazin; L parțială în groapă - 1,70 m; fără inventar; încadrare cronologică: epoca modernă; fig. 19/6;

77) M 4 / Str. Bisericii, curtea Căminului cultural, 1980, S 1, c. 2 - mormânt de inhumație; orientare V-E; schelet în decubit dorsal; Lgropii =1,80 m; fără inventar; încadrare cronologică: epoca modernă; caracteristici antropologice: prezintă craniu (fragmentar), mandibulă, scapule (întregi), humerus stâng (Lmax $=161,66 \mathrm{~mm}$ ), humerus drept (lipsă epifiză proximală), radius drept $(\operatorname{Lmax}=114,33 \mathrm{~mm})$, ulne $(\operatorname{Lmax}=126,77$ $\mathrm{mm} / 126,86 \mathrm{~mm}$ ), vertebre, coaste, coxale (ilioane, ischioane, fragmentare), femure (Lmax $=212,21$ mm/216,42 mm), tibie dreaptă (lipsă epifiză distală), fibule $(\operatorname{Lmax}=170,30 \mathrm{~mm} / 171,23 \mathrm{~mm})$, metacarpiene, metatarsiene şi falange; vârstă: cca. 5-6 ani infans I (molarii 1 inferiori în curs de ieşire), cca. 2,5-5,5 ani, infans I (după lungimile maxime ale oaselor lungi); talie: cca. $116 \mathrm{~cm}$; au mai fost identificate un fragment de craniu (calotă craniană) şi o claviculă dreaptă $(\operatorname{Lmax}=126,84$ mm, scurtă, gracilă, slab arcuită, detalii anatomice ce se disting cu greu pe suprafaţa sa); sex: feminin; vârstă: cca. 17-21 ani, juvenis/adultus (extremitate medială claviculară dreaptă nefuzionată);

78) M 5 / Str. Bisericii, curtea Căminului cultural, 1980, S 2, c. 4 - mormânt de inhumație; orientare $\mathrm{V}-\mathrm{E}$; schelet în decubit dorsal; craniul pe partea stângă, ambele antebrațe pe abdomen, chiar deasupra bazinului; inventar: monedă Mahmud II, 0,07 g, 11,51 × 11,84 mm, ICEM, inv. 41421; fals după o monedă din a doua jumătate a secolului XVIII - începutul sec. XIX, 0,15 g, 11,71 mm, neperforată, ICEM, inv. 42354; Mahmud II, para, anul 17, 1824/25, neperforată, 0,10 g, 13,70 mm, ICEM, inv. 42354; colier, mărgele sticlă, ICEM, inv. 26151-26572; butoni, sticlă, ICEM, inv. 26148-26149; încadrare cronologică: epoca modernă; caracteristici antropologice: prezintă craniu (fragmentar), clavicule $(\operatorname{Lmax}=91,86 \mathrm{~mm} / 89,83 \mathrm{~mm})$, scapule 
(întregi), humerusuri (Lmax $=193,19 \mathrm{~mm} / 192,95$ $\mathrm{mm})$, radius stâng $(\operatorname{Lmax}=133,86 \mathrm{~mm})$, radius drept (lipsă epifiză distală), ulnă stângă (Lmax = 144,88 mm), ulnă dreaptă (lipsă epifiză distală), vertebre, coaste, sacrum, coxale (ilioane, ischion drept), femure $(\operatorname{Lmax}=258,72 \mathrm{~mm} / 258,98 \mathrm{~mm})$, tibii $(\operatorname{Lmax}=202,19 \mathrm{~mm} / 203,41 \mathrm{~mm})$, fibule $(\operatorname{Lmax}=200,31 \mathrm{~mm} / 200,13 \mathrm{~mm})$, metacarpiene, metatarsiene şi falange; vârstă: cca. 7-8 ani, infans II (incisivul 2 superior stânga în curs de ieşire, premolarii 1 şi 2 superiori şi inferiori încă în alveole, molarii 1 superiori şi inferiori ieşiţi), cca. 4,5-7,5 ani, infans I/infans II (după lungimile maxime ale oaselor lungi); fig. 19/7;

79) M 6 / Str. Bisericii, curtea Căminului cultural, 1980, S 2 - mormânt de inhumație; orientare $\mathrm{V}-\mathrm{E}$; schelet în decubit dorsal; fără craniu, ambele antebrațe pe bazin; fără inventar; încadrare cronologică: epoca modernă; caracteristici antropologice: prezintă scapulă stângă, humerus stâng (lipsă epifiză proximală), radiusuri $(\operatorname{Lmax}=242,28 \mathrm{~mm} / 243,95 \mathrm{~mm})$, ulnă stângă (lipsă epifiză proximală), ulnă dreaptă $(\operatorname{Lmax}=264,41 \mathrm{~mm})$, câteva vertebre, coaste, sacrum (fragmentar), coxal stâng (masiv, locuri de inserție musculară proeminente, foramen obturat oval, ax vertical lung, fațetă simfizară pubică faza I), femure $(\operatorname{Lmax}=433,93 \mathrm{~mm} / 434,03 \mathrm{~mm}$, faza I), tibii $(\operatorname{Lmax}=358,36 \mathrm{~mm} / 357,36 \mathrm{~mm})$, fibule $(\operatorname{Lmax}=358,52 \mathrm{~mm} / 358,56 \mathrm{~mm})$ şi calcanee; sex: masculin; vârstă: cca. 32,5 ani, maturus I; talie: cca. 162,04 cm, submijlocie; fig. 19/8;

80) M 1 - cpl. 63 / Str. Bisericii, zona Căminului cultural, 2006, casetă practicată în malul E al şanţului pentru alimentarea cu apă de pe latura vestică a străzii - mormânt de inhumație; adâncime minimă $-0,40 \mathrm{~m}$ faţă de nivelul actual de călcare; orientare SV-NE; schelet în decubit dorsal, bine conservat, cu excepția craniului dislocat la săparea mecanică a şanţului, dar recuperat, şi a părții stângi a coastelor; ambele antebrațe pe piept, aproape de clavicule; L în groapă, fără craniul dislocat $-1,50 \mathrm{~m}$; fără inventar, dar a fost descoperit un cartuş în zona picioarelor; a secționat o amenajare gen podea de pământ galben; încadrare cronologică: epoca modernă; caracteristici antropologice: prezintă craniu (glabelă grad +1 , mastoide grad 0 , diametru antero-posterior maxim 179,32 $\mathrm{mm}$ lung, diametru transversal maxim $134,42 \mathrm{~mm}$ foarte îngust, indice cranian orizontal 74,96 dolicocran), hemimandibulă stângă (unghi mandibular grad 1), clavicule $(\operatorname{Lmax}=152,98 \mathrm{~mm} / 146,54 \mathrm{~mm}$, asimetrie), scapule (lipsă fragmente de la nivelul corpurilor), humerusuri $(\operatorname{Lmax}=314,77$ $\mathrm{mm} / 315,51 \mathrm{~mm}$, faza I), radiusuri $(\operatorname{Lmax}=231,13$ $\mathrm{mm} / 233,77 \mathrm{~mm})$, ulne $(\operatorname{Lmax}=242,67$ $\mathrm{mm} / 248,78 \mathrm{~mm}$, asimetrie), vertebre, coaste, coxale (ilioane), femur stâng (diafiză), femur drept $(\operatorname{Lmax}=421,42 \mathrm{~mm}$, faza II), tibii (Lmax = $358,30 \mathrm{~mm} / 356,37 \mathrm{~mm}$ ), fibulă stângă (lipsă epifiză distală), fibulă dreaptă $(\operatorname{Lmax}=337,38$ $\mathrm{mm}$ ), metacarpiene, metatarsiene şi falange; sex: probabil feminin (oase scurte, gracile, suprafață netedă); vârstă: cca. 42,5 ani, maturus II; talie: cca. $156,74 \mathrm{~cm}$, supramijlocie; elemente de patologie: exostoză la nivelul treimii anterioare distale humerale stângi; 80a) a mai fost identificat un femur stâng (lipsă epifiză distală, mare, gros, faza II); sex: probabil masculin; vârstă: cca. 44 ani, maturus II; fig. 20; 21/2;

81) M 2 - cpl. 64 / Str. Bisericii, zona Căminului cultural, 2006, şanț pentru alimentarea cu apă a satului de pe latura vestică a străzii, la N de M 1 (cpl. 63) - mormânt de inhumație; casetă practicată în malul $\mathrm{E}$ al şanțului pentru alimentarea cu apă; adâncime minimă $-0,47 \mathrm{~m}$ față de nivelul actual de călcare; craniu; L - 0,22 m; fără inventar; încadrare cronologică: epoca modernă; caracteristici antropologice: prezintă craniu (fragmentar, mastoide grad -1, linii nucale slab dezvoltate), mandibulă (lipsă corpuri mandibulare din dreptul molarilor), vertebre (câteva), rotule (linii puțin clare la nivelul suprafeței anterioare) şi metatarsiene; sex: feminin; categorie de vârstă: adultus/adult (grad mediu de obliterare a suturilor craniene); elemente de patologie: carie la nivelul caninului inferior dreapta; fig. 20; 21/6;

82) M 3 - cpl. 65 / Str. Bisericii, zona Căminului cultural, 2006, şanț pentru alimentarea cu apă a satului de pe latura vestică a străzii, la N de M 2 (cpl. 64) - mormânt de inhumație; casetă practicată în malul $\mathrm{E}$ al şanţului pentru alimentarea cu apă; adâncime minimă $-0,55 \mathrm{~m}$ față de nivelul actual de călcare; orientare SV$\mathrm{NE}$; schelet în decubit dorsal, din care au fost descoperite in situ doar oasele membrelor inferioare, restul scheletului fiind probabil dislocat la săparea mecanică a şanţului; L surprinsă în şanț $-0,84 \mathrm{~m}$; fără inventar în porțiunea cercetată; încadrare cronologică: epoca modernă; caracteristici antropologice: prezintă 
femur stâng (Lmax $=431,99 \mathrm{~mm}$, faza I), femur drept (lipsă epifiză proximală), tibii (Lmax = $363,62 \mathrm{~mm} / 362,72 \mathrm{~mm}$ ), fibulă stângă (treime distală), fibulă dreaptă $(\operatorname{Lmax}=356,59 \mathrm{~mm})$, metatarsiene şi falange; sex: feminin (oase relativ scurte, gracile, suprafață netedă, fără de detalii anatomice evidente); vârstă: cca. 33 ani, maturus I; talie: cca. 158,20 cm, supramijlocie; fig. 20; 21/3-4;

83) M 4 - cpl. 66 / Str. Bisericii, zona Căminului cultural, 2006, şanț pentru alimentarea cu apă a satului de pe latura vestică a străzii, sub M 3 (cpl. 65), casetă practicată în malul E al şanțului pentru alimentarea cu apă - mormânt de inhumație; adâncime minimă $-0,69 \mathrm{~m}$ față de nivelul actual de călcare; orientare V-E; schelet în decubit dorsal, bine conservat; partea superioară a scheletului probabil dislocată la săparea mecanică a şanțului; descoperit in situ în partea sa inferioară - cinci vertebre deasupra osului sacru, bazinul, membrele inferioare; tibiile şi peroneele sunt deplasate şi au poziția inversată, probabil din cauza presiunii pământului şi a mormântului amenajat deasupra M 4; L surprinsă în şanț - 1,19 m; amprente de lemn de la sicriu de o parte şi de alta a scheletului şi sub acesta; la $0,21 \mathrm{~m} \mathrm{~S}$ față de bazinul scheletului se constată urmele unei vetre constând în cenuşă albicioasă; fără inventar; încadrare cronologică: epoca modernă; caracteristici antropologice: prezintă vertebre, sacrum (curbă ventrală puțin clară, larg), coxale (pubisuri distruse, ilion divergent lateral), femur stâng (lipsă fragmente de cap femural), femur drept $(\operatorname{Lmax}=431,80 \mathrm{~mm}$, faza III), tibii $(\operatorname{Lmax}=348,82 \mathrm{~mm} / 348,36 \mathrm{~mm})$, fibule $(\operatorname{Lmax}=$ $338,55 \mathrm{~mm} / 339,81 \mathrm{~mm}$ ), metatarsiene şi falange; sex: feminin (oase subțiiri, gracile); vârstă: cca. 52 ani, senilis I; talie: cca. 155,67 cm, mijlocie; fig. $20 ; 21 / 6$;

84) M 5 - cpl. 67 / Str. Bisericii, zona Căminului cultural, 2006 - mormânt de inhumaţie; casetă practicată în malul E al şanţului pentru alimentarea cu apă de pe latura vestică a străzii; adâncime minimă $-0,80 \mathrm{~m}$ față de nivelul actual de călcare; orientare SV-NE; schelet în decubit dorsal, din care au fost descoperite in situ doar oasele membrelor inferioare, restul scheletului fiind probabil dislocat la săparea mecanică a şanțului şi recuperat; L surprinsă în şanț $-0,43 \mathrm{~m}$; fără inventar în porțiunea cercetată; încadrare cronologică: epoca modernă; caracteristici antropologice: prezintă scapulă dreaptă (lipsă fragmente corp), humerus stâng (Lmax $=254,02 \mathrm{~mm}$, faza II), radius stâng (Lmax $=187,24 \mathrm{~mm}$ ), coxal stâng (foramen obturat triunghiular, jos, lat, cu margini ascuțite, acetabulum mic, poziționat antero-lateral, fațetă simfizară faza II), femur stâng ( $\operatorname{Lmax}=364,61$ mm, faza II), tibie stângă (Lmax $=306,38 \mathrm{~mm}$ ), tibie dreaptă (lipsă epifiză proximală), fibule (Lmax $=297,63 \mathrm{~mm} / 296,40 \mathrm{~mm}$ ) şi metatarsiene; sex: feminin; vârstă: cca. 46,33 ani, maturus II; talie: cca. 142,09 cm, mică; fig. 20; 21/3;

85) M 6 - cpl. 69 / Str. Bisericii, zona Căminului cultural, 2006, la N faţă de M 5 (cpl. 68) - mormânt de inhumație; casetă practicată atât în malul $\mathrm{E}$, cât şi în cel $\mathrm{V}$ al şanțului pentru alimentarea cu apă de pe latura vestică a străzii; adâncime minimă $-0,62 \mathrm{~m}$ faţă de nivelul actual de călcare; orientare $\mathrm{SV}-\mathrm{NE}$; schelet în decubit dorsal, bine conservat; craniul pe partea stângă; antebrațul drept pe umăr, oasele brațului stâng depuse lângă tibia şi peroneul drept, în dreapta acestora; lipseşte coxalul drept şi osul sacru, probabil din cauza săpării mecanice a şanțului; femurul drept rupt şi deplasat spre S; coloana vertebrală uşor curbată; L în groapă $-1,79 \mathrm{~m}$; fără inventar; încadrare cronologică: epoca modernă; caracteristici antropologice: prezintă craniu (glabelă şi mastoide grad +1 , diametru anteroposterior 195,91 $\mathrm{mm}$ foarte lung, diametru transversal maxim 145,93 mm îngust, indice cranian orizontal 74,48 dolicocran), mandibulă (unghiuri mandibulare şi menton grad +2 ), claviculă dreaptă $(\operatorname{Lmax}=162,87 \mathrm{~mm})$, scapulă dreaptă (lipsă fragmente corp, lungă şi foarte robustă), humerusuri ( $\operatorname{Lmax}=350,19 \mathrm{~mm} / 351,96$ $\mathrm{mm}$, faza III), radiusuri $(\operatorname{Lmax}=267,61 \mathrm{~mm} /$ $270,43 \mathrm{~mm})$, ulne $(\operatorname{Lmax}=295,27 \mathrm{~mm} / 296,25$ $\mathrm{mm}$ ), vertebre, coaste, coxal stâng (de dimensiuni mari, şanț sciatic grad +1 , fațetă simfizară pubică faza III), femur stâng ( $\operatorname{Lmax}=480,22 \mathrm{~mm}$, faza III), femur drept (treime distală spartă), tibii $(\operatorname{Lmax}=398,41 \mathrm{~mm} / 398,60 \mathrm{~mm})$, fibule $(\mathrm{Lmax}=$ $387,42 \mathrm{~mm} / 388,51 \mathrm{~mm}$ ), metatarsiene şi falange; sex: masculin; vârstă: cca. 53,66 ani, senilis I; talie: cca. 171,10 cm, mare; fig. 20; 21/5;

86) M 7 - cpl. 70 / Str. Bisericii, zona Căminului cultural, 2006, la N de M 6 (cpl. 69), la $0,25 \mathrm{~m}$ distanţă spre E față de stâlpul electric mormânt de inhumație; şanț $\mathrm{V}$ pentru alimentarea cu apă; nu s-a practicat casetă din cauza apropierii 
periculoase de stâlpul electric; adâncime minimă $0,89 \mathrm{~m}$ față de nivelul actual de călcare; orientare SV-NE; schelet în decubit dorsal, bine conservat, din care a fost surprinsă în şanț doar zona bazinului şi a femurelor, restul scheletului pătrunzând sub ambele maluri ale şanțului; capetele vizibile ale oaselor antebrațului stâng pe abdomen, deasupra bazinului; L surprinsă în şanț $-0,65 \mathrm{~m}$; fără inventar în porțiunea cercetată; încadrare cronologică: epoca modernă; caracteristici antropologice: prezintă o coastă, stern, sacrum (larg, scurt, puțin arcuit), coxale (şanţ sciatic şi unghi pubian grad -1, bazin de forma unei arcade foarte curbate, fațete simfizare pubice faza I), femure (Lmax $=408,22 \mathrm{~mm} / 408,29 \mathrm{~mm}$, faza I) şi falange; sex: feminin; vârstă: cca. 32,5 ani, maturus I; talie: cca. $151,19 \mathrm{~cm}$, submijlocie; fig. $20 ; 22 / 1$;

87) $M$ / Str. Bisericii, zona Căminului cultural, 2006 - oase umane recuperate din preajma M 1 (cpl. 63), fără înregistrarea situației arheologice; încadrare cronologică probabilă: epoca modernă; caracteristici antropologice: resturi osteologice ce provin de la doi indivizi: 1) prezintă craniu (un fragment de frontal), claviculă stângă (jumătate medială), humerus drept (cap humeral, fragmente de diafiză, lipsă epifiză distală), radiusuri $(\operatorname{Lmax}=234,47 \mathrm{~mm} / 235,40 \mathrm{~mm}$, gracile, subțiri), ulne $(\operatorname{Lmax}=256,33 \mathrm{~mm} / 256,89$ $\mathrm{mm}$, gracile, subțiiri), vertebre, coaste, coxal drept (,golf" pelvic eliptic, foramen obturat triunghiular, jos, fațetă simfizară pubică faza IV), femur stâng (faza IV), metacarpiene, metatarsiene şi falange; sex: feminin; vârstă: cca. 59 ani, senilis I; talie: cca. 158,45 cm, supramijlocie; 2) prezintă femur drept (diafiză femurală), tibie dreaptă (lipsă epifiză distală), fibulă dreaptă (lipsă epifiză proximală) şi calcaneu stâng; sex: masculin (oase masive, epifize mari); vârstă: peste 19 ani, juvenis/adult (epifize fuzionate);

88) $M$ / Str. Bisericii, zona Căminului cultural, 2006 - oase umane recuperate din preajma M 3 (cpl. 65), fără înregistrarea situației arheologice; încadrare cronologică probabilă: epoca modernă; caracteristici antropologice: prezintă hemimandibulă dreaptă (unghi mandibular grad 2), claviculă stângă (Lmax $=168,24$ mm, lungă, groasă, curbură în formă de „S” proeminentă şi detalii anatomice evidente), scapulă stângă (mare, puternică), vertebre, coaste, rotulă stângă şi calcaneu stâng (masiv); sex: masculin; categorie de vârstă: adultus/adult (epifize fuzionate);

89) $\mathrm{M} /$ Str. Bisericii, zona Căminului cultural, 2006 - oase umane recuperate din preajma M 6 (cpl. 69), fără înregistrarea situației arheologice; încadrare cronologică probabilă: epoca modernă; caracteristici antropologice: resturi osteologice ce provin de la patru indivizi: 1) prezintă craniu (două fragmente de calotă craniană), humerus stâng (lipsă epifiză proximală), humerus drept $(\operatorname{Lmax}=214,53 \mathrm{~mm})$, ulnă stângă (lipsă epifiză distală), sacrum, coxal drept (ilion) şi femur drept (lipsă epifiză proximală); vârstă: cca. 7,5-8,5 ani, infans II (după lungimile maxime ale oaselor lungi); 2) prezintă claviculă dreaptă (diafiză), humerus stâng (epifiză distală), humerus drept (fragmente de diafiză), radius drept (jumătate proximală), ulnă dreaptă (jumătate proximală), coxal stâng (şanț sciatic grad -1 , fațetă simfizară pubică faza I), coxal drept (ilion), femure (diafize, subțiiri), rotulă stângă, tibie stângă $(\operatorname{Lmax}=330,92 \mathrm{~mm})$, tibie dreaptă (lipsă fragmente de epifiză proximală), fibule $(\operatorname{Lmax}=325,38 \mathrm{~mm} / 328,27 \mathrm{~mm})$, metacarpiene, metatarsiene şi falange; sex: feminin; vârstă: cca. 32 ani, maturus I; talie: cca. $151,36 \mathrm{~cm}$, submijlocie; 3) prezintă ulnă stângă $(\operatorname{Lmax}=90,78 \mathrm{~mm})$; vârstă: cca. $0,5-1,5$ ani, infans I (pe baza lungimii maxime); 4) prezintă sacrum (arcuit, îngust, sudat); sex masculin; categorie de vârstă: adultus/adult (vertebre sudate);

90) M / Str. Bisericii 93, la N de Căminul cultural, 2006 - craniu uman pe malul E al şanțului pentru alimentare cu apă de pe latura vestică a străzii, în dreptul $\mathrm{m} 4,30$ de la stâlpul de tensiune de la $\mathrm{N}$ de căminul cultural; adâncime $0,40 \mathrm{~m}$ faţă de nivelul actual de călcare; nerecuperat; încadrare cronologică probabilă: epoca modernă;

91) M / Str. Bisericii 93, la N de Căminul cultural, 2006 - un femur uman recuperat, fără sesizarea urmei complexului pe profilul şanţului pentru alimentare cu apă; adâncime probabilă 0,60-0,90 m; încadrare cronologică probabilă: epoca modernă; caracteristici antropologice: prezintă femur drept $(\operatorname{Lmax}=403,08 \mathrm{~mm}$, scurt, suprafaţă netedă, gracilă, linea aspera slab dezvoltată, faza I); sex: feminin; vârstă: cca. 33 ani, maturus I; talie: cca. 150,18 cm, submijlocie; 


\section{STR. BISERICII, ZONA ZIDULUI DE} INCINTĂ SUDIC

92) M 1 / Str. Bisericii 169, 1981, S 1 Fortificație Cămin, caseta A, c. 3 - mormânt de inhumație; adâncime minimă $-0,85 \mathrm{~m}$ față de nivelul actual de păstrare a zidului de incintă (= nivelul actual de călcare); orientare $\mathrm{V}-\mathrm{E}$; schelet probabil de adult a cărui parte superioară, de la bazin în sus, pătrunde în malul V, în decubit dorsal, bine conservat; fără inventar; încadrare cronologică: epoca medio-bizantină;

93) M 2 / Str. Bisericii 169, 1981, S 1 Fortificație Cămin, caseta B, c. 8/9 - mormânt de inhumație; orientare $\mathrm{E}-\mathrm{V}$; schelet a cărui mandibulă pătrunde în malul $\mathrm{V}$, restul extinzânduse spre cel E, în decubit dorsal; fără inventar; încadrare cronologică: epoca medio-bizantină;

94) M 3 / Str. Bisericii 169, 1981, S 1 Fortificație Cămin, caseta B, c. 9, sub nivelul gropii 2 - mormânt de inhumație; adâncime minimă $-1,20$ $\mathrm{m}$ față de nivelul actual de păstrare a zidului de incintă (= nivelul actual de călcare); orientare V-E; schelet probabil de adult, în decubit dorsal, a cărui parte inferioară, de la coate în jos, pătrunde în malul $\mathrm{E}$; L în secțiune - 0,55 m; fără inventar; încadrare cronologică: epoca medio-bizantină;

95) M 4 / Str. Bisericii 169, 1981, S 1 Fortificație Cămin, caseta B, c. 7, sub nivelul gropii 2, lângă malul V - mormânt de inhumație; adâncime minimă $-1,45 \mathrm{~m}$ faţă de nivelul actual de păstrare a zidului de incintă (= nivelul actual de călcare); orientare neclară; schelet probabil de adult, în decubit dorsal, parțial păstrat; fără inventar; distrus parțial de groapă?; încadrare cronologică: epoca medio-bizantină; fig. 14;

96) M 5 / Str. Bisericii 169, 1981, S 1 Fortificație Cămin, caseta B, c. 6, lângă zid mormânt de inhumație; adâncime minimă $-1,15 \mathrm{~m}$ faţă de nivelul actual de păstrare a zidului de incintă (= nivelul actual de călcare); orientare V-E; schelet probabil de adult, în decubit dorsal, bine conservat, a cărui parte superioară, de la bazin în sus, a fost distrusă; ambele antebrațe întinse pe lângă corp; L în secțiune - $1 \mathrm{~m}$; fără inventar; încadrare cronologică: epoca medio-bizantină; fig. 14;

97) M 6 / Str. Bisericii 169, 1981, S 1 Fortificație Cămin, caseta A - mormânt de inhumație; adâncime minimă $-0,60 \mathrm{~m}$ față de nivelul actual de păstrare a zidului de incintă (= nivelul actual de călcare); suprapune parțial M 7; orientare $\mathrm{V}-\mathrm{E}$; schelet în decubit dorsal; fără inventar; încadrare cronologică: epoca modernă; caracteristici antropologice: prezintă craniu (fragmentar), hemimandibulă dreaptă (unghi mandibular şi menton grad +1$)$, clavicule $(\operatorname{Lmax}=$ $148,07 \mathrm{~mm} / 150,12 \mathrm{~mm}$ ), scapule (fragmentare), humerus stâng (lipsă fragmente de epifiză proximală), humerus drept $(\operatorname{Lmax}=322,05$, faza II), radius stâng (Lmax $=247,95 \mathrm{~mm})$, radius drept (lipsă fragmente de epifiză proximală), ulnă stângă $(\operatorname{Lmax}=271,01 \mathrm{~mm})$, ulnă dreaptă (lipsă fragmente de epifiză proximală), vertebre, coaste, stern, sacrum (fațete auriculare ce se întind până în dreptul segmentului al treilea), coxale (pubisuri distruse, şanțuri sciatice grad +1 ), femure (Lmax $=433,56 \mathrm{~mm} / 433,89 \mathrm{~mm}$, faza II), tibie stângă (lipsă fragmente de diafiză), metacarpiene, metatarsiene şi falange; sex: masculin; vârstă: cca. 47,5 ani, maturus II; talie: cca. $162,50 \mathrm{~cm}$, submijlocie; elemente de patologie: carie la unul dintre molari, exostoze la nivelul epifizelor distale ulnare şi radiale drepte; fig. 14;

98) M 7 / Str. Bisericii 169, 1981, S 1 Fortificație Cămin, caseta A, suprapus de M 6 mormânt de inhumație; suprapus de M 6; orientare $\mathrm{V}-\mathrm{E}$; schelet de copil, în decubit dorsal; inventar: trei brățări de sticlă albastre; încadrare cronologică: epoca medio-bizantină (sec. XI); fig. 4;

99) M $1 /$ Str. Bisericii 93, 2006, S 2 Fortificație Cămin, caseta $\mathrm{B}$, jumătatea $\mathrm{V}$ - mormânt de inhumație; la $0,48 \mathrm{~m}$ distanță spre $\mathrm{S}$ faţă de zidul de incintă sudic; adâncime minimă $-0,90$ m față de nivelul actual de păstrare a zidului de incintă (= nivelul actual de călcare); orientare $\mathrm{V}-\mathrm{E}$; schelet în decubit dorsal, bine conservat, surprins în şanț de la bazin (inclusiv) în jos, restul scheletului pătrunzând în malul V al casetei; capetele vizibile ale oaselor antebrațului drept pe bazin; picioarele întinse; L (parțială) surprinsă în groapă $-1,13 \mathrm{~m}$; groapa mormântului a fost săpată într-o amenajare de lut galben; inventar posibil: o verigă simplă, bronz, în zona piciorului stâng, mai probabil antrenată de săparea gropii menajere din zonă; încadrare cronologică: epoca medio-bizantină; caracteristici antropologice: prezintă radius drept $(\operatorname{Lmax}=262,33$ $\mathrm{mm}$ ), ulnă dreaptă (treime proximală), coaste (fragmente), vertebre (fragmente), stern (corp), sacrum (S1), coxale (ilioane), femure (diafize), tibie stângă (?) (jumătate distală), tibie dreaptă (lipsă epifiză proximală), fibulă stângă (diafiză), fibulă 
dreaptă (jumătate proximală), calcanee, astragal stâng şi falange; sex: masculin (oase lungi masive, groase, bogate în detalii anatomice, epifize mari, multe locuri de inserție musculară, linii, gropi); vârstă: peste 20 ani, juvenis/adultus (epifize fuzionate; sacrum nesudat complet); talie: cca. $169,47 \mathrm{~cm}$, supramijlocie; fig. 15; 17/1;

100) M 2 / Str. Bisericii 93, 2006, S 2 Fortificație Cămin, caseta B, mijlocul casetei mormânt de inhumație; la 1,10 m distanță spre S față de zidul de incintă sudic; adâncime minimă 1,08 m față de nivelul față de nivelul actual de păstrare a zidului de incintă (= nivelul actual de călcare); orientare $\mathrm{V}-\mathrm{E}$; schelet probabil în decubit dorsal din care se mai păstrează ]n conexiune anatomică doar craniul, omoplatul, sternul şi humerus-ul stângi, restul scheletului fiind distrus de o groapă ulterioară; craniul în poziție normală; L surprinsă în groapă - 0,45 m; groapa mormântului a fost săpată într-o amenajare de lut galben; cărbune sub craniu; fără inventar; încadrare cronologică: epoca medio-bizantină; caracteristici antropologice: prezintă craniu (fragmentar), mandibulă (menton grad -1), claviculă dreaptă $(\operatorname{Lmax}=124,85 \mathrm{~mm}$, scurtă, gracilă), scapulă stângă, humerus stâng (Lmax = 281,94 mm, faza IV), vertebre, stern şi metacarpiene; sex: feminin; vârsta: cca. 59 ani, senilis I; talie: cca. $147,82 \mathrm{~cm}$, mică; elemente de patologie: carie la nivelul molarului 2 inferior dreapta; fig. 15; 17/2;

101) M 3 / Str. Bisericii 93, 2006, S 2 Fortificație Cămin, caseta B, jumătatea V mormânt de inhumație, la $0,55 \mathrm{~m}$ distanță la $\mathrm{S}$ față de zidul de incintă sudic; adâncime minimă $-1,31$ m față de nivelul actual de păstrare a zidului de incintă (= nivelul actual de călcare); orientare VE; schelet bine conservat, în decubit dorsal; craniul pătrunde în malul vestic al casetei, un rest vizibil de mandibulă; antebraţul drept pe abdomen, antebrațul stâng pe bazin; picioarele întinse; L (parțială) în groapă (fără craniu) - 1,47 m; inventar: două mărgele de sticlă albastră în zona mandibulei şi o mărgică de chihlimbar; încadrare cronologică: epoca medio-bizantină; caracteristici antropologice: prezintă scapulă dreaptă (cavitate glenoidă şi acromion), radius drept (lipsă epifiză distală), vertebre (câteva), sacrum (aproximativ întreg, larg, scurt, puțin arcuit), coxal stâng (şanț sciatic grad -1), femure (lipsă epifize distale, linea aspera slab evidențiată), tibii (jumătăți distale), fibulă stângă (epifize), fibulă dreaptă (epifize şi o diafiză), metatarsiene şi falange; sex: feminin (oase gracile, de dimensiuni mici); vârstă: peste 20 ani, juvenis/adult (epifize fuzionate); fig. 16; 17/3;

102) M 4 / Str. Bisericii 93, 2006, S 2 Fortificație Cămin, caseta $\mathrm{B}$, jumătatea $\mathrm{V}$ - mormânt de inhumație; la 1,55 m distanță spre $\mathrm{S}$ de zidul de incintă sudic şi la 0,62 m sud faţă de M 3 / S 2 Fortificație Cămin, cu care este paralel, reprezentând un al doilea şir; adâncime minimă $-1,30 \mathrm{~m}$ faţă de nivelul faţă de nivelul actual de păstrare a zidului de incintă (= nivelul actual de călcare); orientare V-E; schelet în decubit dorsal, bine conservat, din care au fost surprinse în şanţ bazinul (parţial) şi membrele inferioare, restul scheletului pătrunzând în malul V al casetei; picioarele întinse; L (parţială) în groapă 0,95 m; fără inventar; încadrare cronologică: epoca medio-bizantină; caracteristici antropologice: prezintă coxale (ilioane), femure (Lmax $=430,19$ $\mathrm{mm} / 430,73 \mathrm{~mm}$, faza II), tibii (Lmax $=356,28$ $\mathrm{mm} / 356,55 \mathrm{~mm})$, fibulă stângă (Lmax $=353,83$ mm), fibulă dreaptă (lipsă epifiză proximală), calcanee, astragale, metatarsiene şi falange; sex: feminin (oase puțin masive, subțiri, suprafață netedă, rotunjită şi gracilă); vârstă: cca. 44 ani, maturus II; talie: cca. 156,57 cm, supramijlocie; fig. 16; 17/3;

103) M 5 / Str. Bisericii 93, 2006, S 2 Fortificaţie Cămin, caseta $\mathrm{B}$, jumătatea $\mathrm{V}$ mormânt de inhumație; orientare V-E; încadrare cronologică: epoca medio-bizantină; caracteristici antropologice: prezintă craniu (fragmente), mandibulă (corpuri), radius drept (Lmax $=60,67$ mm), ulnă stângă (lipsă epifiză proximală), ulnă dreaptă $(\operatorname{Lmax}=68,56 \mathrm{~mm})$, vertebre, coaste, stern, coxale (ilioane, pubis stâng), femur stâng (jumătate distală), tibii (jumătăți proximale) şi metatarsiene; vârstă: cca. 0-0,5 ani, infans I (după lungimile maxime ale oaselor lungi);

104) M 1 / Str. Bisericii 93, 2006, S 2 Fortificație Cămin, caseta A, jumătatea E mormânt de inhumație; la $0,80 \mathrm{~m}$ distanţă spre V față de malul E al casetei; adâncime $-0,40$ m față de nivelul actual de păstrare a zidului de incintă (= nivelul actual de călcare); lângă paramentul nordic al zidului de incintă sudic; orientare probabilă V-E; mormânt distrus în momentul săpării casetei; deasupra nivelului locuinței cu bază de piatră; grupaj de oase umane recuperate; fără inventar; încadrare cronologică probabilă: epoca modernă; 
caracteristici antropologice: resturi osteologice ce provin de la cel puțin nouă (?) indivizi: prezintă craniu (fragmente, maxilar stâng), claviculă dreaptă, două scapule drepte, 11 humerusuri (patru întregi, Lmax $=158,60 \mathrm{~mm}, 162,31$ $\mathrm{mm} / 163,40 \mathrm{~mm}, 79,24 \mathrm{~mm}$ şi şapte fragmente), şase radiusuri (două întregi, Lmax $=174,24$ mm, $112,87 \mathrm{~mm}$ şi patru fragmente), trei ulne (Lmax $=$ .../61,64 mm, 83,04 mm), coaste, şapte femure (trei întregi, Lmax $=134,61 \mathrm{~mm}, 61,89 \mathrm{~mm}$, $75,97 \mathrm{~mm}$ şi patru fragmente), patru tibii (fragmente), un metatarsian şi o falangă, pe care nu le-am putut atribui cu exactitate unuia dintre indivizi; vârste şi categorii de vârstă: cca. 0-0,5 ani (doi indivizi), cca. 0,5-1,5 ani (un individ), cca. 2,5-3,5 ani (un individ), cca. 3,5-4,5 ani (un individ), cca. 4,5-5,5 ani (un individ), cca. 7,59,5 ani (un individ) - după lungimile maxime ale oaselor lungi -, infans I (şapte), infans II (unul) şi adultus/adult (după o diafiză femurală de dimensiuni mari);

105) M $2 /$ Str. Bisericii 93, 2006, S 2 Fortificație Cămin, caseta A, jumătatea E - mormânt de inhumație; la 0,40 m distanță spre $\mathrm{V}$ față de malul E al casetei; adâncime minimă $-0,83 \mathrm{~m}$ față de nivelul actual de păstrare a zidului de incintă (= nivelul actual de călcare); lângă paramentul nordic al zidului de incintă sudic; orientare probabilă V-E; mormânt distrus în momentul săpării casetei; deasupra nivelului locuinței cu bază de piatră; oase umane recuperate; fără inventar; încadrare cronologică probabilă: epoca modernă; caracteristici antropologice: resturi osteologice ce provin de la doi indivizi: 1) prezintă craniu (fragmente), coaste (fragmente) şi femur stâng (lipsă epifiză proximală); categorie de vârstă: infans I (prin comparaţie dimensională cu alte oase aparținând grupei infans I); 2) prezintă tibie stângă (diafiză); categorie de vârstă: adultus/adult (os de dimensiuni relativ mari);

106) M 3 / Str. Bisericii 93, 2006, S 2 Fortificaţie Cămin, caseta A, jumătatea E mormânt de inhumație; la 0,35 m distanță spre N faţă de zidul de incintă sudic; la $2 \mathrm{~m}$ distanţă spre V față de malul E al casetei; adâncime minimă $-0,82$ $\mathrm{m}$ față de nivelul actual de păstrare a zidului de incintă (= nivelul actual de călcare); orientare probabilă V-E; mormânt distrus în momentul săpării casetei; pare a fi în interiorul locuinței cu bază de piatră; oase umane recuperate; fără inventar; încadrare cronologică probabilă: epoca modernă; caracteristici antropologice: resturi osteologice ce provin de la doi indivizi: 1) prezintă craniu (un fragment de parietal stâng) şi o coastă; categorie de vârstă: infans I (prin comparație dimensională cu alte oase aparținând grupei infans I); 2) prezintă un astragal stâng; categorie de vârstă: adultus/adult (os de dimensiuni relativ mari);

107) M 4 / Str. Bisericii 93, 2006, S 2 Fortificație Cămin, caseta $\mathrm{A}$, jumătatea $\mathrm{E}$ - mormânt de inhumație; la 1,40 m distanţă spre $\mathrm{N}$ față de zidul de incintă sudic; adâncime minimă $-1,10$ m faţă de nivelul actual de păstrare a zidului de incintă (= nivelul actual de călcare); orientare probabilă V-E; s-a cercetat şi recuperat doar craniul, restul scheletului pătrunzând în malul E; fără inventar în porțiunea cercetată; încadrare cronologică: epoca medio-bizantină; caracteristici antropologice: prezintă craniu (câteva fragmente, pereți cranieni relativ groşi); sex: probabil masculin; categorie de vârstă: adultus/adult (grad mediu de obliterare a suturilor craniene);

108) M 5 / Str. Bisericii 93, 2006, S 2 Fortificație Cămin, caseta A, jumătatea E mormânt de inhumație; la 0,18 m distanță la N faţă de zidul de incintă sudic; adâncime minimă $-0,97$ m față de nivelul actual de păstrare a zidului de incintă (= nivelul actual de călcare); orientare VE; schelet în decubit dorsal, bine conservat, dar cu vertebrele, coastele şi bazinul fragile; craniul aplecat pe partea stângă; antebrațul drept pe bazin, antebrațul stâng pe piept; picioarele întinse, cu tibiile şi peroneele încrucişate, stângul peste dreptul; L în groapă - 1,44 m; groapa mormântului a fost amenajată în pământul care acoperă plinta zidului, deasupra acesteia; amprente de lemn de la sicriu între rotula dreaptă şi plinta zidului; fără inventar; încadrare cronologică: epoca medio-bizantină; caracteristici antropologice: prezintă craniu (glabelă şi mastoide grad +1 , diametru anteroposterior maxim 175,69 $\mathrm{mm}$ scurt, diametru transversal maxim 156,37 mm lat, indice cranian orizontal 89,00 hiperbrahicran), mandibulă (unghiuri mandibulare şi menton grad +1 ), clavicule (corpuri, robuste), scapule (acromioane), humerusuri (lipsă epifize proximale), radius stâng (lipsă epifiză proximală), radius drept (Lmax = 239,40 mm), ulnă stângă (distrusă), ulnă dreaptă $($ Lmax $=267,14 \mathrm{~mm})$, vertebre, coaste, stern (manubriu), sacrum (spart), femur stâng (lipsă epifiză distală, faza II), femur drept (jumătate distală), tibii (lipsă epifize proximale), fibulă stângă (lipsă epifiză proximală), fibulă dreaptă 
(lipsă epifiză distală), metacarpiene şi metatarsiene; sex: masculin; vârstă: cca. 44 ani, maturus II; talie: cca. $161,98 \mathrm{~cm}$, submijlocie; fig. $16 ; 17 / 4$;

109) M 6 / Str. Bisericii 93, 2006, S 2 Fortificație Cămin, caseta A, jumătatea E mormânt de inhumație; la 1,10 m distanță la N față de zidul de incintă sudic; la 0,45 m distanță spre N faţă de M 5, formând un al doilea şir; adâncime minimă $-1,25 \mathrm{~m}$ față de nivelul actual de păstrare a zidului de incintă (= nivelul actual de călcare); orientare V-E; schelet în decubit dorsal, bine conservat; craniul deteriorat, cu mandibula bine păstrată, în poziție normală; antebrațul drept pe piept, antebraţul stâng pe abdomen, deasupra bazinului; picioarele întinse; L în groapă - 1,60 m; groapa mormântului a fost amenajată în pământul care acoperă plinta zidului, puțin mai jos faţă de nivelul de înhumare al M 5; urme de lemn de la sicriu în dreptul cotului stâng; fără inventar; încadrare cronologică: epoca mediobizantină; caracteristici antropologice: prezintă craniu (fragmente), mandibulă, claviculă stângă (Lmax = 162,44 mm, lungă, groasă, locuri de inserție musculară evidente), claviculă dreaptă (lipsă extremitate medială), scapulă stângă (aproximativ întreagă), scapulă dreaptă (acromion), humerus stâng (lipsă epifiză distală), humerus drept (lipsă epifiză proximală, fragmentar), radius stâng (Lmax $=236,50 \mathrm{~mm}$ ), ulne (jumătăți proximale), radius drept (diafiză), vertebre, coaste, stern (manubriu), coxal drept (fragmentar, şanț sciatic grad +1 ), femure (Lmax $=445,00 \mathrm{~mm} / 443,25 \mathrm{~mm}$, faza IV), rotulă stângă, tibie stângă (lipsă epifiză distală), tibie dreaptă (Lmax $=369,23 \mathrm{~mm}$ ), fibule (diafize), calcanee, astragale şi falange; sex: masculin (oase lungi groase, epifize mari); vârstă: cca. 58 ani, senilis I; talie: cca. 163,14 cm, submijlocie; fig. 16; 17/4;

STR. BISERICII, ZONA MAGAZINULUI DIN DREPTUL INTERSECŢIEI CU DJ 222 C

110) $M 1$ / Str. Bisericii, 2006, şanţ pentru alimentare cu apă pe latura vestică a străzii, zona magazinului din capătul $\mathrm{N}$ al străzii, în dreptul scării de acces - mormânt de inhumație; vizibil pe malul E al şanţului pentru alimentarea cu apă; adâncime minimă $-0,60-0,80 \mathrm{~m}$ faţă de nivelul actual de călcare; orientare NV-SE; suprapune o groapă menajeră; nu au fost recuperate oase; încadrare cronologică probabilă: epoca modernă;

111) M 2 / Str. Bisericii, 2006, şanţ pentru alimentare cu apă pe latura vestică a străzii, zona magazinului din capătul $\mathrm{N}$ al străzii, la $\mathrm{S}$ de scara de acces - mormânt de inhumație, vizibil pe malul E al şanţului pentru alimentarea cu apă; adâncime minimă $-0,60-0,80 \mathrm{~m}$ față de nivelul actual de călcare; orientare NV-SE; suprapune o groapă menajeră; încadrare cronologică probabilă: epoca modernă; caracteristici antropologice: resturi osteologice ce provin de la trei indivizi: 1) prezintă craniu (fragmente de calotă, pereți cranieni groşi), humerus stâng (jumătate proximală, groasă, de dimensiuni mari), sacrum (îngust, lung), femur stâng (lipsă epifiză proximală, mare, gros, detalii anatomice evidente) şi femur drept (epifiză proximală, faza II); sex: masculin; vârstă: cca 44 ani, maturus II; 2) prezintă femur stâng (lipsă treime distală) şi femur drept (lipsă epifiză distală, faza I); sex: feminin (oase gracile, subțiri, fără detalii anatomice evidente); vârstă: cca. 33 ani, maturus I; 3) prezintă humerus stâng (jumătate proximală) şi o coastă; categorie de vârstă: infans I (prin comparație dimensională cu alte oase aparținând grupei infans I);

112) M 3 / Str. Bisericii, 2006, şanț pentru alimentare cu apă pe latura vestică a străzii, zona magazinului din capătul $\mathrm{N}$ al străzii, la $\mathrm{S}$ de scara de acces, la S de M 2 - mormânt de inhumaţie; vizibil pe malurile şanţului pentru alimentarea cu apă; adâncime minimă $-0,60-0,80 \mathrm{~m}$ față de nivelul actual de călcare; orientare $\mathrm{V}-\mathrm{E}$; maxilarul vizibil pe malul $\mathrm{V}$ al şanţului; partea inferioară a scheletului pătrunde în malul E; suprapune o groapă menajeră; încadrare cronologică probabilă: epoca modernă; caracteristici antropologice: prezintă vertebre, rotulă stângă (linii puțin clare la nivelul suprafeței anterioare), metacarpiene şi metatarsiene (calcaneu stâng de dimensiuni mici); sex: probabil feminin; categorie de vârstă: adultus/adult (capete articulare sudate la corpurile vertebrale);

\section{STRADA RAPSODIEI}

113) M 1 / Str. Rapsodiei 181, 2006, şanț pentru alimentarea cu apă pe latura vestică a străzii, cpl. 01 - mormânt de inhumație; distrus la săparea mecanică a şanţului; oase umane recuperate, fără înregistrarea situației; încadrare 
cronologică probabilă: epoca modernă; caracteristici antropologice: prezintă craniu (fragmentar), mandibulă, clavicule ( $\operatorname{Lmax}=95,75$ $\mathrm{mm} / 96,49 \mathrm{~mm}$ ), scapule (distruse), humerus stâng $($ Lmax $=204,97 \mathrm{~mm})$, radius stâng (jumătate proximală), ulnă stângă (lipsă treime distală), ulnă dreaptă (jumătate proximală), vertebre, coaste, stern (manubriu), coxal drept (ischion), femur stâng (lipsă epifiză proximală), femur drept $(\operatorname{Lmax}=274,53 \mathrm{~mm})$, tibie stângă $(\operatorname{Lmax}=216,22 \mathrm{~mm})$, tibie dreaptă (lipsă epifiză distală), fibulă stângă (treime proximală), fibulă dreaptă (lipsă treime distală) şi metatarsiene; vârstă: cca. 7-9 ani, infans II (superior şi inferior: caninii şi premolarii2 în curs de ieşire, molarii 1 ieşiți, molarii 2 în alveole), cca. 5,5-8,5 ani, infans I/infans II (după lungimile maxime ale oaselor lungi); talie: cca. 133,25-135,75 cm;

114) M2 / Str. Rapsodiei 178, 2006, şanț pentru alimentarea cu apă pe latura vestică a străzii, zona bisericii, cpl. 02 - mormânt de inhumație; distrus la săparea mecanică a şanțului; oase umane recuperate, fără înregistrarea situației; încadrare cronologică probabilă: epoca modernă; caracteristici antropologice: prezintă radius stâng (jumătate distală, gracilă, subțire), radius drept (lipsă epifiză proximală), ulnă stângă (epifiză distală, jumătate proximală), ulnă dreaptă (epifiză distală), vertebre, coaste, sacrum (larg, scurt, puțin arcuit), coxal stâng (lipsă pubis, şanț sciatic grad -1), femur drept (jumătate proximală), metatarsiene şi falange; sex: feminin; vârstă: puțin peste 19 ani, juvenis/adultus (epifiză distală radială dreaptă proaspăt fuzionată, capete de articulare proaspăt sudate la corpurile vertebrale, creastă iliacă stângă proaspăt sudată); 114a) a mai fost identificat un femur (diafiză, groasă, linea aspera bine dezvoltată); sex: probabil masculin; categorie de vârstă: adultus/adult (os de dimensiuni relativ mari);

115) M 3 / Str. Rapsodiei 178, 2006, curtea bisericii - mormânt de inhumație; distrus la săparea bazinului vidanjabil; schelet recuperat fără înregistrarea situației; încadrare cronologică probabilă: epoca modernă; caracteristici antropologice: prezintă clavicule ( $\operatorname{Lmax}=147,89$ mm/ 151,66 mm), scapulă dreaptă (lipsă porțiuni din corp), humerus stâng ( $\operatorname{Lmax}=304,16 \mathrm{~mm}$, faza II), humerus drept (lipsă epifiză distală), radius stâng (spart, fragmentar), radius drept (treime proximală), ulne $(\operatorname{Lmax}=265,23 \mathrm{~mm} /$ $266,47 \mathrm{~mm}$ ), vertebre, coaste, sacrum (spart), coxal stâng (lipsă pubis, de dimensiuni mari, şanț sciatic grad +1 ), coxal drept (fragmente de ilion şi ischion), femur stâng (lipsă epifize) şi femur drept (lipsă epifiză distală, faza II); sex: masculin; vârstă: cca. 47,5 ani, maturus II; talie: cca. 157,28 $\mathrm{cm}$, mică; elemente de patologie: exostoze la nivelul extremității laterale claviculare drepte;

116) M / Str. Rapsodiei 177, 2006, cpl. 23 - mormânt de inhumație, vizibil pe malul V al şanțului pentru alimentare cu apă de pe latura vestică a străzii; adâncime minimă $-0,95 \mathrm{~m}$ față de nivelul actual de călcare; orientare probabilă V-E; L - 0,40 m; nu au fost recuperate oasele; încadrare cronologică probabilă: epoca modernă;

117) $M$ / Str. Rapsodiei 176, în dreptul proprietății Paul Schimbeschi, 2006, cpl. 31 mormânt de inhumație, vizibil pe malul $\mathrm{V}$ al şanțului pentru alimentarea cu apă de pe latura vestică a străzii; adâncime minimă $-0,40 \mathrm{~m}$ față de nivelul actual de călcare; orientare probabilă V-E; $\mathrm{L}-0,40 \mathrm{~m}$; nu au fost recuperate oasele; încadrare cronologică probabilă: epoca modernă;

118) M / Str. Rapsodiei 176, în dreptul proprietății Paul Schimbeschi, 2006, cpl. 37 mormânt de inhumație, vizibil pe malul $\mathrm{V}$ al şanțului pentru alimentarea cu apă de pe latura vestică a străzii; adâncime minimă $-0,60 \mathrm{~m}$ față de nivelul actual de călcare; orientare probabilă V-E; câteva oase vizibile pe profil, nerecuperate; încadrare cronologică probabilă: epoca modernă;

119) M 4 / Str. Rapsodiei 171, proprietatea Everina Coman, 2006, şanț pentru alimentarea cu apă a gospodăriei, mormânt de inhumaţie distrus la săparea şanțului - oase umane recuperate fără înregistrarea situației; încadrare cronologică probabilă: epoca modernă; caracteristici antropologice: prezintă craniu (glabelă grad 0, relief relativ şters, diametru antero-posterior maxim $177,57 \mathrm{~mm}$, diametru transversal maxim de 134,42 $\mathrm{mm}$, indice cranian orizontal 75,69 mezocran), mandibulă (unghiuri mandibulare grad +1 , menton grad +2); sex: incert; categorie de vârstă: adult (uzură dentară puternică, de la incisivi la molari);

120) $M$ / Str. Rapsodiei 171, în dreptul proprietăţii Everina Coman, 2006 - oase umane recuperate, fără context arheologic; încadrare cronologică probabilă: epoca modernă; caracteristici antropologice: resturi osteologice ce provin de la doi indivizi: 1) prezintă femur drept (jumătate distală), tibie stângă $(\operatorname{Lmax}=243,21$ 
mm), tibie dreaptă $($ Lmax $=245,80 \mathrm{~mm})$; vârstă: cca. 7,5-8,5 ani, infans II (după lungimile maxime ale oaselor lungi); 2) prezintă humerus stâng (treime proximală, faza III), femur drept (diafiză), tibie stângă (lipsă fragmente de epifiză proximală) şi fibulă dreaptă (diafiză); vârstă: cca. 57 ani, senilis I;

121) M 5 / Str. Rapsodiei 171-172, în dreptul proprietăţii Vasile Androne, 2006 şanţ pentru alimentarea cu apă de pe latura vestică a străzii, cpl. 46 - mormânt de inhumație; adâncime minimă $-0,85$ m față de nivelul actual de călcare; orientare probabilă $\mathrm{V}-\mathrm{E}$; schelet din care se pot observa pe profilul şanțului pentru alimentare cu apă falange, coaste, vertebre, un coxal în pământ cenuşiu gălbui; au fost recuperate mai multe oase umane decât cele vizibile pe mal; L - 1,20 m; încadrare cronologică probabilă: epoca modernă; caracteristici antropologice: prezintă, recuperate din malul şanţului, humerus drept (spart la nivelul treimii proximale, Lmax $=311,65 \mathrm{~mm}$, scurt, relativ gracil, epifize mici), radius stâng (lipsă treime distală), vertebre, coaste, sacrum (spart), coxal drept (un fragment de ilion), femure (fragmente diafizare), tibie stângă (lipsă epifiză distală), tibie stângă (un fragment de diafiză), tibie dreaptă (diafiză), metacarpiene şi falange; sex: feminin; vârstă: peste 20 ani, adultus /adult (epifize fuzionate); talie: cca. $157,33 \mathrm{~cm}$, supramijlocie;

122) $M /$ Str. Rapsodiei 173 , de-a lungul proprietății Enache-Odică, 2006, şanț pentru alimentarea cu apă de pe latura estică a străzii, cpl. 57 - mormânt de inhumaţie; adâncime minimă $-0,50 \mathrm{~m}$ față de nivelul actual de călcare; orientare probabilă V-E; schelet din care se poate observa pe profilul vestic al şanţului pentru alimentare cu apă craniul, în pământ galben; nu au fost recuperate oasele; încadrare cronologică probabilă: epoca modernă;

123) $M$ / Str. Rapsodiei 173 , de-a lungul proprietății Enache-Odică, 2006, şanț pentru alimentarea cu apă de pe latura estică a străzii, cpl. 58 - mormânt de inhumație; adâncime minimă $-0,60-0,85 \mathrm{~m}$ față de nivelul actual de călcare; orientare probabilă V-E; schelet din care se pot observa pe profilul vestic al şanţului pentru alimentare cu apă un coxal şi un femur în pământ galben; au fost recuperate mai multe oase umane decât cele vizibile pe mal; $\mathrm{L}-0,50 \mathrm{~cm}$; încadrare cronologică probabilă: epoca modernă; caracteristici antropologice: resturi osteologice recuperate ce provin de la doi indivizi: 1) prezintă craniu (occipital foarte ascuțit la nivelul inionului, oase wormiene mari, sub $\lambda$ ), humerus stâng (două fragmente de diafiză, fără conexiune), humerus drept (lipsă epifiză proximală), radius drept $($ Lmax $=251,32 \mathrm{~mm})$, vertebre (două), coaste (câteva), stern, sacrum, coxal stâng (lipsă pubis, şanţ sciatic grad +1), femur stâng (lipsă cap femural), femur drept $(\operatorname{Lmax}=438,50 \mathrm{~mm}$, faza I), tibie stângă (treime proximală şi fragmente diafizare), tibie dreaptă (treime proximală); sex: masculin; vârstă: cca. 33 ani, maturus I; talie: cca. $164,15 \mathrm{~cm}$, mijlocie; 2) prezintă femure (lipsă treimi proximale), tibii (treimi proximale), rotulă stângă, fibulă dreaptă (epifiză distală şi un fragment de diafiză); sex: feminin (oase gracile, subțiri); vârstă: peste 17 ani, adultus/adult (epifize fuzionate);

124) $M$ / Str. Rapsodiei 173 , de-a lungul proprietății Enache-Odică, 2006, şanț pentru alimentarea cu apă de pe latura estică a străzii, cpl. 59 - mormânt de inhumație; adâncime minimă $-0,90 \mathrm{~m}$ față de nivelul actual de călcare; orientare probabilă V-E; schelet din care se poate observa un femur pe profilul vestic al şanţului pentru alimentare cu apă, în pământ galben; nu a fost recuperat osul; încadrare cronologică probabilă: epoca modernă;

125) $M$ / Str. Rapsodiei 173 , de-a lungul proprietăţii Enache-Odică, 2002, pe latura estică $a$ străzii - mormânt de inhumație; adâncime minimă - la nivelul actual de călcare; orientare V-E; schelet integral conservat, cu craniul deteriorat şi coastele răvăşite, antebrațul drept pe piept, antebrațul stâng spre claviculă; cui provenind probabil de la sicriu; inventar: follis bronz, sec. XI; încadrare cronologică: epoca medio-bizantină; caracteristici antropologice: prezintă craniu (două fragmente de parietal, temporal stâng), clavicule (mari, groase, lipsă fragmente de extremităţi laterale), scapule (fragmente ce cuprind cavitățile glenoide), diafiză humerală stângă (groasă), humerus drept (lipsă epifiză distală, faza II), radius stâng (epifiză distală), radius drept (lipsă epifiză proximală), ulnă stângă (lipsă treime distală), ulnă dreaptă (treime distală), vertebre, coaste, sacrum (un fragment din S1), coxale (fragmentare, şanţuri sciatice grad +1 ), femure (fragmente de diafize şi epifize distale şi 
proximale, fără conexiuni), tibie stângă (treime distală), tibie dreaptă $(\operatorname{Lmax}=386,58 \mathrm{~mm})$, rotule, fibulă stângă (lipsă epifiză distală), fibulă dreaptă (jumătate distală), metacarpiene, metatarsiene şi falange; sex: masculin; vârstă: cca. 51 ani, senilis I; talie: cca. $168,48 \mathrm{~cm}$, supramijlocie; fig. 15; 17/5-6;

126) $M$ / Strada Rapsodiei, proprietatea Şt. Mocanu, 2007 - oase umane recuperate; fără context arheologic; încadrare cronologică probabilă: epoca modernă; caracteristici antropologice: prezintă femur drept (jumătate distală) şi tibie dreaptă $(\operatorname{Lmax}=420,72 \mathrm{~mm})$; sex: masculin (oase lungi, masive, groase, bogate în detalii anatomice, multe locuri de inserție musculară, linii, gropi, epifize mari); vârstă: peste 19 ani, adultus/adult (epifize fuzionate); talie: cca. $176,62 \mathrm{~cm}$, mare;

\section{STRADA ZIMBRULUI}

127) M 1 / Str. Zimbrului 206, 2006 mormânt de inhumație; adâncime minimă $-1,30 \mathrm{~m}$ față de nivelul actual de călcare; orientare probabilă V-E, deci paralel cu axul străzii şi al şanţului săpat pe latura sudică; deranjat la săparea mecanică a şanțului în zona lombară; antebrațul stâng pe piept; au fost descoperite oasele bazinului, osul sacru şi partea superioară a femurelor; din cupa excavatorului au fost recuperate câteva fragmente dintr-un craniu şi un radius şi un cubitus fragmentare, posibil aparținând altui schelet; încadrare cronologică probabilă: epoca modernă; caracteristici antropologice: resturi osteologice ce provin de la doi indivizi: 1) prezintă craniu (câteva fragmente de calotă), hemimandibulă stângă (corp mandibular), radius stâng (Lmax $=232,32 \mathrm{~mm})$, ulnă stângă $(\operatorname{Lmax}=257,44 \mathrm{~mm})$, vertebre, coaste, sacrum, coxal drept (lipsă pubis, şanț sciatic grad +1 , gaură obturată ischio-pubiană ovalară, dispusă în sens vertical), coxal stâng (ischion), femur drept (treime proximală, faza II) şi femur stâng (epifiză proximală); sex: masculin; vârstă: cca. 44 ani, maturus II; talie: cca. 159,66 $\mathrm{cm}$, mică; elemente de patologie: carii la nivelul molarilor 1 şi 2;2) prezintă humerus stâng (un fragment de diafiză), femur stâng (diafiză) şi tibie stângă (diafiză); sex: masculin (oase de dimensiuni mari, groase); categorie de vârstă: adultus/adult (oase de dimensiuni relativ mari);
128) M 2 / Str. Zimbrului, 2006 - mormânt de inhumație; adâncime minimă $-0,70 \mathrm{~m}$ față de nivelul actual de călcare; orientare probabilă V-E, deci paralel cu axul străzii şi al şanţului săpat pe latura sudică; deranjat la săparea mecanică a şanțului; au fost recuperate craniul şi câteva părţi din schelet; încadrare cronologică probabilă: epoca modernă; caracteristici antropologice: prezintă craniu (fragmente de occipital şi parietal), vertebre, coaste, coxale (fragmentare), femur stâng (lipsă porțiuni de diafiză), femur drept (Lmax $=408,06 \mathrm{~mm}$ ), tibie stângă (lipsă porțiuni de diafiză), fibulă stângă (fragmente de diafiză), fibulă dreaptă (lipsă epifiză proximală), metatarsiene şi falange; categorie de vârstă: infans II/juvenis (epifize nefuzionate); talie: peste 170 $\mathrm{cm}$;

129) M 3 / Str. Zimbrului, 2006 - mormânt de inhumație; la circa $12 \mathrm{~m} \mathrm{~V}$ față de M 2; adâncime minimă $-0,70 \mathrm{~m}$ faţă de nivelul actual de călcare; orientare probabilă V-E, deci paralel cu axul străzii şi al şanţului săpat pe latura sudică; deranjat la săparea mecanică a şanţului; dispunere probabilă în decubit dorsal, s-au observat câteva coaste şi femurele, nerecuperate; încadrare cronologică probabilă: epoca modernă;

130) M 4 / Str. Zimbrului, 2006 - mormânt de inhumaţie; la circa $9 \mathrm{~m} \mathrm{~V}$ faţă de M 3; adâncime minimă $-0,70 \mathrm{~m}$ față de nivelul actual de călcare; orientare probabilă V-E, deci paralelă cu axul străzii şi al şanţului săpat pe latura sudică; deranjat la săparea mecanică a şanţului; au fost recuperate craniul şi câteva părți din schelet; încadrare cronologică probabilă: epoca modernă; caracteristici antropologice: prezintă craniu (spart, mastoide grad -1), mandibulă (unghiuri mandibulare grad -1 , menton grad 0), radius stâng (epifiză distală), diafiză radială (un fragment), vertebre, coaste, stern (un fragment de corp), metatarsiene şi falange; sex: probabil feminin; vârstă: peste 19 ani, adultus/adult (grad mediu de uzură dentară);

131) M 5 / Str. Zimbrului, 2006 - mormânt de inhumație; deranjat la săparea mecanică a şanțului; la circa $15 \mathrm{~m} \mathrm{~V}$ faţă de M 4; orientare probabilă V-E, deci paralel cu axul străzii şi al şanţului săpat pe latura sudică; s-au observat un coxal şi două coaste, încadrare cronologică probabilă: epoca modernă; fără ilustrație; caracteristici antropologice: prezintă o coastă şi 
coxal drept (ilion ce tinde vertical, locuri de inserție musculară proeminente, şanț sciatic grad +1 , fațetă simfizară pubică faza III); sex: masculin; vârstă: cca. 52 ani, senilis I;

132) M / punctul Râpă, 1980, S IV, c. 4, 2,25 m - mormânt de inhumație; orientare V-E, schelet în decubit dorsal; încadrare cronologică probabilă: epoca modernă; caracteristici antropologice: prezintă craniu (aproximativ complet, eminențe frontale şi parietale mari, glabelă grad -2, diametru antero-posterior 176,27 mm mijlociu, diametru transversal maxim 127,32 $\mathrm{mm}$ foarte îngust, indice cranian orizontal 72,23 dolicocran, sutură metopică, oase wormiene la nivelul punctului $\lambda$ ), claviculă stângă (lipsă treime laterală), claviculă dreaptă $(\operatorname{Lmax}=134,19 \mathrm{~mm})$, scapule (fragmente cu cavități glenoide), humerus stâng $(\operatorname{Lmax}=288,73 \mathrm{~mm})$, humerus drept (lipsă fragmente de diafiză), radius stâng (lipsă fragmente de diafiză), radius drept (Lmax = 205,34 mm), ulnă stângă (fragmentară), ulnă dreaptă $(\operatorname{Lmax}=227,52 \mathrm{~mm})$, vertebre, coaste, stern, sacrum (S1 şi S2), coxale (lipsă pubisuri, şanţuri sciatice grad -2), metacarpiene şi falange; sex: feminin; vârstă: cca. 15 ani, juvenis (treime medială claviculară dreaptă, humerus stâng distal şi primele două vertebre sacrale, singurele epifizate).

\section{STRADA AUREL VLAICU}

133) M 1 / Str. Aurel Vlaicu 315, 2006, şanț pentru alimentarea cu apă de pe latura estică a străzii - mormânt de inhumație, deranjat la săparea mecanică a şanţului; încadrare cronologică probabilă: epoca modernă; caracteristici antropologice: prezintă craniu (diametru antero-posterior maxim 178,35 mm, diametru transversal maxim 144,40 mm, indice cranian orizontal 80,96 brahicran), claviculă stângă $(\operatorname{Lmax}=112,25 \mathrm{~mm})$, scapulă stângă (cavitate glenoidă), radius stâng ( $\operatorname{Lmax}=174,43$ mm), ulnă stângă $(\operatorname{Lmax}=190,39 \mathrm{~mm})$, vertebre, coaste, sacrum (S1), coxale (distruse), femur stâng (lipsă fragmente de diafiză), femur drept (lipsă treime distală), tibii (jumătăți proximale), fibulă stângă (treime proximală), fibulă dreaptă (jumătate proximală) şi metatarsiene; vârstă: cca. 11-12 ani, infans II (superior şi inferior: molarii 2 proaspăt ieşiți, molarilor 3 li se observă coroana), cca. 7,5-9,5 ani, infans II (după lungimile maxime ale oaselor lungi); fig. 27/4;

134) M 2 / Str. Aurel Vlaicu 314, 2006, şant pentru alimentarea cu apă de pe latura estică a străzii - mormânt de inhumație; orientare V-E; deranjat la săparea mecanică a şanțului; schelet în decubit dorsal, din care au fost identificate în conexiune anatomică coloana vertebrală, antebrațul drept (aşezat pe piept), bazinul cu partea dreaptă afectată, piciorul stâng în totalitate, tibia şi peroneul drepte; L parțială în groapă - 1,35 m; fără inventar în porțiunea cercetată; încadrare cronologică probabilă: epoca modernă; caracteristici antropologice: prezintă craniu (câteva fragmente de calotă), mandibulă (corpuri din dreptul molarilor), scapulă (un fragment), humerus drept (Lmax $=325,01 \mathrm{~mm}$, relativ lung, dar subțire, faza III), radius stâng (diafiză), radius drept (jumătate proximală şi treime distală), ulnă stângă (treime proximală), ulnă dreaptă (Lmax = $260,00 \mathrm{~mm}$ ), vertebre, coaste, stern (distrus), coxale (sparte, şanț sciatic grad +1 ), femur stâng (lipsă epifiză distală, faza III), femur drept (diafiză), tibii (diafize), fibule (diafize), metacarpiene, metatarsiene şi falange; sex: masculin; vârstă: cca. 54,5 ani, senilis I; talie: cca. 163,32 cm, submijlocie; fig. 23;

\section{STRADA MIRON COSTIN}

135) $M 1$ / Str. Miron Costin 150, 2006, şanț pentru alimentarea cu apă pe latura nordică a străzii, la V de gardul casei de pe latura estică a străzii mormânt de inhumaţie; deranjat de excavator la săparea şanţului, fiind dislocate câteva piese din schelet; adâncime minimă $-0,94 \mathrm{~m}$ față de nivelul actual de călcare; orientare SV-NE; schelet posibil deranjat anterior intervenției amintite; femurul drept suprapune pe cel stâng; L surprinsă în şanț $-0,35$ m; fără inventar; încadrare cronologică probabilă: epoca modernă; caracteristici antropologice: prezintă craniu (câteva fragmente), ulnă stângă (jumătate proximală), vertebre, coaste, coxal stâng (ilion, şanț sciatic grad -2), coxal drept (un fragment de ilion), femur stâng (lipsă epifiză distală, linea aspera slab dezvoltată, faza I), femur drept (jumătate proximală), tibie stângă (treime distală), tibie dreaptă (un fragment de diafiză), fibulă stângă (jumătate proximală), fibulă dreaptă (jumătate distală), metacarpiene, metatarsiene şi falange; sex: feminin; vârstă: cca. 33 ani, maturus I; 135a) a mai fost 
identificat un femur stâng (treime distală) şi un femur drept (jumătate proximală); categorie de vârstă: infans I (prin comparație dimensională cu alte oase aparținând grupei infans I); fig. 23; 26/2;

136) M 2 / Str. Miron Costin 151, 2006, şanţ pentru alimentarea cu apă pe latura nordică a străzii, la V de gardul casei de pe latura estică a străzii, la 0,20 m S față de M 3 - mormânt de inhumație; casetă practicată în malurile $\mathrm{E}$ şi $\mathrm{V}$ ale şanţului pentru alimentarea cu apă; adâncime minimă $-0,50$ m față de nivelul actual de călcare; orientare V-E; schelet în decubit dorsal, bine conservat; craniul deteriorat, pe partea dreaptă; braţul drept dislocat în timpul săpării mormântului, antebraţul stâng pe bazin; picioarele întinse; L în groapă - 1,68 m; fără inventar; încadrare cronologică probabilă: epoca modernă; caracteristici antropologice: prezintă craniu (fragmentar), mandibulă (unghiuri mandibulare şi menton grad -1), claviculă stângă (lipsă extremitate medială), claviculă dreaptă, scapule (cavităţi glenoide şi acromioane), humerus stâng (lipsă mici porțiuni de diafiză), humerus drept (diafiză), radius stâng, ulnă stângă (lipsă treimi distale), vertebre, coaste, stern (manubriu), coxal (puternic fragmentar), femure (diafize, puternic arcuite, linea aspera bine evidențiată), tibii (diafize), fibulă stângă (Lmax = 359,75 mm), fibulă dreaptă (lipsă epifiză distală), metacarpiene, metatarsiene şi falange; sex: masculin (oase de dimensiuni mari); vârstă: cca. 21 ani, adultus (extremitate medială claviculară dreaptă şi cap humeral stâng proaspăt fuzionate, capete de articulare în curs de sudare la corpurile vertebrale); elemente de patologie: carii la nivelul molarului 1 şi molarului 2 inferiori stânga; fig. $23 ; 26 / 3$;

137) M 3 / Str. Miron Costin 151, 2006, şanț pentru alimentarea cu apă pe latura nordică a străzii, la V de gardul casei de pe latura estică a străzii, la 0,30 m distanţă spre N faţă de M 2 - mormânt de inhumație; deranjat de excavator la săparea şanțului; casetă practicată în malurile $\mathrm{E}$ şi $\mathrm{V}$ ale şanţului pentru alimentarea cu apă; adâncime minimă $-0,37$ $m$ față de nivelul actual de călcare; schelet în decubit dorsal; orientare V-E; craniul în poziție normală; antebrațul drept pe piept, antebrațul stâng pe abdomen; zona bazinului şi a capetelor femurale deranjată de excavator; picioarele întinse, cu femurele arcuite, mai mult cel drept; L în groapă $1,73 \mathrm{~m}$; fără inventar; încadrare cronologică probabilă: epoca modernă; caracteristici antropologice: prezintă craniu (glabelă grad -1, relief occipital slab pronunțat, diametru antero-posterior maxim 182,10 $\mathrm{mm}$ lung, diametru transversal maxim 142,40 mm mijlociu, indice cranian orizontal 78,19 mezocran), mandibulă (unghiuri mandibulare şi menton grad 0), claviculă stângă (lipsă extremitate laterală), claviculă dreaptă $(\operatorname{Lmax}=158,00 \mathrm{~mm})$, scapule (procese coracoide), humerusuri (Lmax = $334,93 \mathrm{~mm} / 337,16 \mathrm{~mm}$, lungi, subțiri, gracile, faza III), radiusuri $(\operatorname{Lmax}=259,39 \mathrm{~mm} / 256,57 \mathrm{~mm})$, ulnă stângă (treime proximală), ulnă dreaptă (jumătate proximală), coxal (un fragment), femur stâng (diafiză), femur drept (lipsă epifiză proximală), rotule, tibie stângă (un fragment de diafiză), tibie dreaptă (jumătate proximală), fibule (diafize), metacarpiene, metatarsiene şi falange; sex: feminin; vârstă: cca. 57 ani, senilis I; talie: cca. $164,21 \mathrm{~cm}$, mare; fig. 23; 26/3;

138) M 4 / Str. Miron Costin 152, 2006, şanț pentru alimentarea cu apă pe latura nordică a străzii, la V de gardul casei de pe latura estică a străzii mormânt de inhumație; distrus de excavator la săparea şanțului; adâncime minimă $-0,56$ m față de nivelul actual de călcare; orientare $\mathrm{V}-\mathrm{E}$; schelet în decubit dorsal, se păstrează un fragment de craniu şi o parte din schelet; deranjate din poziţia iniţială; L surprinsă în şanț - 0,22 m; fără inventar; încadrare cronologică probabilă: epoca modernă; caracteristici antropologice: prezintă craniu (câteva fragmente de calotă), mandibulă (lipsă corpuri mandibulare din dreptul molarilor şi ramuri ascendente, menton grad +1 ), claviculă dreaptă (lipsă extremitate medială), scapulă stângă (lipsă mici porțiuni de la nivelul corpului, linii cu aspect de creste), humerus stâng (diafiză), humerus drept $(\mathrm{Lmax}=359,77 \mathrm{~mm}$, faza II), vertebre şi coaste; sex: masculin; vârstă: cca. 51 ani, senilis I, talie: cca. $173,35 \mathrm{~cm}$, mare; fig. 24 ; 26/4;

139) M 5 / Str. Miron Costin 152, 2006, şanț pentru alimentarea cu apă pe latura nordică a străzii, la V de poarta mare a casei de pe latura estică a străzii, la 0,50 m distanță spre $\mathrm{N}$ față de $\mathrm{M}$ 4 - mormânt de inhumaţie; deranjat de excavator la săparea şanţului; casetă practicată în malurile E şi V ale şanțului pentru alimentarea cu apă; adâncime minimă $-0,61 \mathrm{~m}$ față de nivelul actual de călcare; orientare $\mathrm{V}-\mathrm{E}$; schelet în decubit dorsal, bine conservat, cu excepția antebrațului stâng şi a coxalului stâng, dislocate de excavator; craniul pe partea stângă; antebrațul drept întins pe lângă corp, cu palma atingând bazinul; picioarele întinse, cu femurul stâng arcuit; L în groapă - 1,57 m; fără 
inventar; încadrare cronologică probabilă: epoca modernă; caracteristici antropologice: prezintă craniu (fragmentar), mandibulă, claviculă dreaptă (extremitate medială), scapule, humerus stâng (lipsă epifiză distală), humerus drept $(\operatorname{Lmax}=$ $311,40 \mathrm{~mm}$, faza I), radius stâng (jumătate distală), ulnă dreaptă $(\operatorname{Lmax}=263,57 \mathrm{~mm})$, vertebre, coaste, stern (manubriu), sacrum, coxale (puternic fragmentare), femur stâng (Lmax = 415,82 mm, faza I), femur drept (lipsă cap femural), tibie stângă (jumătate distală), tibie dreaptă $(\operatorname{Lmax}=345,57 \mathrm{~mm})$, fibulă dreaptă (jumătate proximală), metacarpiene, metatarsiene şi falange; sex: masculin (oase groase, bogate în detalii anatomice, având multe locuri de inserție musculară, linii, gropi şi epifize mari); vârstă: cca. 33 ani, maturus I; talie: cca. $158,55 \mathrm{~cm}$, mică; 139a) au mai fost identificate un humerus stâng $(\operatorname{Lmax}=103,75 \mathrm{~mm})$ şi o coastă; vârstă: cca. $0,5-$ 1,5 ani, infans I (după lungimea maximă a humerusului); fig.24; $26 / 5$;

140) M 6 / Str. Miron Costin 152, 2006, şanț pentru alimentarea cu apă pe latura nordică a străzii, la V de gardul casei de pe latura estică a străzii, la 3,30 m distanță spre N față de M 5 mormânt de inhumație; adâncime minimă $-0,58 \mathrm{~m}$ faţă de nivelul actual de călcare; orientare V-E; deranjat de excavator la săparea şanțului; schelet în decubit dorsal, din care a fost surprinsă în şanț jumătatea superioară; craniul deteriorat, din care s-a păstrat in situ mandibula; antebrațul drept cu oasele puțin deranjate, întins pe lângă corp, antebrațul stâng, cu oasele deranjate, pe abdomen; descoperită partea superioară a bazinului; restul scheletului pătrunde în malul $\mathrm{E}$ al şanțului; $\mathrm{L}$ surprinsă în şanț $0,54 \mathrm{~m}$; fără inventar în porțiunea cercetată; încadrare cronologică probabilă: epoca modernă; caracteristici antropologice: prezintă mandibulă (lipsă ram vertical stâng, menton grad 0), clavicule $(\operatorname{Lmax}=139,01 \mathrm{~mm} / 135,95 \mathrm{~mm})$, scapule (corpuri sparte), humerus stâng (lipsă porțiuni de diafiză, faza IV), humerus drept $(\operatorname{Lmax}=304,47 \mathrm{~mm})$, radius stâng (jumătate proximală), radius drept (jumătate distală), ulnă stângă (lipsă epifiză distală), ulnă dreaptă (Lmax $=246,91 \mathrm{~mm}$ ), vertebre, coaste (fragmente), coxale (puternic fragmentare), femur drept (cap), metacarpiene şi falange; sex: feminin (oase scurte, puțin masive, subțiri, suprafață gracilă); vârstă: cca. 59 ani, senilis I, talie: cca. 154,01 cm, mijlocie; elemente de patologie: carii la nivelul premolarului 1 şi 2 dreapta; fig. 24; 26/6;

141) M 7 / Str. Miron Costin 152, 2006, şanț pentru alimentarea cu apă pe latura nordică a străzii, la V de gardul casei de pe latura estică a străzii, la 1,50 m distanță spre N față de M 6 mormânt de inhumație; adâncime minimă $-0,42 \mathrm{~m}$ față de nivelul actual de călcare; orientare V-E; deranjat de excavator la săparea şanțului; schelet în decubit dorsal, din care a fost surprins în şanț craniul deteriorat, înclinat pe partea stângă, şi partea superioară a coloanei vertebrale şi a oaselor humerus; restul scheletului pătrunde în malul $\mathrm{E}$ al şanțului; L surprinsă în şanț $-0,33$ m; fără inventar în porțiunea cercetată; încadrare cronologică probabilă: epoca modernă; caracteristici antropologice: prezintă craniu (fragmentar), mandibulă (menton grad -1$)$, clavicule (Lmax = $127,55 \mathrm{~mm} / 126,13 \mathrm{~mm}$, scurte, gracile, detalii anatomice ce se disting cu greu pe suprafaţa lor), scapule (fragmentare, de dimensiuni mici), humerusuri (diafize), vertebre şi coaste; sex: feminin; categorie de vârstă: adultus/adult (grad mediu de uzură dentară); elemente de patologie: carii la nivelul premolarului 1 inferior stânga şi molarului 2 inferior dreapta, edentație între premolarul 2 şi molarul 1 inferior stânga; fig. 24; 26/7;

142) M 8 / Str. Miron Costin 152, 2006, şanț pentru alimentarea cu apă pe latura nordică a străzii, la V de gardul casei de pe latura estică a străzii, la 1,25 m distanță spre N faţă de M 7 mormânt de inhumație; deranjat de excavator la săparea şanțului; adâncime minimă $-0,48 \mathrm{~m}$ față de nivelul actual de călcare; orientare V-E; schelet în decubit dorsal, din care au fost surprinse în şanț craniul, înclinat pe partea stângă şi partea superioară a coloanei vertebrale şi a humerus-ului stâng; restul scheletului pătrunde în malul $\mathrm{E}$ al şanţului; $\mathrm{L}$ surprinsă în şanț $-0,37 \mathrm{~m}$; fără inventar în porțiunea cercetată; încadrare cronologică probabilă: epoca modernă; caracteristici antropologice: prezintă craniu (mic, mastoide grad -1 , foramen magnum de dimensiuni reduse), mandibulă (unghiuri mandibulare şi menton grad -1), clavicule (lipsă extremităti mediale, mici, gracile), humerus stâng (lipsă mici porțiuni de diafiză, foarte gracil, faza II), ulnă stângă (epifiză distală), vertebre, coaste, stern (un fragment de corp) şi falange; sex: feminin; vârstă: cca. 51 ani, senilis I; elemente de patologie: carie la nivelul premolarului 1 inferior 
dreapta, edentaţii în dreptul molarului 1 şi 2 superior stânga şi molarului 1 şi 3 inferior dreapta; fig. 25; 26/8;

143) M 9 / Str. Miron Costin 152, 2006, şanț pentru alimentarea cu apă pe latura nordică a străzii, la V de gardul casei de pe latura estică a străzii, la 2,20 m distanță spre N faţă de M 8 mormânt de inhumație; adâncime minimă $-0,44 \mathrm{~m}$ faţă de nivelul actual de călcare; orientare V-E; deranjat de excavator la săparea şanțului; schelet în decubit dorsal, din care au fost surprinse în şanț craniul în poziție normală, şi partea superioară a coloanei vertebrale şi a oaselor humerus, restul scheletului pătrunde în malul $\mathrm{E}$ al şanțului; L surprinsă în şanț - 0,36 m; fără inventar în porțiunea cercetată; încadrare cronologică probabilă: epoca modernă; caracteristici antropologice: prezintă craniu (fragmente groase, inserții musculare proeminente în special la nivelul occipitalului, linii nucale evidente), mandibulă (menton grad 1), claviculă stângă (lipsă extremitate medială), scapule, humerus stâng (jumătate proximală, scurtă, gracilă, faza IV), humerus drept (diafiză), vertebre (câteva) şi coaste; sex: feminin; vârstă: cca. 59 ani, senilis I; elemente de patologie: edentație la nivelul molarului 2 inferior dreapta; fig. $25 ; 27 / 1$;

144) M 10 / Str. Miron Costin 152, 2006, şanț pentru alimentarea cu apă pe latura nordică a străzii, la V de gardul casei de pe latura estică a străzii, la 0,65 m distanță spre $S$ faţă de M 9, între M 8 şi M 9 - mormânt de inhumaţie; deranjat de excavator la săparea şanțului; adâncime minimă $0,59 \mathrm{~m}$ față de nivelul actual de călcare; orientare probabilă V-E; schelet probabil în decubit dorsal, din care este vizibil doar craniul, restul scheletului pătrunzând în malul estic; încadrare cronologică probabilă: epoca modernă; caracteristici antropologice: prezintă craniu (calotă craniană de dimensiuni mici, pereți cranieni subțiri, diametru transversal maxim 136,57 mm, îngust); sex: probabil feminin; categorie de vârstă: adultus/adult (grad mediu de obliterare a suturilor craniene); fig. 25;

145) M 11 / Str. Miron Costin 151, 2006, şanț pentru alimentarea cu apă pe latura nordică a străzii, la V de gardul casei de pe latura estică a străzii - mormânt de inhumație; adâncime minimă $-0,86 \mathrm{~m}$ faţă de nivelul actual de călcare; orientare probabilă V-E; deranjat de excavator la săparea şanţului; schelet în decubit dorsal, vizibil în zona bazinului, cu partea inferioară a coloanei vertebrale şi partea superioară a femurelor; L surprinsă în şanț $-0,35 \mathrm{~m}$; fără inventar în porțiunea cercetată; încadrare cronologică probabilă: epoca modernă; caracteristici antropologice: prezintă radius stâng (Lmax = 239,20 mm), ulnă dreaptă (diafiză), vertebre, coaste, sacrum, coxal stâng (de dimensiuni mari, acetabulum larg, fațetă simfizară pubică faza III), coxal drept (fragmentar), femur drept (Lmax = $441,72 \mathrm{~mm}$, linea aspera puternic dezvoltată, faza III), femur stâng (spart), rotulă stângă şi falange; sex: masculin, vârstă: cca. 52 ani, senilis I; talie: cca. 161,91 cm, submijlocie; fig. 25; 27/2

146) M 12 / Str. Miron Costin 152, 2006, şanț pentru alimentarea cu apă pe latura nordică a străzii, la $\mathrm{V}$ de poarta mare a casei de pe latura estică a străzii, la 1,40 m distanță spre $\mathrm{N}$ față de caseta $\mathrm{M}$ 5, între M 5 şi M 6 - mormânt de inhumație; adâncime minimă $-0,67 \mathrm{~m}$ față de nivelul actual de călcare; orientare probabilă $\mathrm{V}-\mathrm{E}$; schelet în decubit dorsal, vizibil în jumătatea sa superioară, inclusiv o parte din bazin, restul scheletului pătrunzând în malul $\mathrm{E}$; din craniu, care a rămas în malul $\mathrm{V}$, este vizibilă doar mandibula; schelet deranjat în zona coastelor în momentul săpării mecanice a şanțului, dar şi de rădăcinile unui salcâm; brațul drept dislocat, antebrațul stâng pe bazin; L surprinsă în şanț $-0,60 \mathrm{~m}$; făă inventar în porțiunea cercetată; încadrare cronologică probabilă: epoca modernă; caracteristici antropologice: prezintă craniu (calotă craniană, occipital cu regiune iniacă ce prezintă linii nucale dezvoltate), mandibulă (lipsă ramuri verticale, menton grad +2), claviculă stângă (jumătate distală), claviculă dreaptă ( $\operatorname{Lmax}=158,93$ $\mathrm{mm}$, lungi, groase, detalii anatomice, locuri de inserție musculară evidente), scapule (aproximativ întregi), humerus stâng ( $\operatorname{Lmax}=332,64 \mathrm{~mm}$, faza II), humerus drept (lipsă epifiză proximală), radius stâng (jumătate proximală), radius drept (treime proximală), ulne (jumătăți proximale), vertebre, coaste, sacrum (aproximativ întreg, îngust, lung), coxale (sparte, şanţuri sciatice şi unghi pubian grad +1), femure (lipsă epifize distale, faza II), metacarpiene şi falange; sex: masculin; vârstă: cca. 47,5 ani, maturus II; talie: cca. $165,52 \mathrm{~cm}$, mijlocie; elemente de patologie: carii la nivelul molarilor 1 şi 2 inferior stânga şi la nivelul molarului 1 inferior dreapta; fig. 25; 27/3;

147) M 13 / Str. Miron Costin, 2006, şant pentru alimentarea cu apă pe latura nordică a străzii 
- mormânt de inhumație; orientare probabilă V-E; deranjat de excavator la săparea şanțului pentru alimentarea cu apă - schelet probabil în decubit dorsal; oase umane recuperate; încadrare cronologică probabilă: epoca modernă; caracteristici antropologice: resturi osteologice ce provin de la doi indivizi: 1) prezintă craniu (câteva fragmente de calotă), mandibulă (unghiuri mandibulare şi menton grad 0) şi tibie stângă (epifiză distală, mică); sex: probabil feminin; categorie de vârstă: adult (grad de uzură dentară avansat); elemente de patologie: edentații la nivelul molarilor inferiori stânga şi în zona dintre premolarul 2 şi molari inferiori dreapta; 2) prezintă tibie stângă (jumătate proximală) şi tibie dreaptă (lipsă epifiză proximală); categorie de vârstă: infans I (prin comparație dimensională cu alte oase aparţinând grupei infans I);

148) M 14 / Str. Miron Costin, 2006, şanţ pentru alimentarea cu apă pe latura nordică a străzii - mormânt de inhumație; orientare V-E; schelet probabil de adult, în decubit dorsal; nerecuperat, din cauza adâncimii mari, lăsat in situ; încadrare cronologică probabilă: epoca modernă;

149) M 15 / Str. Miron Costin, 2006, şanț pentru alimentarea cu apă pe latura nordică a străzii - mormânt de inhumație; orientare probabilă V-E; deranjat de excavator la săparea şanţului pentru alimentarea cu apă; schelet probabil în decubit dorsal; oase umane recuperate; fără inventar; încadrare cronologică probabilă: epoca modernă; caracteristici antropologice: prezintă craniu (aproximativ complet, glabelă şi mastoide grad -1, pereții cranieni subțiri), mandibulă, claviculă stângă (lipsă extremitate laterală, subțire, gracilă), scapulă (un fragment de acromion), humerus drept (jumătate proximală, faza III), ulnă stângă (epifiză distală) şi coaste (câteva); sex: feminin; vârstă: cca. 57 ani, senilis I;

150) $M$ / Str. Miron Costin, 2006, şanț pentru alimentarea cu apă pe latura nordică a străzii - oase umane recuperate; încadrare cronologică probabilă: epoca modernă; caracteristici antropologice: prezintă mandibulă (lipsă ramuri verticale, menton grad -1), scapulă stângă (cavitate glenoidă şi acromion), radius drept (jumătate distală), coxal drept (un fragment de ilion), femur drept (diafiză), tibie stângă (diafiză) şi fibule (diafize); sex: feminin (elemente scheletice gracile, puțin masive, subțiri, cu suprafaţă netedă); vârstă: peste 20 ani, juvenis/adult (proces acromial fuzionat, toate oasele epifizate); elemente de patologie: edentaţie bilaterală între premolarul 2 şi molarul 2;

151) $M$ / Str. Miron Costin, 2006, şanț pentru alimentarea cu apă pe latura nordică a străzii - oase umane recuperate; încadrare cronologică probabilă: epoca modernă; caracteristici antropologice: prezintă humerusuri (jumătăți proximale, groase, puternice, faza II), ulnă stângă (epifiză distală), o apofiză spinoasă vertebrală, coaste şi femur stâng (treime proximală, faza II); sex: masculin; vârstă: cca. 47,5 ani, maturus II;

152) $M$ / Str. Miron Costin, 2006, şanț pentru alimentarea cu apă pe latura nordică a străzii - oase umane recuperate; încadrare cronologică probabilă: epoca modernă; caracteristici antropologice: prezintă claviculă stângă (lipsă extremitate laterală), scapulă dreaptă (aproximativ întreagă), humerus stâng (Lmax = 320,10 mm, faza II), humerus drept (epifiză distală), radius stâng (jumătate distală), radius drept $(L \max =242,97$ mm), ulnă dreaptă (lipsă epifiză proximală), vertebre, coaste, coxal (un fragment de ilion), femur drept (epifiză proximală), astragal stâng şi falange; sex: masculin (oase lungi de dimensiuni mari, bogate în detalii anatomice); vârstă: cca. 51 ani, senilis I; talie: cca. $162,51 \mathrm{~cm}$, submijlocie; 152a) a mai fost identificat un femur stâng (lipsă epifiză distală); categorie de vârstă: infans I (prin comparație dimensională cu alte oase aparținând grupei infans I);

153) $M$ / Str. Miron Costin, 2006, şanț pentru alimentarea cu apă pe latura nordică a străzii - oase umane recuperate; încadrare cronologică probabilă: epoca modernă; caracteristici antropologice: prezintă craniu (fragmentar), hemimandibulă stângă (corp mandibular din dreptul molarilor), humerus drept (diafiză, circumferința mare, groasă), vertebre (două), stern (manubriu) şi coxal (un fragment de ilion); sex: probabil masculin, categorie de vârstă: adultus/adult (grad mediu de uzură dentară); elemente de patologie: carie la nivelul molarului 1 superior dreapta;

154) $M$ / Str. Miron Costin, 2006, şanț pentru alimentarea cu apă pe latura nordică a străzii - oase umane recuperate; încadrare cronologică probabilă: epoca modernă; caracteristici antropologice: prezintă craniu (fragmentar), claviculă stângă (jumătate medială), scapulă stângă (fragmentară), scapulă dreaptă (aproximativ întreagă), humerus stâng (lipsă 
epifiză distală, faza III), humerus drept (lipsă epifiză proximală), radius drept (Lmax $=245,15 \mathrm{~mm})$, ulnă dreaptă (epifiza distală), vertebre, coaste, stern (corp), fibulă stângă (diafiză fibulară) şi falange; sex: masculin (oase lungi masive, groase); vârstă: cca. 57 ani, senilis I; talie: cca. 163,84 cm, submijlocie; elemente de patologie: carie la nivelul molarului 2 superior dreapta, edentație la nivelul molarului 1 superior dreapta;

155) M / Str. Miron Costin, 2006, şant pentru alimentarea cu apă pe latura nordică a străzii - oase umane recuperate; încadrare cronologică probabilă: epoca modernă; caracteristici antropologice: prezintă humerus stâng (diafiză), humerus drept (fragmente de epifiză şi diafiză distală), vertebre, coaste, femure (diafize), tibie dreaptă (lipsă epifiză proximală) şi fibulă (un fragment de diafiză); sex: feminin; vârstă: peste 16 ani, juvenis/adult (epifize fuzionate);

156) M / Str. Miron Costin, 2006, şanț pentru alimentarea cu apă pe latura nordică a străzii - oase umane recuperate; încadrare cronologică probabilă: epoca modernă; caracteristici antropologice: prezintă radiusuri (treimi proximale şi distale), ulne (treimi distale), coxale (pubisuri, fragmente de ilioane, fațete simfizare pubice faza II), femur stâng (Lmax = 395,08 mm, suprafață netedă, linea aspera slab evidențiată, cap femural de dimensiuni reduse, faza II), femur drept (cap femural şi jumătate distală) şi fibule (diafize); sex: feminin; vârstă: cca. 44 ani, maturus II, talie: cca. 148,62 cm, mică; 156a) a mai fost identificată o diafiză tibială; categorie de vârstă: infans I (prin comparație dimensională cu alte oase aparținând grupei infans I);

157) M / Str. Miron Costin, 2006, şanț pentru alimentarea cu apă pe latura nordică a străzii - oase umane recuperate; încadrare cronologică probabilă: epoca modernă; caracteristici antropologice: resturi osteologice ce provin de la cel puțin patru indivizi: prezintă craniu (calotă), scapulă dreaptă (cavitate glenoidă şi acromion), patru humerusuri (stângi, Lmax $=311,75 \mathrm{~mm}$, faza III şi $\operatorname{Lmax}=180,49 \mathrm{~mm}$ ), radius stâng (epifiză proximală), radius drept (lipsă epifiză distală), ulne, o vertebră lombară, coaste (câteva fragmente), femur (cap şi diafiză); sexe: feminin şi probabil feminin (după lungimile maxime şi morfologia oaselor lungi); vârste şi categorii de vârstă: cca. 57 ani, senilis I, cca 20 ani, adultus (epifiză proximală humerală dreaptă proaspăt fuzionată), cca. 5,5-6,5 ani, infans I şi infans I (prin comparație dimensională cu alte oase aparținând grupei infans I); talie: cca. 156,01 cm (pentru senilis I), supramijlocie;

\section{STRADA TRANDAFIRILOR}

158) M 1 / Str. Trandafirilor, în dreptul proprietăţii D. Popa, 2006, şanț pentru alimentarea cu apă pe latura ... a străzii, spre intersecția cu str. Teilor - mormânt de inhumație; orientare probabilă V-E, deci paralelă cu axul şanțului; deranjat de excavator la săparea şanțului pentru alimentarea cu apă; schelet probabil în decubit dorsal; oase umane recuperate; încadrare cronologică probabilă: epoca modernă; caracteristici antropologice: prezintă craniu (fragmentar), mandibulă (aproximativ întreagă, unghiuri mandibulare grad -1 , menton grad -2 ), claviculă stângă (lipsă extremitate laterală, subțire, gracilă), claviculă dreaptă (lipsă extremitate medială), humerus stâng (jumătate distală), humerus drept (cap), ulnă dreaptă (jumătate proximală, subțire), vertebre (câteva) şi coaste; sex: feminin; categorie de vârstă: adult (grad ridicat de uzură dentară); elemente de patologie: carii la nivelul molarilor 3 inferiori;

159) M 2 / Str. Trandafirilor, în dreptul proprietăţii D. Popa, 2006, şanț pentru alimentarea cu apă pe latura ... a străzii, spre intersecția cu str. Teilor - mormânt de inhumație; orientare probabilă V-E, deci paralelă cu axul şanţului; deranjat de excavator la săparea şanţului pentru alimentarea cu apă; schelet probabil în decubit dorsal; oase umane recuperate; încadrare cronologică probabilă: epoca modernă; caracteristici antropologice: prezintă coxal (fragmente de ilion), femur (treime inferioară diafizară) şi metatarsiene; categorie de vârstă: juvenis/adult (oase de dimensiuni relativ mari);

160) M 3 / Str. Trandafirilor, în dreptul proprietății V. Gheorghe, spre intersecția cu str. Miron Costin, 2006, şanţ pentru alimentarea cu apă pe latura sudică a străzii - mormânt de inhumație; orientare probabilă V-E, deci paralelă cu axul şanţului; deranjat de excavator la săparea şanțului pentru alimentarea cu apă; schelet probabil în decubit dorsal; oase umane recuperate; încadrare cronologică probabilă: epoca modernă; 
caracteristici antropologice: prezintă claviculă stângă $(\operatorname{Lmax}=123,17 \mathrm{~mm})$, humerus stâng $(\operatorname{Lmax}=270,42 \mathrm{~mm})$, radius drept $(\operatorname{Lmax}=$ 205,05 mm), ulnă stângă (jumătate distală), vertebre (câteva) şi coaste; sex: feminin (oase subțiri, suprafață gracilă); vârstă: cca. 20 ani, adultus (epifiză proximală humerală stângă, epifize proximale şi distale radiale şi epifiză distală ulnară stângă, proaspăt fuzionate); talie: cca. 146,17 cm, mică;

161) M 4 / Str. Trandafirilor, în dreptul proprietății V. Gheorghe, spre intersecția cu str. Miron Costin, 2006, şanț pentru alimentarea cu apă pe latura sudică a străzii - mormânt de inhumație; orientare probabilă V-E, deci paralelă cu axul şanţului; deranjat de excavator la săparea şanțului pentru alimentarea cu apă; schelet probabil în decubit dorsal; oase umane recuperate; încadrare cronologică probabilă: epoca modernă; caracteristici antropologice: prezintă craniu (maxilar), mandibulă (unghiuri mandibulare şi menton grad -1$)$, claviculă stângă $(\operatorname{Lmax}=133,88$ mm, scurtă, gracilă), claviculă dreaptă (lipsă extremitate medială), scapulă stângă (fragmentară), humerus drept (cap şi un fragment de diafiză), vertebre şi coaste (câteva); sex: feminin; categorie de vârstă: adultus/adult (grad redus de uzură dentară, extremitate medială claviculară stângă epifizată);

162) M 5 / Str. Trandafirilor, în dreptul proprietății V. Baciu, spre intersecția cu str. Miron Costin, 2006, şanț pentru alimentarea cu apă pe latura sudică a străzii - mormânt de inhumație; orientare probabilă V-E, deci paralelă cu axul şanţului; deranjat de excavator la săparea şanțului pentru alimentarea cu apă; schelet probabil în decubit dorsal; oase umane recuperate; încadrare cronologică probabilă: epoca modernă; caracteristici antropologice: prezintă vertebre (câteva), femur stâng (diafiză), tibie stângă (treime proximală), fibule (diafize, fragmentare) şi metatarsiene; sex: feminin (oase scurte, suprafață netedă, gracilă), vârstă: peste 17 ani, juvenis/adult (epifize fuzionate).

\section{BIBLIOGRAFIE (PENTRU STUDIUL ARHEOLOGIC)}

Angelova 1995 - Stefka Angelova, Srednovekoven nekropol kraj juznata stena na Drăstăr (Silistra), Godişnik, 86, 1993, p. 59-143;

Angelova et alii 2002 - Stefka Angelova, Rumiana Koleva, V. Pencev, Archeologhiceskite proucivanija v natzionalnija archeologhiceski i architekturen rezervat „Durostorum-Drăstăr-Silistra”, Godişnik, 2002, p. 271-280;

Angelova et alii 2005 - Stefka Angelova, G. Atanasov, Rumiana Koleva, Archeologhiceski razkopki v natzionalnija architekturno-archeologhiceski rezervat „Durostorum-Drăstăr-Silistra” prez 1993 g., Godişnik, 1, 2005, p. 188-192;

Baraschi 1977 - Silvia Baraschi, Observații asupra necropolelor din epoca feudală timpurie din Dobrogea, SCIVA, 28, 1977, 3, p. 403-417;

Baraschi, Moghior 1979 - Silvia Baraschi, N. Moghior, N., Sondajele de la Nufãru - Ilganii de Jos (jud. Tulcea), SMMIM, 12, 1979, p. 186-191;

Baraschi, Moghior 1980 - Silvia Baraschi, N. Moghior, Cercetările arheologice de la Nufăru Ilgani (1979), SMMIM, 13, 1980, p. 123-134;

Baraschi, Moghior 1983 - Silvia Baraschi, N. Moghior, Săpăturile de salvare de la Nufăru (1981), SMMIM, 16, 1983, p. 134-139;

Baraschi, Moghior 1984-1985 - Silvia Baraschi, N. Moghior, Date noi referitoare la fortificațiile medieval-timpurii din complexul arheologic de la Nufăru - Ilgani, județul Tulcea, SMMIM, 17-18, 1984-1985, p. 144-151;

Barnea 1961 - I. Barnea, Garvăn-Dinogetia, Bucureşti, 1961;

Barnea 1973 - I. Barnea, Noi descoperiri din epoca feudalismului timpuriu la Dinogetia-Garvăn, jud. Tulcea (1963-1968), MCA, 10, 1973, p. 291-331;

Barnea 1987 - I. Barnea, Monumente creştine şi viața bisericească în secolele VII-XIV pe teritoriul Dobrogei, în Monumente istorice şi izvoare creştine, Galați, 1987; 
Barnea, Barnea 1984 - I. Barnea, Al. Barnea, Săpăturile de salvare de la Noviodunum, Peuce, 9, 1984, p. 97-105;

Barnea, Ştefănescu 1971 - I. Barnea, Şt. Ştefănescu, Din istoria Dobrogei. Bizantini, români şi bulgari la Dunărea de Jos, vol. III, Bucureşti, 1971;

Barnea et alii 2002 - Al. Barnea, D. Paraschiv, A. Stănică, Ostrov, com. Ostrov, jud. Tulcea [Beroe], în CCA, campania 2001, Buziaş, 2002, p. 225-226, nr. 120;

Baumann et alii 1998 - V. H. Baumann, Gh. Mănucu-Adameşteanu, Mihaela Iacob, D. Paraschiv, S. Mănăstireanu, Isaccea, jud. Tulcea. I. Noviodunum, în CCA, campaniile 1995-1997, Călăraşi, 1998, p. 34 35, nr. 41;

Baumann et alii 2003 - V. H. Baumann, A. Stănică, Gh. Mănucu-Adameşteanu, Ch. Lockyear, C. Olariu, D. Aparaschivei, Isaccea, jud. Tulcea. [Noviodunum], în CCA, campania 2002, p. 156-157, nr. 101;

Baumann et alii 2004 - V. H. Baumann, A. Stănică, Gh. Mănucu-Adameşteanu, C. Olariu, Luminița Bejenaru, Ch. Lockyear, A. Popescu, T. Sly, Isaccea, jud. Tulcea. [Noviodunum], în CCA, campania 2003, p. 146-149, nr. 91;

Baumann et alii 2006 - V. H. Baumann, A. Stănică, Gh. Mănucu-Adameşteanu, C. Olariu, Luminița Bejenaru, Ch. Lockyear, A. Popescu, T. Sly, Isaccea, jud. Tulcea [Noviodunum], în CCA, campania 2005, Constanța, 2006, p. 181-187, nr. 96;

Bătrîna, Bătrîna 1977 - Lia Bătrîna, A. Bătrîna, Contribuții la cunoaşterea arhitecturii medievale din Dobrogea: biserica Sf. Atanasie din Niculițel (jud. Tulcea), SCIVA, 28, 1977, 4, p. 531-552;

Bârzu 1973 - Ligia Bârzu, Continuitatea populației autohtone în Transilvania în secolele IV-V (Cimitirul 1 de la Bratei), Bucureşti, 1973;

Bobceva 1978 - Ljubka Bobceva, Nekropol ot XIII-XIV vek v Kaliakra, IzvestijaVarna, 14 (29), 1978, p. 152-180;

Bobceva 1984 - Ljubka Bobceva, Starobălgarski christianski nekropol pri s. Krăgulevo, Tolbuchinski okrag, IzvestijaVarna, 20 (35), 1984, p. 53-58;

Bobceva, Salkin 1973 - Ljubka Bobceva, A. Salkin, Srednovekoven nekropol v s. Bălgarevo, IzvestijaTolbuchin, 1, 1973, p. 173-175;

Botov 1977 - K. Botov, Starobălgarski nekropol krai s. Chitovo, Tolbuchinsko, IzvestijaVarna, 13 (28), 1977, p. 177-183;

Chera-Mărgineanu 1981 - C-tin. Chera-Mărgineanu, Morminte creştine timpurii descoperite la Ostrov, Pontica, 14, 1981, p. 297-303;

Chera-Mărgineanu, Lungu 1983 - C-tin. Chera-Mărgineanu, V. Lungu, Contribuții la cunoaşterea unor necropole creştine ale Tomis-ului (II), Pontica, 16, 1983, p. 217-230;

Ciolakov 1995 - S. Ciolakov, Antropologicino proucivane na srednovekoven necropol ot Drăstăr, 86, 1993, Sofia, 1995, p. 105-121;

Comşa 1962 - E. Comşa, Săpături arheologice la Luncavița, MCA, 8, 1962, p. 221-225;

Condurachi et alii 1961 - E. Condurachi şi colaboratorii, Şantierul arheologic Histria, MCA, 7, 1961, p. 227-271;

Custurea 1986 - G. Custurea, Cercetările arheologice din necropola aşezării medievale Ester-Târguşor, MCA (a XVI-a Sesiune anuală de rapoarte, Vaslui, 1982), Bucureşti, 1986, p. 300-304;

Damian 1993 - Oana Damian, O necropolă medievală timpurie descoperită la Nufăru, jud. Tulcea, SCIVA, 44, 1993, 1, p. 80-113;

Damian, Bănăseanu 2006 - Oana Damian, Anca Bănăseanu, Ostrov, com. Ostrov, jud. Constanța, Punct: Păcuiul lui Soare, în CCA, campania 2005, Constanța, 2006, p. 237-240, nr. 131;

Damian et alii 2000 - Oana Damian, C. Andonie, M. Vasile, Nufăru, jud. Tulcea, în CCA, campania 1999, Deva, 2000, p. 67-68, nr. 94;

Damian et alii 2001 - Oana Damian, C. Andonie, M. Vasile, Nufăru, jud. Tulcea, în CCA, campania 2000, Suceava, 2001, p. 164-165, nr. 134;

Damian et alii 2002 - Oana Damian, C. Andonie, A. Stănică, M. Vasile, Nufăru, jud. Tulcea, în CCA, campania 2001, Buziaş, 2002, p. 216-218, nr. 151;

Damian et alii 2003a - Oana Damian, C. Andonie, M. Vasile, Nufăru - despre problemele unui sit 
arheologic suprapus de o aşezare contemporană, Peuce, S.N. 1 (14), 2003, p. 237-266;

Damian et alii 2003b - Oana Damian, C. Andonie, P. Damian, M. Vasile, A. Stănică, Christina Ştirbulescu, Nufăru, jud. Tulcea, în CCA, campania 2002, Covasna, 2003, p. 213-216, nr. 128;

Damian et alii 2005 - Oana Damian, M. Vasile, A. Stănică, Andra Samson, Nufăru, jud. Tulcea, în CCA, campania 2004, Mangalia, 2005, p. 245-246, nr. 156;

Damian et alii 2006 - Oana Damian, M. Vasile, A. Stănică, Anca Bănăseanu, Andra Samson, Nufăru, jud. Tulcea, în CCA, campania 2005, Constanţa, 2006, p. 237-240, nr. 124;

Damian et alii 2007a - Oana Damian, M. Vasile, A. Stănică, Anca Bănăseanu, Andra Samson, Cercetări arheologice preventive la Nufăru, jud. Tulcea, MCA, SN, 3, 2007, sub tipar;

Damian et alii 2007b - Oana Damian, M. Vasile, A. Stănică, Anca Bănăseanu, Andra Samson, Nufăru, jud. Tulcea, în CCA, campania 2006, Tulcea, 2007, p. 242-243, nr. 126;

Diaconu 1963a - P. Diaconu, Un mormânt din sec. XI descoperit la Dervent, SCIV, 14, 1963, 1, p. 213216;

Diaconu 1963b - P. Diaconu, Urme vechi creştine descoperite în sud-vestul Dobrogei, Biserica Ortodoxă Română, 5-6, 1963, p. 546-557;

Diaconu 1964 - P. Diaconu, Un cimitir din secolul al IV-lea descoperit la Mangalia, Glasul Bisericii, 22, 1964, 7-8, p. 712-723;

Diaconu 1993 - P. Diaconu, Sur les nécropoles danubiennes (VI - $X^{e}$ siècles), Dacia, NS, 37, 1993, p. 291-300;

Diaconu, Anghelescu 1968 - P. Diaconu, N. Anghelescu, Urme vechi de locuire în colțul de sud-vest al Dobrogei, Revista Muzeelor, 5, 1968, p. 348-351;

Diaconu, Baraschi 1977 — P. Diaconu, Silvia Baraschi, Păcuiul lui Soare, II, Aşezarea medievală (secolele XIII-XV), Bucureşti, 1977;

Diaconu, Damian 1995 - P. Diaconu, Oana Damian, Păcuiul lui Soare, jud. Constanța, în CCA, campania 1994, Cluj, 1995, p. 67, nr. 93;

Diaconu, Damian 1996 - P. Diaconu, Oana Damian, Păcuiul lui Soare, jud. Constanța, în CCA, campania 1995, Brăila, 1996, p. 87, nr. 103;

Diaconu, Damian 1997 - P. Diaconu, Oana Damian, Păcuiul lui Soare-Dervent, jud. Constanţa, în CCA, campania 1996, Bucureşti, 1997, p. 43-44, nr. 75;

Diaconu, Vîlceanu 1972 - P. Diaconu, D. Vîlceanu, Păcuiul lui Soare, I, Aşezarea bizantină, Bucureşti; 1972;

Diaconu et alii 1997 - P. Diaconu, Silvia Baraschi, T. Papasima, A. Panaitescu, V. Sârbu, D. Căpăţână, Oana Damian, Păcuiul lui Soare, jud. Constanța, în CCA, campaniile 1983-1992, Bucureşti, 1997, p. 6668, nr. 47;

Diaconu et alii 2003 - P. Diaconu, Oana Damian, Monica Mărgineanu Cârstoiu, V. Apostol, Şt. Bâlici, Ostrov, com. Ostrov, jud. Constanța, Punct: Păcuiul lui Soare, în CCA, campania 2002, Covasna, 2003, p. 223-224, nr. 137;

Diaconu et alii 2005 - P. Diaconu, Oana Damian, Anca Bănăseanu, Monica Mărgineanu Cârstoiu, Şt. Bâlici, Ostrov, com. Ostrov, jud. Constanța, Punct: Păcuiul lui Soare, în CCA, campania 2004, Mangalia, 2005, p. 251-252, nr. 161;

Donceva-Petkova 1993 - Liudmila Donceva-Petkova, Srednovekoven nekropol pri selo Odărtzi, Dobricko (Predvaritelno saobsenie), Dobrudja, 10, 1993, p. 134-144;

Donceva-Petkova 1998 - Liudmila Donceva-Petkova, Adornments from a $11^{\text {th }}$ Century Pechenegs' Necropolis by Odartsi Village, Dobrich district (north-eastern Bulgaria), Archaeologia Bulgarica, II, 1998, 3, p. 126-138;

Donceva-Petkova 1999 — Liudmila Donceva-Petkova, Odărtzi. Selişte ot Părvoto bălgarsko tzarstvo, Tom 1, Sofia; 1999;

Donceva-Petkova et alii 1989 - Liudmila Donceva-Petkova, Stefka Angelova, V. Jotov, Rannosrednovekovniat nekropol pri s. Topola, Tolbucinski okrăg, în Problemi na prabălgarskata istorija $i$ kultura, Sofia, 1989, p. 187-197;

Fiedler 1992 - U. Fiedler, Studien zu Graberfeldern des 6 bis. 9 Jahrhunderts an der unteren Donau, Bonn, 
1992;

Florescu et alii 1961 - Gr. Florescu, R. Florescu, Gloria Ceacalopol, Săpăturile arheologice de la Capidava, MCA, 7, 1961, p. 571-581;

Florescu et alii 1962 - Gr. Florescu, R. Florescu, Gloria Ceacalopol, Săpăturile arheologice de la Capidava, MCA, 8, 1962, p. 693-704;

Georgiev et alii 1969 - G. I. Georgiev, T. Ivanov, St. Mihajlov, Résultats des fouilles archéologiques effectuées en Bulgarie en 1965, Bulletin d'Archéologie sud-est européenne, 1, 1969, p. 35-59;

Hamparțumian 1971 - N. Hamparțumian, Contribuții la topografia cetății Histria în epoca romanobizantină. Considerații generale asupra necropolei din sectorul bazilicii ,extra muros”, SCIV, 22, 1971, 2, p. 199-216;

Iacob et alii 2007 - Mihaela Iacob, D. Paraschiv, G. Nuţu, Enisala, com. Sarichioi, jud. Tulcea, punctul La Peşteră, CCA, campania 2006, p. 146-147, nr. 76;

Irimia 1981 - M. Irimia, Observații preliminare privind aşezarea antică de la Gura Canliei, Pontica, 14, 1981, p. 67-122;

Irimia 1982 - M. Irimia, Un mormânt de epocă medievală descoperit la Gura Canliei, jud. Constanța, SCIVA, 33, 1982, 1, p. 140-143;

Irimia, Cliante 1986 - M. Irimia, Tr. Cliante, Morminte din epoca feudală timpurie descoperite în punctul Sitorman (com. M. Kogălniceanu, jud. Constanța), Pontica, 19, 1986, p. 179-190;

Jugănaru et alii 2004 - G. Jugănaru, S. Ailincăi, A. Stănică, Enisala, com. Sarichioi, jud. Tulcea, punctul Palanca, CCA, campania 2003, p. 118-119, nr. 71;

Jugănaru et alii 2005 - G. Jugănaru, S. Ailincăi, Enisala, com. Sarichioi, jud. Tulcea, punctul Palanca, CCA, campania 2004, p. 144-145, nr. 92;

Jugănaru et alii 2006 - G. Jugănaru, S. Ailincăi, Alexandra Țârlea, Mirela Vernescu, Enisala, com. Sarichioi, jud. Tulcea, punctul Palanca, CCA, campania 2005, p. 153-154, nr. 72;

Jugănaru et alii 2007 - G. Jugănaru, S. Ailincăi, Alexandra Țârlea, Mirela Vernescu, Enisala, com. Sarichioi, jud. Tulcea, punctul Palanca, CCA, campania 2006, p. 145-146, nr. 73;

Lăzurcă, Mănucu-Adameşteanu 1980 - Elena Lăzurcă, Gh. Mănucu-Adameşteanu, Noi descoperiri arheologice la Enisala, județul Tulcea, MCA, a XIV-a sesiune anuală de rapoarte, Tulcea, 1980, p. 146-156;

Lungu, Chera-Mărgineanu 1982 - V. Lungu, C-tin. Chera-Mărgineanu, Contribuţii la cunoaşterea unei necropole creştine a Tomis-ului, Pontica 15, 1982, p. 175-199;

Lungu, Mănucu-Adameşteanu 1995 - Vaslica Lungu, Gh. Mănucu-Adameşteanu, Săpături arheologice de salvare pe teritoriul comunei Sarichioi (jud. Tulcea), Peuce, 11, 1995, p. 339-362;

Mănucu-Adameşteanu 1983 - Gh. Mănucu-Adameşteanu, Cercetările arheologice efectuate în com. Nufăru (jud. Tulcea), MCA (a XV-a Sesiune anuală de rapoarte, Braşov, 1981), Bucureşti, 1983, p. 470-473;

Mănucu-Adameşteanu 1984a - Gh. Mănucu-Adameşteanu, Din nou despre vasele sferoconice în lumina descoperirilor din nordul Dobrogei, Peuce, 9, 1984, p. 363-374;

Mănucu-Adameşteanu 1984b - Gh. Mănucu-Adameşteanu, Descoperiri mărunte de la Isaccea (sec. X$X I V)$, Peuce, 9, 1984, p. 237-255;

Mănucu-Adameşteanu 1984c - Gh. Mănucu-Adameşteanu, Aspecte ale ritului şi ritualului în lumina descoperirilor din necropola medievală de la Enisala, Peuce, 9, 1984, p. 355-362;

Mănucu-Adameşteanu 1991a - Gh. Mănucu-Adameşteanu, Circulația monetară la Nufăru în secolele $X-X I V$, Peuce, 10, 1991, p. 497-554;

Mănucu-Adameşteanu 1991b - Gh. Mănucu-Adameşteanu, Tomis-Constantia-Constanța, Pontica, 24, 1991, p. 299-327;

Mănucu-Adameşteanu 1991c - Gh. Mănucu-Adameşteanu, Un mormânt din secolul X descoperit la Niculițel, Peuce, 10, 1991, p. 361-364;

Mănucu-Adameşteanu 1998 - Gh. Mănucu-Adameşteanu, Nufăru (jud. Tulcea) - oraş bizantin fortificat la Dunărea de Jos (sec. X-XIII), Arheologia Medievală, 2, 1998, p. 79-86;

Mănucu-Adameşteanu, Mănucu-Adameşteanu 1986 - Gh. Mănucu-Adameşteanu, Mihaela MănucuAdameşteanu, Rezultatele cercetărilor întreprinse la Nufăru, MCA (a XVI-a Sesiune anuală de rapoarte, Vaslui, 1982), Bucureşti, 1986, p. 211-214; 
Mănucu-Adameşteanu et alii 2007 - Gh. Mănucu-Adameşteanu, Oana Damian, Delia Moisil, Mihaela Iacob, E. Petac, Descoperiri romane şi romano-bizantine la Nufăru, Peuce, SN, 3-4, 2007, p. 375-398;

Melamed 1987 - Katja Melamed, Sur la population du Haut Moyen Age, habitant le site près du village Durankulak, département de Tolbuhin, în Dobrudza. Etudes ethno-culturelles, Sofia, 1987, p. 83-92;

Melamed 1989 - Katja Melamed, Srednovekovnite nekropoli, în Durankulak, I, Sofia, 1989;

Michailov 1971 - St. Michailov, Fouilles de sites du Moyen Age, în Bulgarie, Bulletin d'Archéologie sud-est européenne, 2, 1971, p. 47-58;

Micu et alii 2006 - C. Micu, F. Mihail, A. Stănică, S. Ailincăi, M. Maille, Mădălina Ungureanu, Luncavița, com. Luncavița, jud. Tulcea, în CCA, Campania 2005, Constanța, 2006, p. 209-210, nr. 104;

Mircev 1961 - M. Mircev, Novootkrit srednovekoven nekropol pri Cavarna, Izvestija-Varna, 12, 1961, p. 67-76;

Panaitescu 1983 - A. Panaitescu, Un mormânt din epoca prefeudală de la Adamclisi, Hierasus, 5, 1983, p. 157-160;

Paraschiv, Nuțu 2007 - D. Paraschiv, G. Nuțu, Tulcea, jud. Tulcea [Aegyssus], punct: Dealul Monumentului, în CCA, campania 2006, Tulcea, 2007, p. 383;

Petre 1962 - A. Petre, Săpăturile de la Piatra-Frecăței, MCA, 8, 1962, p. 565-586;

Petre 1987 - A. Petre, La romanité en Scythie Mineure (II $-V I I^{e}$ siècles de notre ère). Recherches archéologiques, Bucarest, 1987;

Popa 1964 - R. Popa, Păcuiul lui Soare. O aşezare dunăreană cu trăsături urbane în veacurile XIII-XIV, Studii, 1, 1964, p. 107-115;

Preda 1980 - C-tin. Preda, Callatis. Necropola romano-bizantină, Bucureşti, 1980;

Simion 1971 - G. Simion, Necropola feudal-timpurie de la Nalbant, Peuce, 2, 1971, p. 221-248;

Stănică 2004 - A. Stănică, Câteva aspecte privind aşezarea medio-bizantină de la Ostrov - Piatra Frecăței (Beroe), jud. Tulcea, în Prinos lui Petre Diaconu la 80 de ani, Brăila, 2004, p. 357-366;

Stănică et alii 2005-2006 - A. Stănică, S. Ailincăi, Adina Ignat, Iuliana Zvîncă, Noi descoperiri funerare de pe teritoriul localității Enisala (com. Sarichioi, jud. Tulcea), Peuce, S.N., 3-4, p. 317-330;

Suceveanu 1973 - Al. Suceveanu, Un mormânt din secolul XI e.n. la Histria, SCIV, 24, 1973, 3, p. 495-502;

Şantierul... - Şantierul arheologic Garvăn (Dinogetia), SCIV, 5, 1954, 1-2, p. 161-197 (în colaborare);

Ştefan et alii 1955 - Gh. Ştefan, I. Barnea, B. Mitrea, Maria Chişvaşi, P. Diaconu, E. Comşa, Şt. Constantinescu, Şantierul arheologic Garvăn-Dinogetia (r. Măcin, reg. Galați), SCIV, 6, 1955, 3-4, p. 713-752;

Ştefan et alii 1967 - Gh. Ştefan, I. Barnea, Maria Comşa, E. Comşa, Dinogetia I. Aşezarea feudală timpurie de la Bisericuța-Garvăn, Bucureşti, 1967;

Vasiliu 1980a - I. Vasiliu, Observații cu privire la mormintele de inhumație de la Troesmis, Peuce, 8, 1980, p. 218-229;

Vasiliu 1980b - I. Vasiliu, Cercetările arheologice întreprinse în cimitirul feudal-timpuriu (secolele XIXII) de la Isaccea, MCA (a XIV-a sesiune anuală de rapoarte), Tulcea, 1980, p. 480-487;

Vasiliu 1984 - I. Vasiliu, Cimitirul feudal-timpuriu de la Isaccea, Peuce, 9, 1984, p. 107-141;

Vasiliu 1991 - I. Vasiliu, Săpăturile de la Dinogetia (1982-1985), Peuce, 10, 1991, vol. I, p. 371-391, vol. II, p. 341-357;

Vasiliu 1995 - I. Vasiliu, Cimitirul medieval de la Isaccea. Biserica Sf. Gheorghe, Peuce, 11, 1995, p. 373-409;

Vasiliu 1996 - I. Vasiliu, Obiecte de podoabă şi accesorii vestimentare medievale din colecțiile muzeului de arheologie din Tulcea, Peuce, 12, 1996, p. 225-242;

Văjarova 1975 - Jivka Văjarova, Zum problem der Glasproduktion im Mittelalterlichen Bulgarien (8-10 Jh.), în Verre medieval aux Balkans ( $V^{e}-X V^{e}$ s.), Belgrad, 1975;

Văjarova 1976 - Jivka Văjarova, Slavjani i Prabălgari (po danni na nekropolite ot VI-XI v. na teritorijata na Bălgarija), Sofia, 1976, p. 5-30;

Văjarova 1981 - Jivka Văjarova, Dvuobrjaden eziceski nekropol kraj s. Bdinci, Tolbuchinski okrăg, IzvestijaVarna, 17 (32), 1981, p. 77-109; 
Văjarova 1986 - Jivka Văjarova, Srednovekovnoto selişte, s. Garvăn, Silistrenski okrăg, VI-XI v., Sofia, 1986;

Zirra 1963 - Vl. Zirra, Dvuobrjadovîi mogylnik rannefeodalnîi epohj v Kapul Vijlor - Istrja, Dacia, NS, 7, 1963, p. 355-412;

\section{BIBLIOGRAFIE (PENTRU STUDIUL ANTROPOLOGIC):}

Acsádi, Nemeskéry 1970 - Acsádi, Gy., Nemeskéry, J., History of human life span and mortality, Académiai Kiadó, Budapest, 1970;

Brothwell 1981 - D. R. Brothwell, Digging up bones, $3^{\text {rd }}$ edition, Cornell University Press, Ithaca, New York, 1981;

Maximilian 1962 - C. Maximilian, Sărata Monteoru- Studiu antropologic, Bucureşti, 1962;

Necrasov et alii 1959 - Olga Necrasov, M. Cristescu, C. Maximilian, D. Nicolăescu-Plopşor, Studiu antropologic al scheletelor neolitice, descoperite în cimitirul preistoric de la Cernavodă, în Probleme de Antropologie, vol. IV, Bucureşti, 1959, p. 21-45;

Mirițoiu 1992 - N. Mirițoiu, Porotic hyperostosis in the free dacians' necropolis at Poeneşti (Vaslui county): congenital hemolytic anemia or iron deficiency anemia?, Annuaire roumain d'Anthropologie, 29, 1992, p. 3-12;

Olivier 1960 - G. Olivier, Pratique anthropologique, Vigot Frères, Éditeurs, 23, Rue de l'Ecole de Médicine, 23- Paris- VI ${ }^{\mathrm{e}}, 1960$;

Rösing 1988 — F. W. Rösing, Körperhöhenrekonstruktion aus skelettmaßen, în Anthropologie, Handbuch der vergleichenden biologie des menschen, Gustav Fischer Verlag, Stuttgart-New York, 1988, p. 586-599;

Ubelaker 1978 - D. H. Ubelaker, Human skeletal remains, Manuals on archaeology, $2^{\text {nd }}$ edition, Washington, 1978.

\section{ABREVIERI}

CCA - Cronica cercetărilor arheologice

Dacia — Dacia, Nouvelle Serie, Revue d'Archéologie et d'Histoire Ancienne, Bucarest

Dobrudja - Dobrudja, Sbornik Istoriceskij Muzei v Dobrič i Silistra

Godişnik - Godişnik na Sofijskija Universitet „Sv. Kliment Ochridski”, Istoriceski fakultet (- spetzialnost archeologhija), Sofia

Hierasus - Hierasus. Anuarul Muzeului județean Botoşani

IzvestijaVarna - Izvestija na Narodnija Muzej, Varna

MCA - Materiale şi cercetări arheologice

Peuce - Peuce, Studii şi cercetări de istorie şi arheologie, Institutul de Cercetări Eco-Muzeale, Tulcea

Pontica - Pontica, Studii şi materiale de istorie, arheologie şi muzeografie, Muzeul de Istorie Naţională şi Arheologie, Constanța

SCIV(A) - Studii şi cercetări de istorie veche (şi arheologie), Bucureşti

SMMIM - Studii şi materiale de muzeografie şi istorie militară, Bucureşti

\section{EXPLICATION DES FIGURES}

Fig. 1. Vues aériennes du village Nufăru

Fig. 2. Le plan du village Nufăru: la répartition des fouilles archéologiques

Fig. 3. Le plan du village Nufăru: la répartition des découvertes funéraires

Fig. 4. Tombes découvertes dans la rue Bisericii (catalogue, les tombes 34, 37-38) 
Fig. 5. Tombes découvertes dans la rue Bisericii (catalogue, les tombes 39, 41, 44)

Fig. 6. Tombes découvertes dans la rue Bisericii: vues générales de la fouille du côté S (1-2); catalogue, les tombes 34 (3); 37 (4); $38(5) ; 39$ (6); 40 (7); 44 (8)

Fig. 7. Tombes découvertes dans la rue Turnului /Ecole; plan de la section; catalogue, les tombes 3-14

Fig. 8. Tombes découvertes dans la rue Turnului /Ecole; vues générale de la fouille du côté $S$ (1) et du côté N (2); catalogue, les tombes 5 (3); 6 (4); 7 (5). Tombe découverte sur la propriété Popa - catalogue, la tombe 17 (6)

Fig. 9. Tombes découvertes dans la rue Turnului, Dispensaire (catalogue, les tombes 15-16) et sur la propriété Popa (catalogue, la tombe 17)

Fig. 10. Tombes découvertes sur la propriété Ducica; plan de la section, catalogue, les tombes 18-23

Fig. 11. Tombes découvertes sur la propriété Ducica; vues générales de la fouille du côté $\mathrm{O}$ (1) et du côté $\mathrm{N}(2)$; catalogue, les tombes 18 (3); 21 (4); 19 (5-6); 20 (7); 20, 22 (8)

Fig. 12. Tombes découvertes sur la propriété Drăgan; plan de la section (d'après Mănucu-Adameşteanu 1983); catalogue, les tombes $45-57$

Fig. 13. Tombes découvertes sur la propriété Drăgan; vues générales de la fouille du côté E (1-2); catalogue, les tombes 47 (3); 48 (4); 49 (5); 50 (6); 53-54 (7); 57 (8)

Fig. 14. Tombes découvertes dans la rue Bisericii, au S du mur d'enceinte sud (catalogue, les tombes 9597)

Fig. 15. Tombes découvertes dans la rue Rapsodiei (catalogue, la tombe 125) et Bisericii, au $\mathrm{S}$ du mur d'enceinte sud (catalogue, les tombes 99-100)

Fig. 16. Tombes découvertes dans la rue Bisericii, sur les côtés du mur d'enceinte sud (catalogue, les tombes 101-102; 108-109)

Fig. 17. Tombes découvertes dans la rue Bisericii, sur les côtés du mur d'enceinte sud — catalogue, les tombes 99 (1); 100 (2); 101-102 (3); 108-109 (4). Tombe découverte dans la rue Rapsodiei — catalogue, la tombe $125(5-6)$

Fig. 18. Tombe découverte dans les rues C-tin Dobrogeanu Gherea (catalogue, les tombes 25-26) et Bisericii (catalogues, les tombes 42, 63-64, 68)

Fig. 19. Tombes découvertes dans la rue Bisericii, la cour du Foyer culturel; vues générales de la fouille du côté $E$ (1) et du côté O (2); catalogue, les tombes 74-75 (3); 74 (4); 75 (5); 76 (6); 78 (7); 79 (8)

Fig. 20. Tombes découvertes dans la rue Bisericii, zone du Foyer culturel (catalogue, les tombes 80-86)

Fig. 21. Tombes découvertes dans la rue Bisericii, zone du Foyer culturel; vue générale de la fouille du côté E (1); catalogue, les tombes 80 (2); 82, 84 (3); 82 (4); 85 (5); 83 (6)

Fig. 22. Tombes découvertes dans les rues Bisericii — catalogue, les tombes 86 (1); 63 (2); 68 (4); 64 (4) et C-tin Dobrogeanu Gherea - catalogue, les tombes 25-26 (5)

Fig. 23. Tombes découvertes dans les rues Aurel Vlaicu (catalogue, la tombe 134) et Miron Costin (catalogue, les tombes 135-137)

Fig. 24. Tombes découvertes dans la rue Miron Costin (catalogue, les tombes 138-141)

Fig. 25. Tombes découvertes dans la rue Miron Costin (catalogue, les tombes 142-146)

Fig. 26. Tombes découvertes dans la rue Miron Costin; vue générale de la fouille du côté $N$ (1); catalogue, les tombes 135 (2); 136-137 (3); 138 (4); 139 (5); 140 (6); 141 (7); 142 (8)

Fig. 27. Tombes découvertes dans les rues Miron Costin — catalogue, les tombes 143 (1); 145 (2); 146 (3) et Aurel Vlaicu - catalogue, la tombe 133 (4)

Fig. 28. Pièces du mobilier funéraire: catalogue, les tombes 48 (1, 6); 21 (2); 101 (3); 28-29 (4); 67 (5); $57(7)$

Fig. 29. Pièces du mobilier funéraire: catalogue, les tombes 78 (1, 3-4); 75 (2); 26 (5)

Fig. 30. Détails anthropologiques relevés par les complexes funéraires analysés: catalogue, les tombes 2 (1); 27 (2); 30 (3); $44(4) ; 56(5), 57$ (6) 